Marquette University

e-Publications@Marquette

Marquette University Press Publications

1957

A History of Slavic Studies in the United States

Clarence A. Manning

Follow this and additional works at: https://epublications.marquette.edu/mupress-book 
A History of Slavic Studies in the United States 


\title{
A History of Slavic Studies in the United States
}

\author{
Clarence A. Manning \\ Associate Professor of Slavic Languages \\ Columbia University
}

The Marquette University Press

MilwaUKeE 1957 Wisconsin 
Marquette Slavic Studies are published under the direction of the Slavic Institute of Marquette University.

\author{
Edited by Roman SmaL-Stocki \\ Advisory Board Cyru E. SMIth \\ Alfred SOKOLNicki \\ Christopher Spalatin
}

The views expressed in the Marquette Slavic Studies are those of their authors, and are not to be construed as representing the point of view of the Slavic Institute.

Library of Congress Catalog Card Number: 57-11742

(C)Copyright, 1957, Marquette University Press, Milwaukee, Wis. 


\section{Contents}

INTRODUCTION

vii

Chapter 1 The Slavs in America 1

$\begin{array}{llll}\text { Chapter } 2 & \text { Mass ImMigration } & 9\end{array}$

Chapter 3 Slavic Studies in the Nineteenth Century 17

Chapter 4 The Beginning of Formal Study 25

Chapter 5 Slavic Efforts Before World War I 36

$\begin{array}{llll}\text { Chapter } 6 & \text { Frом } 1914 \text { то } 1939 & 44\end{array}$

$\begin{array}{lll}\text { Chapter } & 7 & \text { Slavic Studies Since } 1939\end{array}$

Chapter 8 The Future Tasks of Slavic and East European Studies 83 Integration in American consciousness. The divisions of the area. Undergraduate courses. Language instruction. Graduate work. Area studies. Summary.

$\begin{array}{ll}\text { BIBLIOGRAPHY } & 109\end{array}$

$\begin{array}{ll}\text { INDEX } & 114\end{array}$ 


\section{Introduction}

Prepartng an adequate history of Slavic and East European studies in the United States is not an easy task. Much of the pertinent material has never been collected. Where it has been brought together, it has never been adequately evaluated or put in its proper setting against the general American cultural and educational development. Any attempt at a synthesis of the situation must then be highly tentative, subject to correction and amplification.

In the formal sense, studies and courses in the Slavic languages, cultures and history began to appear in American colleges and universities at the end of the nineteenth century, largely through individual interest and effort. Until World War I, these courses developed slowly and aroused little interest. We can say the same of the formation of libraries and of collections of other materials. If then we should treat the history of Slavic studies in this narrow sense, we would secure a creditable but small list of courses and publications multiplying on a large scale only since World War II began.

Yet, this picture would be incomplete. It fails to consider certain factors which have greatly influenced American life and thinking and which will in the future exert still more influence. It likewise ignores significant achievements of earlier periods. It ignores certain individuals who, though only tenuously connected with universities and colleges, influenced the course of events. It ignores also that one phenomenon that sharply differentiates the scope of Slavic and East European studies in the United States from such studies anywhere else in the world. That is the presence in the United States of millions of Slavic immigrants and their descendants. These have played a hitherto unrecognized part in the country's development and at the same time have given it some unusual aspects.

Slavic studies in the United States can never be as important as in those countries where the dominant language is Slavic, and where a knowledge of the language is a necessity for daily life. There the Slavic tradition, even under external pressure, is still alive. It expresses itself in every form of culture, every study of the local environment, natural or artificial. Thus, from 
late in the eighteenth century, the universities of AustriaHungary, especially the University of Vienna, and those in such Slavic centers as Prague, Krakow, Lwow and Zagreb developed flourishing centers of Slavic studies. The universities in the Russian Empire also concentrated not only on Russian, but on all the other tongues. It was in these countries that Slavic languages came earliest and most completely into their own, as they later did in the independent Slavic countries.

Yet Slavic and East European studies are not in the same position as they were in past decades in Germany, France and the British Isles. There, they were definitely intellectual disciplines which might find practical use in certain governmental and educational posts but which were of interest only to a small number of specialists. In those countries there were learned professors of Slavic. This is especially true of Germany and France where relatively large groups of outstanding Slavs, chiefly of the educated, professional and political classes, were able to influence higher level thought in those countries. Few ordinary Slavs appeared in either country. Those who did were mostly migratory workers who did not take root in their new environment, and exercised little influence.

That is not true in the United States. There were before World War I a small number of outstanding representatives of the Slavic nations, free or not. But the United States was also brought face to face with the immigration of millions of Slavic workmen and peasants. These brought little material or consciously intellectual baggage to the country but took root here and, under the leadership which they developed in the United States, have played a steadily increasing role in American life. They and their descendants of the second and third generations are not a negligible force. Their children and grandchildren may have lost a certain facility in the use of their mother tongues but they have retained qualities, knowledge and traditions which are vital to the United States today and which cannot fail to have a far-reaching effect upon the entire world in the future.

We cannot then speak of Slavic studies merely in the narrow sense of the word. We must take into account these other factors which are rapidly becoming tangible elements in all of American life. In this sense we must consider Slavic and East 
European studies to include those means other than political propaganda which have led to the present American knowledge of the Slavic world, a knowledge with some striking insights and some equally amazing gaps.

The present survey is an attempt to handle all aspects of the growing awareness of the Slavs by the American people and the American educational system. Yet we can hardly do this without a brief survey of the way in which the Slavs appeared on the American scene and the methods by which they have come to assume their present position. The complete history of this has never been written though we do have a fair outline of the various stages of the movement. 


\section{CHAPTER 1}

\section{THE SLAVS IN AMERICA}

WE HAVE No RECORDS of the arrival in what is now the United States of the first Slavic nationals. We don't know from where they came or where they settled. But it seems certain that at an early date Slavs appeared in all of the various streams of colonization though primarily as individuals. We must remember that it was not until the nineteenth century that the world became seriously interested in the nationality and language of a person. The medieval period had thought only in terms of allegiance to a given monarch or to some supernational state which embraced persons of many tongues and origins, united in a common loyalty.

This held true for the first two centuries of American settlement and we always have to take it into account. It may be well to glance briefly, then, at the political situation in the Slavic lands, from the discovery of America through the next century.

Christopher Columbus discovered the New World less than a half century after the fall of Constantinople to the Turks and the liberation of Moscow from the Tatar yoke. Europe was filled then as now with homeless people, the Christians of the Byzantine Empire and of the Balkan Christian states, preferring the hardships of a wandering life to existence under the Mohammedan Turks. The armed forces of all countries were filled with adventurers who had been driven from their homes and were glad to fight as mercenaries.

For example, there were Greek soldiers in the armies of Francisco de Pizarro in his conquest of Peru in 1532. Later these same men took sides with Diego de Almagro in his revolt against Pizarro and made for him the first cannon cast in the New World.' 'This intermixture of nationalities continued throughout the era of the discovery and the ensuing decades. This was the height of the Spanish power and it was under the flag of Spain

${ }^{1}$ W. H. Prescott, Conquest of Peru, Philadelphia, (1902), II, p. 199. 
that men of all nationalities, especially from the Mediterranean area, went to serve.

At this time, the most powerful Slavic state was the Polish Republic, the Rzeczpospolita Polska. Yet this was far more than ethnographic Poland. It took in almost all Ukrainian and Byelorussian lands as well as ethnographic Lithuania and Latvia and a considerable part of eastern Germany. It maintained the closest connections with the Danubian principalities and even Hungary. Thus, a person known as a Pole could very easily have been one of several Slavic and even non-Slavic nationalities.

The Czechs formed the nucleus of the Kingdom of Bohemia, itself a subsidiary of the Hapsburg domains, the Holy Roman Empire (which, to use the words of Voltaire, was already ceasing to be either Holy, Roman or an Empire). The Slovaks and the Carpathian Ukrainians were under the Crown of St. Stephen of Hungary as were the Croats, while the Slovenes were more particularly connected with Austria. Yet again, the lands of the Crown of St. Stephen were also part of the Empire.

Thus the only Slavs not included either in the Ottoman and Hapsburg empires or in Poland were the Muscovite Russians. At this period few of them thought of crossing the boundaries of their western neighbors. Those who left their original homes traveled eastward and by the middle of the seventeenth century had reached the Pacific ocean and were poised to cross the north Pacific at its narrowest point.

We must keep these facts in mind when we think of the early Slavic immigration to the United States. This jumble of nationalities and states was still more confused by the fact that the overwhelming majority of the educated Slavic population used one of the three international languages of the day. The Roman Catholics used Latin, the Orthodox employed either Church Slavic or Greek, and these "higher" tongues supplemented and in large part replaced the vernaculars in legal and historical records. This was a period of religious turmoil as well, beginning with the Hussite wars in Bohemia. These were continued by the Protestant Reformation touched off by Martin Luther and the Counter-Reformation under the leadership of the Jesuits. At the same time, the new Protestantism and the older Latin Rite were spreading among the Orthodox Slavs and the situation was still further complicated by the Union of Brest in 1594 which formed the so-called Uniat Church or Catholic Church of the Eastern Rite. 
Each of these religious disputes, with the political consequences that they involved, added to the number of displaced persons. The adherents of every religion found shelter with their friends in any of the countries of Western Europe-England, France, Germany, Italy, Spain and Holland. These were added to the number willing to risk anything to secure a new home. This was the background of the early colonization efforts in America.

The Spanish settlements in the southwest are less easily discussed. There can be no doubt that the leaders of the great religious orders that spread through California and New Mexico were of Spanish birth but there is considerable evidence to show that some of their subordinates were probably of Slavic origin. At least they seemed familiar with the peculiarities of Orthodox iconography. The Spanish mission in Santa Barbara, California, displays the Eastern form crucifix. Many of the wood paintings of saints in New Mexico superficially resemble crude icons. Yet little has been done to trace the early lives of the monks who worked in these missions. It would certainly not be surprising to find that some had made their way to the Spanish centers of the Franciscans and Dominicans from the disturbed area of Eastern Europe. ${ }^{2}$

We are on far surer ground when we come to the colonies established by the English along the Atlantic coast. In 1610, the Virginia Company sent to Jamestown, with Lord de la Warr, a group of Polish gentlemen as workmen. These were apparently refugees in England from one of the many upheavals in the Rzeczpospolita. Their names appear in Anglicized forms and since we have no information about their experiences before they reached England, many of them have been claimed by the Poles, Ukrainians, and the other peoples included in the Polish state. ${ }^{3}$

The same situation prevailed in New Netherlands. There can be no doubt that some of the settlers in the new Dutch colony were Slavs. Thus for a long while, the name of the Zeboroskit family, one of the early settlers, was written in Jersey Dutch. The family is proud of its Polish origin but again like so many,

2 Professor Otokar Vocadlo of the University of Bratislava visited in 1929 some of the missions and came to the conclusion that they included Slavic monks.

${ }^{3}$ M. Haiman, Polish Past in America, 1608-1865 (Chicago: Polish Roman Catholic Union).

4 J. D. Prince, "The Jersey Dutch Dialect," Dialect Notes, III, (1910), pp. 459-484. The usual modern form is "Zabriskie." 
it also has been clained by the Ukrainians. Another Slav of this period is Augustine Herrman, a skilled surveyor from Prague. He apparently went first to Virginia, then moved northward to New Amsterdam and later founded Bohemia Manor in Maryland. Efforts have been made by both the Czechs and the Germans to prove that he was of their origin but what proof there is favors the Czechs. ${ }^{5}$ Many other families, such as the Roosevelts, can trace their origin to the Baltic states but leave us to decide from which particular group the original ancestor came.

A still more tangled situation arose in the early colony of Delaware, while it was still New Sweden. The Swedes eliminated the first Dutch settlement around Fort Casimir and then in 1641 founded their own Fort Christina and sent over a population of Swedes, Germans and Finns, and all this at a time when the Poles and the Swedes were conducting their own warfare behind the shelter of the Thirty Years War. At the same time the Swedes were trying to make the Baltic a Swedish lake and their representatives were deeply involved in negotiations with the Zaporozhian Kozaks who were in an almost constant state of revolt against Poland. The Swedes then ruled both Livonia and Estonia. In view of all this it would have been surprising indeed if there had not been Slavs in the colony of New Sweden, the area in which the traditionally American form of the log cabin seems to have originated, a form reminiscent of the architecture of the East Baltic Slavs. The evidence for New England is less clear, though we know that the authorities of the new Harvard College seriously thought of inviting the distinguished Czech educator, Jan Amos Comenius (Komensky) to serve as the first president, in 1630. However, nothing came of it. ${ }^{6}$

In the eighteenth century there is the same uncertainty. In 1741 a group of the Unitas Fratrum (the Bohemian Brethren) from Bohemia and Moravia, were led by Count Zinzendorf to a settlement in Bethlehem, Pennsylvania. It is at least possible that some of these settlers spoke Czech as well as German. If they did, it would explain more clearly the interest in the community that was taken during the American Revolution by General

5 Thomas Capek, Augustin Herrman zakladatel Bohemia Manor r. 1660 a autor mapy statu Virginie a Marylandu. (Praha: Vytiskla statni tiskarna, 1930); Dictionary of American Biography (New York: Charles Scribner's Sons, 1932), VIII, p. 592.

${ }^{6}$ Robert J. Kerner, Bohemia in the Eighteenth Century (New York: Macmillan, I932), p. 315 . 
Kasimierz Pulaski, who seems to have made a point of attending religious services there whenever he could. The architecture of the older buildings further suggests Slavic influence.

The American Revolution brought to the New World another group of Slavs, of whom the best known are the two Polish leaders, Generals Pulaski and Tadeusz Kosciuszko. ${ }^{9}$ Pulaski, already a well-known figure in Poland, brought with him a number of other East Europeans and Slavs who formed a considerable portion of the famous Pulaski Legion. We have also the names of others, such as Count Bienowski and Colonel Michael Kovach, an Hungarian, a member of the Legion who was killed at Charleston, South Carolina, in 1779. Most of the Legion's survivors stayed in the new country.

Another possible source for inspiring Slavs, and especially Poles, to come to America was the career of Major General Charles Lee, ${ }^{\theta}$ of the American Army. He had once been in command of the Cadet School in Warsaw founded by King Stanislaw Poniatowski. In addition to that, most of the French troops who served in America had previously been on duty in western Poland supporting the Saxon claims to the throne and helping the Poles oppose Russian domination. There is no way of knowing whether or not this force had received Slavic recruits during its term of duty there. The services of both Pulaski and Kosciuszko, and the later return of Kosciuszko to the United States in 1797, built up considerable interest for Poland in the United States. This continued for nearly a half century, leading to a fair amount of immigration from the former Polish state, especially after the Polish Revolt of 1831.

Moreover, American newspapers of the time published long accounts of events in Europe. Thus, in 1733 John Peter Zenger included in the New York Weekly Journal an account of the efforts of Stanislaw Leszczynski to secure the throne of Poland. Numerous similar examples could be cited. However, no organized interest in Slavic lands and peoples developed.

Little is heard of Russians at this period, although American representatives had appeared in St. Petersburg during the Revolution and the Tsars, in the early $1800^{\prime}$ s, began to send diplo-

- Clarence Manning, Soldier of Liberty, Casimir Pulaski (New York: Philosophical Library, 1945), p. 253.

- M. Haiman, Poland and the American Revolutionary War (Chicago: Polish Roman Catholic Union, 1932 ).

${ }^{9}$ For data on Major General Charles Lee, see ibid., p. 4. 
matic representatives to Washington. Prince Dimitry Golitsyn, ${ }^{10}$ a member of a socially prominent Russian family, was the first Roman Catholic priest to be fully trained and ordained by Bishop Carroll in the United States. He continued until the end of his life to be one of the leading Catholic priests in Pennsylvania, and maintained contact with the Russian Ministers in Washington. We also know that in 1800 , Kutusoff mantles and bonnets were very popular in New York society. ${ }^{11}$

Until 1848, the Slavs who came to the United States came either as individual travelers or as individual immigrants, perhaps drawn in the train of some more prominent compatriot. There are several interesting accounts of this period, in Polish, such as those by Juljusz Ursin Niemciewicz who came with Kosciuszko in 1797 and remained in the country for several years. He visited Boston around 1799 and his diary mentions a Polish Unitarian library, the Bibliotheca Fratrum Polonorum, in Harvard of which nothing is now known. ${ }^{12}$

The situation was different in the Pacific northwest. ${ }^{13}$ The Russians during the seventeenth and eighteenth centuries reached the Sea of Okhotsk and Kamchatka in their eastward advance and began to push into the north Pacific in quest for furs. Late in the century they started to establish more or less temporary trading posts on the Aleutian Islands. In 1783, Grigory Shelikov established a more permanent center at Kodiak. This center of Russian influence was later transferred south to St. Michael on the site of the present Sitka in 1800. (The ablest Russian governor, Aleksander Baranov, went further. In 1811 he sent his most trusted assistant, Ivan Kuskov, to establish a Russian trading post at Fort Ross, not far from San Francisco). Shelikov had founded the Russian-American Company to exploit these new lands, and his talented successor, Nikolay Rezanov, visited the New World in 1805, dreaming of controlling the entire Pacific coast, including the Spanish settlements in California with San Francisco as their head. On his return across Siberia he died at Irkutsk as the result of a fall from his horse and his

${ }^{10}$ For data on Prince Gallitzin (Golitsyn), cf. Dictionary of American Biogtaphy (New York: Charles Scribner's Sons 1932), VIII, p. 113: D. Sargent: Mitri, The Story of Prince Demitrius Augustine Gallitzin, 17701840 (New York: Longmans, Green and Co, lnc., 1945).

11 H. C. Brown, Valentine's Manual of the City of New York, New Series I (New York: Valentine Co, 1916), p. 24.

12 Haiman, op, cit., p. 178.

13 Clarence Manning, Russian Influence in Early America (New York: Library Publisher, 1953), pp. 17-142. 
dreams largely perished with him, although later the Russians did try to seize the Hawaiian Islands and make the north Pacific a Russian lake.

Fortunately for the Americans, the Russian settlements were poorly supported from St. Petersburg and the intricacies of Russian law left Baranov and his successor without the necessary supplies and they were compelled to indulge in illegal trade with the British. Boston merchants also carried to Kodiak and Sitka the goods which the Russian-American Company had neglected to send.

Strangely enough, the Russians failed to cross the coastal mountains either in Alaska or further to the south. They contented themselves with the hunting of marine animals, especially the sea otter, sending the skins back to Siberia for Asiatic distribution. They apparently did not realize that the American continent could be crossed by land, a peculiar oversight when we remember their rapid crossing of the whole of Asia. Rezanov had hoped to make Kodiak a center of Russian culture. He had come to Russian America by sea from St. Petersburg and brought with him a large library of books for an academy which he proposed to establish. Apparently Shelikov had spread excessive stories of the Russian achievements, for Kodiak was only a wretched frontier village and not an embryonic metropolis, Slava Rossii, as he boasted. Rezanov's collection remained in Kodiak until its destruction by fire on July 18, 1943.

The Russian Orthodox Church also sent a mission to the colony. The monks, largely from Valamo, were devoted men and at least one was a martyr. The greatest of the Russian clergy was Ivan Venyaminov, later Archbishop Innokenty, Metropolitan of Moscow and one of the great figures of the Russian Church. This mission converted the majority of the Aleuts and Eskimos in the neighborhood and the Russian language was long the common speech on most of the Aleutian Islands.

Russian expansion thus had begun to take shape seriously at about the same time the Americans began to push westward. After buying the Louisiana Territory from France in 1803, President Thomas Jefferson sent an expedition under Meriwether Lewis and William Clark to explore the northwest. In 1806 the expedition reached the mouth of the Columbia River. Then followed the settlement of Astoria by agents of the American 
fur trader, John Jacob Astor. By the time the Russians were ready to advance to the south, the Americans were established in the center of the area and the Russian colonies never formed a solid belt on the west coast. For some reason the Russians did not try to eliminate the Americans and the southern settlements began to wither away from inability to expand. In 1841, Fort Ross was sold to a group of Americans and the Russians withdrew northward.

The lively trade between Sitka and Boston was interrupted by the War of 1812 and when peace came, commerce was further hindered by Russian efforts to impose trade restrictions that were unacceptable to the Americans. These came at the same time as the revolutions and declarations of independence of the Spanish colonies and the adherence of Tsar Alexander I to the Holy Alliance to aid Spain in recovering them. The Russian efforts at controlling the north Pacific and the American sympathy for the Spanish colonies led to the proclamation of the Monroe Doctrine in 1823 which doomed European expansion in the New World. Both President Monroe and his Secretary of State, John Quincy Adams, had held diplomatic posts in Russia and were aware of the differences between the Russian and American points of view.

The Monroe Doctrine and the settlement of the northwest determined the fate of Russian America. It was blocked to the south by the United States and the British settlements in the Canadian West. In 1867, Russia realized the hopelessness of its position and sold the territory now known as Alaska to the United States. The Russians then established their bishopric in San Francisco but during the next years the Russian colony in the far west remained an isolated group and it was only toward the end of the century that it merged with the general Slavic immigration.

This, then, is the first phase of Slavic contact with the New World. Relatively little imprint was left on American life, although we must not undervalue certain ideas that did pass into the young republic. They were the result of individual effort rather than organized or mass movements which came later. 


\section{MASS IMMIGRATION}

As THE MIDDLE OF THE CENTURY approached the situation began to change radically. There came a marked improvement in the accommodations and regularity of the transAtlantic ships and contacts between North America and Europe began to multiply.

Then came the Spring of the Nations, the year 1848, with the efforts of the Germans and the peoples of Austria-Hungary to put an end to the prevailing absolutism. This movement failed but it led a large number of Germans who had supported the Frankfort General Assembly to leave their native land and to seek refuge in the United States. Most of them drifted west, settling in many of the Central States and the Middle West. They took up free land and settled down to become prosperous farmers. The rumors of their success in adapting themselves to their new environment spread beyond Germany and fired the resolution of other discontented peoples.

The first to respond on any large scale were the Czechs. They began to come in thousands, also tending toward the Middle West and settling on the new frontiers which had been pushed westward by the coming of the Germans. They soon began to form extensive colonies in the still sparsely settled areas of Nebraska, Iowa, and other states until the coming of the American Civil War, which briefly checked the movement. In their new homes, and in small communities, they formed a large segment of the population. They endeavored to transplant their old traditions and mode of life to America and to establish their own institutions, making changes only as American law and environment dictated. ${ }^{14}$

The Poles were the next Slavic people to follow. The earliest immigrants were, as we might expect, from Austrian Poland but after the failure of the urprising of 1863, refugees from

14 Thomas Capek, History of the Bohemians (Czechs) in America (Chicago, 1920); Rose Rosicky, A History of Czechs (Bohemians) in Nebras$k a$ (Omaha; Czech Historical Society of Nebraska, 1929), p. 33 ff. 
Russian Poland and the area under German control began to flow in. The earliest immigrants, like the first Czechs, moved west but after the Civil War the great American industrial expansion began and the majority of later immigrants were attracted by the possibilities for work in the mines and factories which were being built, especially in Pennsylvania. The movement for immigration was sponsored not only by the employers, who desired a constant supply of unskilled and cheap labor, but also by the steamship companies which sent their agents through the European villages and painted in glowing terms the possibilities of advancement and of wealth in the United States.

Their blandishments did not fall upon empty ears in the more backward and underprivileged areas. In a steadily increasing stream, there began to come to the United States, Slovaks, Ukrainians from Galicia and the Carpathian area, Croats, and, to a lesser degree, Serbs. There was even a small settlement of Lusatian Sorbs in Texas. This process continued until the beginning of World War I.

The immigrant ranks included a certain number of educated people but these were to a large degree interested in some form of art, attracted by the opportunities for practicing their talents in the United States. The political immigrants were relatively few for since they had hopes of affecting conditions in their homelands they preferred to find temporary refuge in some European country.

The majority of immigrants came from those strata which had become accustomed to leaving their homes as migratory and seasonal workers. Most were scarcely literate and were little aware of the cultural progress that was going on in their homelands. At first they came merely in the hope of saving up enough money to return and live with more comfort in their native villages. But it was not long before they either despaired of this or were attracted to the American mode of living and sent for their wives and families. Many of these early arrivals had little national consciousness and the Slovaks and Ukrainians in particular reflected the conditions prevailing in the last quarter of the nineteenth century.

The change from the hard but traditional life of the Slavic village to the confusion and grimness of the American mining or factory town was a disagreeable shock to many of these immigrants, for it was primarily the agricultural population of 
Eastern Europe that poured into the American factories and mines. The newcomers were exploited everywhere and with their ignorance of English were at a disadvantage in competing with their neighbors.

However, they rapidly adapted themselves to their changed environment. They began to form various kinds of associations for their own advantage and leaders of their own groups began to appear. Some of these were unscrupulous men who learned some English and didn't blush to drain money from their less fortunate comrades. But the number of those who seriously worked for the good of the immigration steadily grew and finally eliminated, to a large extent, the more greedy and grasping pseudo-leaders. ${ }^{15}$

The Slavic communities in the United States owe much to the priests who came to serve in the churches which they established in all the Slavic centers. Some of them had come with the authorization of their superiors in the Old World. Others simply followed the outflow from their villages and arrived in America with little more knowledge of conditions than their flocks. Their lack of familiarity with the legal conditions governing church property in the United States involved them in many difficulties. Even the immigrant Roman Catholic priests serving the Poles and Slovaks could not, at first, easily fit themselves into the framework of their Church in the United States and through misunderstandings they often got into controversies with the Roman Catholic hierarchy here, consisting mainly of Irish and Germans, and all too often they were tempted to declare their complete independence and make needless issues over extra-ritual customs and parish organization. The situation was even worse for the Catholic priests of the Eastern Rite (the Uniats) who ministered to the Ukrainians from Galicia and the Carpathians. These people insisted at first upon a married clergy and since they often came without proper credentials, they were looked at askance by the hierarchy who had no experience or personal knowledge of this Rite. In addition, many of the priests from the Carpathians had been under strong Hungarian influence at home and found it difficult to serve

15 There is a large literature on various facets of this mass immigration: T. Capek, The History of the Bohemians (Czechs) in America; the works of various Polish sociologists; Propamyatna Knyha (Jubilee Book of the Ukrainian National Association), (Jersey City, N.J.: Svaboda Press, 1936); M. I. Pupin, From Immigrant to Inventor (New York: Chas. Scribner's Sons, 1923). 
their flocks adequately in the New World. The Russian Orthodox were somewhat better off, especially after the seat of the Archbishopric was moved to New York. But, there again, many parishes indulged in almost continuous appeals to the civil authority against the administration of the church. However, by the end of World War I, most misunderstandings had been eliminated on all sides and the way was open for smooth and steady development.

Yet it was the priests who became the first community leaders to guide the immigrants to a new and better life in which they retained as much as possible of their old traditions.

They and the more experienced lay leaders played a great role in the organization of the Slavs into fraternal societies, which had risen in the United States even before the Revolution and since then had grown steadily and found a place both in American life and American law. On the payment of small sums they provided protection to their members, payments in case of death or inability to work and, in some cases other assistance.

The value of this system was early recognized by the Slavic leaders. At first the societies were small and purely local but in time the individual groups tended to unite into central organizations which acquired larger and larger capital resources. These societies, whether directly connected with churches or not, gradually came to form a distinctive feature of SlavicAmerican life. Today there is no Slavic group which does not have one or more such organization of national significance. Among the leaders are the Czechoslovak National Alliance, the Polish National Alliance, the Ukrainian National Association, the Serb National Federation, the Polish Roman Catholic Union, the Ukrainian Workingmen's Association, the Ukrainian Providence Association, the Croatian National Alliance. They possess large reserve funds and are leaders in financial, social, political and cultural work.

Furthermore, as we shall see, it is out of these large, freely organized, fraternal organizations, with or without church support, that certain forms of Slavic scholarship have developed in the United States. This was inconsiderable in the beginning but it has grown and improved steadily and is destined to play a very important role in the future, especially in the case of those countries from which there has been an extensive immigration. 
Russian immigration has followed a quite different course. During the nineteenth century, the Russian Empire tried to channel all movement from home areas to Siberia instead of across the ocean. For this purpose, the government appropriated large sums of money and furnished transportation first from the Black Sea ports to the Pacific coast and then later along the Trans-Siberian railroad. As a result, prior to 1908 , almost the entire Russian immigration into the United States was from the non-Russian areas in the northwest. This includes the Finns, the Lithuanians, the Poles and the Jews who began to leave Russia in large numbers in the nineties because of the antiSemitic outbreaks.

The actual Russian population of Russian Alaska had been small. But, during the second half of the nineteenth century, after its sale, a number of Russians drifted across the Pacific Ocean to San Francisco. The seat of the Archbishopric of the Aleutian Islands and North America was moved from Sitka to San Francisco, In 1900, there were enough Russians on the Atlantic coast to warrant Tikhon, later Patriarch of Moscow, moving his episcopal seat to New York. ${ }^{16}$ This was done not only to serve the needs of the Russian Orthodox population but to enable him to exert an influence on the Greeks and other Orthodox who had emigrated to the east coast. About 1905, the difficulties between the Roman Catholic hierarchy and the Catholics of the Eastern Rite made opportune a Russian attempt to bring the Eastern Rite adherents back to Orthodoxy. At the outbreak of World War I the bulk of the Russian Orthodox Church in America consisted of converts from Galicia and the Carpathians. There also had been Russian immigration after the revolutionary disturbances of 1905 , but in 1904 the actual Russian immigration in America was small, far less in numbers than any other Slavic group except the Bulgarians.

By 1914, the Slavic communities in the United States especially the Czechs, the Slovaks and the Poles, were already well organized. These, with their national committees, played a considerable role in securing the independence of their homeland.

${ }^{16}$ Clarence A. Manning, Russian Influence in Early America; also, the following articles on the history and development of Russian institutions -Bishop Leonty, "History of Russian Orthodox Church in America," Russian Orthodox Journal, Vol. XVI, No. 11, 12 (March-Apr, 1943); Vol. XVII, No. 2, 4, 11 (June, Alig. 1944, March 1945); Vol, XVIII, No. 2, 4, 11 (June, Aug. 1945, March 1946); Vol. XIX, No. 4, 6 (Aug., Oct. 1946 ). 
They supported directly and through their American nonSlavic friends the work of Thomas G. Masaryk and Ignace Paderewski. Similarly, Professor Michael I. Pupin stood out as the leader of the Serbs and indeed of all the Yugoslavs. The Ukrainians were less fortunate, for at the moment they had no leader well known to the American public and they encountered the opposition of both Russian and Polish groups, whose nations had dominated Ukraine for centuries.

After World War I, the interrupted stream of immigration again broke through and during the early years it assumed even larger proportions than it had previously. In addition, many White Russians who had fled from the Bolsheviks came to the United States.

The cultural level of the Slavic communities rose rapidly, assisted by better educational opportunities for them both at home and in the immigration. A large number of highly educated Russians had come over and the opening of Washington legations for Poland, Czechoslovakia and Yugoslavia gave the immigrants pride in their own origin and intensified their contact with cultural work being done in their liberated homelands. The, same effect was achieved by the Ukrainian diplomatic mission to Washington under Dr. Bachinsky and later Dr. Luke Myshuha, although unfortunately this did not receive final recognition by the United States.

In 1924, this influx of immigrants was brought to a halt by the passing of American immigration laws which introduced the principle of national quotas and regulated the number of immigrants admitted each year by a ratio based upon previous arrivals. This penalized the Slavs severely for their immigration had been relatively recent and their quotas were reduced almost to the vanishing point. Contrariwise, the peoples of Northern Europe, who had arrived earlier, were assigned quotas which they never filled.

So, from then until World War II, the American Slavic communities remained relatively static in numbers, growing only by natural increases. However, this was also a period when earlier efforts began to bear fruit and Slavic cultural and financial importance increased rapidly. The second generation, educated in American schools, was beginning to produce a new type of leadership. It took its place in the general American cultural, economic and political life with consequent results upon both 
the country as a whole and upon the Slavs. There was increased cooperation between the Slavs and the rest of the American population, a period of growth and development from within. After World War II, the displaced persons from Europe began to enter the United States in large numbers. From 1939 on, there came a surprisingly large number of highly educated persons, largely Poles, who were fleeing from both the Nazis and the Communists. These new arrivals revivified the intellectual and cultural interests of the older immigrants and their descendants and, furthermore, they brought the best traditions of education and scholarship from their homelands.

We can thus divide the growth of Slavic influence into four periods.

I. From the beginning to 1848. During this period, the immigrants arrived as individuals and with few exceptions were absorbed rapidly and almost completely into the main streams of American life.

II. From 1848 to 1924 . This was the period of the mass immigration, largely of unskilled laborers who came to secure the material benefits of life in the United States. Yet it was also the period when the general outlines of Slavic life in America were being sketched, organizational and church affiliations were made, and the immigrant groups were taking root as large units in the United States.

III. From 1924 to 1939. Despite the almost complete lack of immigration, Slavic communities were beginning to attract the attention of the American public. Internally they were completing their adaptation to the American mode of life with far greater success than had seemed possible a few decades before.

IV. Since World War II. Most of the leaders who refused to accept Communism have come to the United States. The outstanding scholars and artists have also come to find refuge. In some instances, it is no exaggeration to say that centers of the higher culture have been transferred to the United States. Simultaneously, the emergence of this country as the spokesman and champion of the free world has awakened far broader classes of the American public to the importance of the Slavs in the modem world and has led to a greater demand for scholarship in those fields which concern the Slavic nations.

There are thus two separate streams of Slavic scholarship in the United States. The one is the normal inclusion of Slavic 
subjects, history, culture and languages into the American universities and colleges. This has been a normal process of development, just as in other areas of study. Side by side with this, however, have been the efforts of the national Slavic groups in the United States. These two streams developed for many years in almost complete separation, but between the two World Wars they began to affect each other. Since World War II, the two streams are slowly but surely merging and it is probable that in the future they will be completely consolidated to the advantage of Slavic scholarship, the American people, and the entire free world which still maintains those universal ideals that have come to dominate civilization. 


\section{SLAVIC STUDIES IN \\ THE NINETEENTH CENTURY}

Slavic studies Were slow in making a formal appearance in American colleges and universities. There were many reasons for this, not the least being the general submergence of the Slavic countries (except Russia) in the eighteenth century. At this period, the Slavic languages were little studied in Germany or France, far less in England and thus their absence in the United States is readily understandable.

In addition, the early American colleges, especially before the Civil War, had limited curricula. They were modelled on Oxford and Cambridge but, restricted in finances, libraries, and personnel, their curricula were largely adapted to the presumed needs of the day. They were intended to prepare men for the Protestant ministry or the law. Enrollments were small and confined to certain groups of the population. There was relatively little broad intellectual interest in the country although men like Benjamin Franklin, Thomas Jefferson or even Count Benjamin T. Rumford had won recognized places in the world of scholarship and of ideas.

The modern languages, chiefly French, were taught more or less by the same methods as the accepted classical languages and Hebrew. It was only in the first quarter of the nineteenth century that George Ticknor introduced at Harvard detailed work on modern European literatures. This was followed in the twenties and the thirties by the introduction of some Spanish and Italian, largely influenced by the revolt of the Spanish colonies in South and Central America.

We should not then be surprised that the earliest interest in the Slavic languages was shown by individuals who, by some means or another, had had contact with the Slavic world and whose concern was more or less amateurish. Some of these men were college graduates. Others had had no formal connection with the colleges of the day but had learned to know and appreciate Slavic culture and had set themselves the task 
of making and publishing translations in America. These began to appear shortly after the War of 1812. The Napoleonic Wars and later the war with England had interfered with American trade and commerce but had also stimulated American interest in Europe. This interest was also aroused by the Greek war for independence and the formation of a group of Hellenophiles in New England. Even before this, in 1810, the Congregationalists of Boston had established the American Board of Commissioners for Foreign Missions. It sent missionaries to the Near East and these, originally working to convert the Mohammedans, soon transferred their activity to Orthodox Christians and to the foundation of such American missionary educational institutions as Roberts College and the American University in Beirut, later to play so prominent a part in the Balkans and the Ottoman Empire.

The visit of the Marquis de Lafayette in 1825 also recalled the American Revolution and the services of the various foreign officers who had served in the American Army, including Generals Pulaski and Kosciuszko. Interest in Poland was again stirred by the Polish Uprising of $1831 .{ }^{17}$

Thus the growing American prosperity and the strengthening of the American national consciousness started a ferment which for a number of years caused a growing interest in some forms of Slavic culture in the United States, especially in New England. We must remember that this was before any mass Slavic immigration to the United States, although there were a considerable number of Slavs in the country, especially in the north and in the ocean shipping sections.

The first translator of Russian poetry in the Anglo-Saxon world was, in all probability, William David Lewis. ${ }^{18}$ His career is typical of this period. Lewis was born in 1792 in Christiana, New Castle County, Delaware. He received some education in Clarmont Seminary and Lower Dublin Academy and was then apprenticed to a merchant. However, his brother, John D. Lewis, who was established in St. Petersburg as a merchant asked his younger brother to join him in 1813. This was during the War of 1812 and the young man, in order to get to Europe, secured

${ }^{17}$ Cf,, A. P. Coleman, "A New England City and the November Uprisings," Annals of the Polish Roman Catholic Union Archives and Museum, (Chicago, 1939), IV, p. $31 \mathrm{ff}$.

18 Dictionary of American Biography, XI, p. 226; L. Wiener, Anthology of Russian Literature (New York: G. P. Putnam's 1902-3), I, viii; II, v. 
a post as private secretary to the peace commissioners. He sailed for Europe in 1814. Leaving his post at Gothenburg, he went on to St. Petersburg where he spent most of his time until 1824.

Lewis had excellent connections in St. Petersburg. He met and became friendly with Count Nesselrode, with the Cossack leader, Platov, and also with Nikita Ivanovich Grech, the editor of the Syn Otechestoa. He also seems to have met the elderly dean of Russian poetry, Gavril Romanovich Derzhavin. It was perhaps under the influence of Derzhavin and Grech that he began to translate Russian poetry. On January 31, 1821, apparently while on a visit home, he published in the National Gazette and Literary Register of Philadelphia a poem, Stanzas, by Yuri Aleksandrovich Neledinsky-Meletsky.

Lewis was becoming especially interested in the pre-Pushkin period of Russian poetry. However, in 1849 he also published in Philadelphia, where he made his home, a volume of translations entitled the Bakchesarian Fountain and Other Poems, a name taken from one of Pushkin's early poems. Grech saw to it that Lewis" book was appropriately reviewed and praised in the conservative Russian literary journals. However, Lewis was not primarily a man of letters and his contribution ends here. Even before he left St. Petersburg he had embarked upon a series of disputes with some of the American diplomatic representatives in the Russian capital and the next decades he spent as a successful business man and politician. For a time, 1849 to 1853, he was Collector of Customs in Philadelphia. He died in 1881. Lewis was slightly ahead of the work of Sir John Bowring who published in 1821-23, two volumes of Specimens of the Russian Poets. He followed these later with translations from Polish and Serb poetry, inspired by interest in the Serb folksongs. The translations were widely read in the United States.

The translations of Bowring, and a special interest in the works of Mickiewicz, determined the career of James Gates Percival. ${ }^{19}$ He was born near Hartford, Connecticut, in 1795 and was graduated from Yale in 1815. A student of languages, a poet of stature, an excellent geologist, Percival was eccentric and somewhat of a recluse. His works attracted little more than local interest and were soon forgotten. He finally became the state geologist of Connecticut and later of $W$ isconsin, where he died

${ }^{19}$ Dictionary of American Biography, XIV, p. 460; A. P. Coleman, "James Gates Percival and Slavonic Culture," Slavia, (San Francisco), XVI, No.

3, pp. 65-75. 
in 1856. For more than twenty years, though, he had done Polish translations and contributed articles on Polish literature and history to various periodicals. Some of these were little more than a re-writing of articles published in European journals, for Percival knew ten languages and was abreast of European developments. His knowledge of Polish was not too thorough, but at the period he influenced a group known as the "Connecticut Wits" and is a good example of the American interests of the time.

A more substantial contributor was the better known Talvj, ${ }^{20}$ the author of the Historical View of the Languages and Literatures of the Slavonic Nations. This was the first survey of the Slavic literatures after the works of Safarik. Talvj had a remarkable career. Her real name was Therese Albertine Louise von Jakob. She was born in Halle, Germany in 1797, where her father, Ludwig Heinrich von Jakob, was a professor at the University of Halle. In 1807 he was invited to give a series of lectures at the University of Kharkov. Therese soon became a competent linguist, began to translate the novels of Sir Walter Scott into German, and in 1825 published in German a collection of the Volkslieder der Serben, again in response to an interest in the Serb folksongs.

In 1828 she married Edward Robinson, an American Congregational minister and scholar who was then a professor in the Union Theological Seminary in New York. Robinson was much interested in Biblical archaeology, edited a popular religious journal, the Biblical Repository, and spent considerable time in the Biblical lands. He published his wife's work on Slavic literature in this journal. In 1850 it was issued in book form. When Robinson died in 1863, Talvj (her pen name was taken from the first letters of her name) returned to Germany. She died in 1870 in Hamburg. Talvj's book was probably the outstanding work on the Slavs done by a non-Slav in the first half of the century. Unfortunately it attracted little attention even though it was much sounder than were many of the studies written as much as a half century later. It received due recognition only after Slavic studies in the Anglo-Saxon world had begun to find themselves and had shown a certain independence of thought. 
The approach of the American Civil War and American preoccupation with western expansion turned interest away from Slavic themes. It was only near the end of the Civil War that we begin to find truly interested spokesmen for Slavic culture and even then the leaders were men who had personal connections with the Slavic World, often through service in the American diplomatic corps.

One of these was Jeremiah Curtin. ${ }^{21}$ Born near Milwaukee, Wisconsin in 1840 , after a common school education and some study at Carroll College, Waukesha, Wisconsin, he went to Harvard where he received his degree in 1863. A few months later, he met Admiral Lisovsky and the other Russian naval officers in the fleet that visited New York. They induced him to go to Russia and for a while, he was secretary of the American Legation there. On his return to the United States, he did some work on the folklore of the American Indian but later returned to Russia and traveled extensively in the Caucasus. He wrote a great deal about his experiences but achieved most of his fame by his translations of the novels of the Polish writer, Henryk Sienkiewicz. Sienkiewicz's Quo Vadis, in Curtin's translation, has kept its place as the most popular piece of Slavic literature in English. It has been produced several times in the movies and while Curtin's name is largely forgotten, his translations are still read and Sienkiewicz is still the best known figure in Polish literature among Americans.

Another American born in the same year, 1840, was Eugene Schuyler. ${ }^{22}$ A member of the celebrated Schuyler family, he was born in Ithaca and educated at Yale, where he graduated in 1859. He then went to the Columbia Law School and on leaving it in 1863, entered the American diplomatic service. He was American Consul in Moscow and Revel (Tallinn) and Secretary of the American Legations in St. Petersburg and Constantinople. While he held the latter post he made a full report on the Turkish atrocities against the Bulgarians in 1876. For a while he acted as Minister Resident in Greece, Romania and Serbia. He was regarded as somewhat too pro-Russian, though, and in 1889 the Senate refused to confirm him as Assistant Secretary of State. Schuyler died in 1890. His chief work was a two volume biography of Peter the Great which appeared in 1884 
and was the chief American historical work dealing with a Russian subject. While it has been outmoded by later historical research, the biography still stands as a monument to his scholarship and understanding of the Russian scene.

George Kennan was slightly younger. ${ }^{23}$ He was born in 1845 in Norwalk, Ohio. He received little formal education but became an expert telegrapher and was used on important assignments by the Western Union Telegraph Company, including service in the telegraph office of the White House during the Civil War. As the Civil War drew to its close, the American and Russian governments became interested in a plan for linking San Francisco and St. Petersburg by telegraph. Parties of trained men were sent to various points in the northwest and to Siberia to make the preliminary surveys and to build the line. Kennan was placed in charge of the section that was working in the northern part of Siberia. He spent some years in the wilderness there and became familiar with the life of the native population as well as the Russians. When construction was stopped after the completion of the Atlantic cable, Kennan traveled extensively in the Caucasus and spent some time in St. Petersburg. He recounted his experiences in a volume, Tent Life in Siberia, published in 1870. His familiarity with the natives of Siberia and the wilder tribes of the Caucasus led him to feel that Russia, with its multi-national population, was in a way similar to the United States of his day with its still unintegrated masses of immigrants and its still hostile Indian population.

After working as a reporter and war correspondent, he was sent in 1885, by the Century Company to visit and report on the Siberian prison camps. He was able to do this because of the many friends in high position that he had made during his previous visit. He was profoundly shocked by the conditions and his attitude, previously friendly to the imperial regime, turned into utter disgust. He secured priceless material from the Russian revolutionists whom he met on his travels and when he published it in the Century Magazine and later in book form, in 1891 (Siberia and the Exile System), it speedily became one of the outstanding denunciations of the imperial regime. It had much to do with opening the eyes of the Western World to the cruelty and barbarity of the imperial administration of justice. George Kennan continued his work as a reporter and war cor- 
respondent in both the Spanish-American and Russo-Japanese Wars. He died in 1924.

The last of this group of nineteenth century amateurs was Isabel Florence Hapgood. ${ }^{24}$ She was born in Wellesley, Massachusetts in $\mathbf{1 8 5 0}$ and passed most of her early life in Worcester. She early became interested in translating and after working in the chief European languages, began to teach herself Russian. She started work on translating Tolstoy and also published a book on the byliny, Epic Songs of Russia. In 1887 she made her first visit to Russia and met many important officials and writers. For the next twenty years, she dominated the Russian translation field in the United States with many translations from Tolstoy, Turgenev and other authors. In 1906 she brought out her greatest piece of work, a translation and adaptation of the Service Books of the Russian Orthodox Church, for which she received a gold watch from Tsar Nicholas II. The work was reprinted several times then, and again after World War I by the Young Men's Christian Association in Paris. For years she was a well known figure at the services of the Russian Orthodox cathedral in New York. She rarely missed a service and she carefully explained the ritual and its significance to the Americans who attended. Miss Hapgood paid another visit to Russia during the winter of 19161917 and on that occasion she was received by the Tsarina. She was in St. Petersburg when the Russian Revolution broke out. Her friends succeeded in getting her out of the capital and in enabling her to return to the United States through Vladivostok. Before her death in 1928, she saw her work replaced in large part by newer translations and she keenly felt the destruction of the old regime with which she had been connected for almost half a century. Yet her importance as one of the first serious translators from Russian into English must not be forgotten. She still remains an interesting figure in American-Russian relations.

This brief review of the leading figures makes it clear that they worked outside the educational system of the United States. They were persons who had developed, for one reason or another, a personal interest in Slavic affairs. Many of them had lived in one capacity or another, largely as members of the American diplomatic service, in some Slavic country. They were strict individualists and did not try to develop students or assistants. They worked as they pleased and on what they pleased 
and if their work was later recognized, they often paid no attention to it except for the pride any person feels in recognition and honor.

During this entire period, the colleges and universities had taken no part in the development. The educational system ignored both the Slavic culture and the steadily increasing number of Slavic immigrants. They continued the usual curricula and developed their courses and work in the traditional languages of Western Europe.

Yet the results which these individuals had achieved cannot be overestimated. By the end of the century the leading works of Russian literature, especially the novel, were generally known to American readers, though all too often from English versions of French and German translations. The appreciation of Polish culture had decreased during the century as the memory of Pulaski and Kosciuszko faded, not without the active cooperation of the representatives of Germany, Austria-Hungary and Russia which had succeeded in removing Poland from the European map and in presenting Polish artists and writers as members of their own states. The culture of the other Slavic peoples was even less known and studied.

Yet when we say this, we must never forget that the situation was little better in England. Even in France and Germany, Slavic studies had not really found themselves. It is true that professors like Jagic, August Leskien, E. Berneker and A. Brueckner had already started on their brilliant careers. Morfill and later Nevill Forbes in England were trying to hold up a standard. Even there, though, a study of the Slavic languages and culture, as well as the presentation of the great Russian novelists, was done in an highly out of context manner. So it also was in the United States where interest had been concentrated in the hands of a few select individuals who had worked on their own and for their own pleasure. 


\section{THE BEGINNING OF FORMAL STUDY}

THE SECOND HALF and particularly the last quarter of the nineteenth century was a period of rapid development in the American educational system. Even before the Civil War, ambitious young men, dissatisfied with the rigid curricula of the American colleges, had begun to go to Europe, chiefly to Germany, to study and secure the degree of Doctor of Philosophy. To a large extent the German universities came to take the place of even Oxford and Cambridge, the chief goals of the few preCivil War students who had gone to Europe.

In the same way, foreign scholars began to come to America. Again these were largely German or at least German-trained. Some of these men received, through some chance contact, direct invitations. Others, forced by the shifts of German politics and the Revolution of 1848, left their homes and joined the mass emigration to America that was already beginning. In either case, their influence was to the good.

In 1867, Johns Hopkins University was established as a definite post-graduate school, granting the doctorate. It was the first such establishment in the United States and President Gilman secured a distinguished faculty including such foreign scholars as Paul Haupt in Semitic Languages and Maurice Bloomfield in Indo-Iranian. Other outstanding men were soon appointed and the ideals of German scholarship were solidly established. Undergraduate work at Hopkins was regarded as merely an incidental in the first years of the institution's life.

The example of Johns Hopkins was not directly followed but it exerted a marked influence upon some of the more important of the older institutions. Harvard, Columbia, Yale, Princeton and a few others began to offer more advanced instruction and step by step the modern American graduate school, with its special course of study, was evolved. This process required some decades and each institution approached the problem in its own way, integrating the new work in accordance with its own traditions. As these developing universities broad- 
ened their interests and the range of their activities, it was only natural that sooner or later they would come to take into consideration the study of the Slavic peoples and their culture, especially of Russia. ${ }^{25}$

The first step was taken at Harvard under the influence of Archibald Cary Coolidge. ${ }^{26}$ In a very real sense, Coolidge was typical of the men whom we have considered in the preceding chapter. He was born in Massachusetts in 1866 and graduated from Harvard in 1887. He then went to the University of Freiburg for his doctorate, receiving it in 1892. During these five years, however, he took time out from his actual attendance at courses to serve as Acting Secretary of the United States Legation in St. Petersburg in 1890-1891 and to act, in 1892, as private secretary to his uncle, then United States Minister to France.

He returned to the United States in 1893 and took a position in the Department of History at Harvard. The next year he introduced a course on the history of northeastern Europe. This was, in other words, a course in Russian and Polish history. It was the first time anyone had offered a course covering Russia which did not view her history solely in terms of contacts with the West, the Eastern Question, the fate of the Ottoman Empire and the relations of Russia with the countries of Western Europe.

Professor Coolidge was an enthusiast and was deeply convinced of an American need to study the Slavic World. He expounded these views in a paper delivered before the American Historical Association in 1895. By the next year he had added a course at Harvard on the Eastem Question. At about the same time he secured the appointment of Leo Wiener as Professor of Russian Literature. This marked the actual beginning of Slavic studies in an American university.

Professor Coolidge never gave up his interest in the work. In addition to the courses that he gave, he superintended the building of the Slavic collection in the Harvard Library and served constantly as an adviser to the United States government on Slavic matters. He brought out, in 1915 , a volume on the Origin of the Triple Alliance and during World War I was one of the committee of scholars formed under the leadership

${ }^{25}$ For the general history of Slavic studies during the period, see: Kerner, "Slavonic Studies in America," Slavonic Review, III, pp. 244-258; Manning, "Slavonic Studies in the United States," Modern Language Journal, XIII (1929), pp. 280-288; XIX (1935), pp. 425-432; "Polish and the American Universities," Poland America, (N.Y,) XIII, pp. 489-491. ${ }^{25}$ For Coolidge, sce Dictionary of American Biography IV, p. 393. 
of Colonel House to prepare materials for the American Delegation at the Peace Conference. In 1918 he served as a special representative of the American government in Sweden and north Russia, and in 1921 he was sent by the American Red Cross to negotiate with the Bolshevik government on famine relief. In 1922 he founded Foreign Affairs, the organ of the American Council on Foreign Relations and the leading journal in this field. He personally acted as editor until 1927 when he relinquished the task to Hamilton Fish Armstrong who had been in the American service in Serbia during World War I. When Professor Coolidge died in 1928, he was the undisputed dean of American Slavic historians and the inspiration for a large part of the work that was then being done in the United States. His influence on the development of studies in history was greater than that of Leo Wiener on languages and literature.

Leo Wiener (1862-1939) published in 1902 and 1903 an Anthology of Russian Literature. This incorporated almost all the translations previously made, including excerpts from the greater Russian writers. The first volume, which included Russian literature up to Karamzin, still remains the best collection in English of the older literature. Where translations were unavailable, Professor Wiener made his own in prose. He also published in 1904 and 1905 a translation of the chief works of Tolstoy. Unfortunately in his later years, he lost interest in Russian and devoted his energies to studies of Ulfilas and the Gothic texts and many other questions far removed from his original field.

A great many of the scholars who becaine prominent in Slavic history before and during World War I were students of Professor Coolidge, who thus became the dominant force in the development of historical studies for many years. Among these was Frank A. Golder (1877-1929) who developed Russian history at Stanford University. He stressed, as we might expect, the American contact with Russia in the north Pacific and the Russian explorations in that area. In 1914 he published Russian Expansion in the Pacific (1641-1850) and later edited the accounts of Bering's voyages.

Another of Coolidge's students was Robert J. Kerner (18871956), born in Chicago. Kerner took his A.B. at the University of Chicago and then after study in Europe received his Ph.D. from Harvard in 1913. He was at first connected with the University of Missouri, but in 1928 went to the University of California at Berkeley, where he spent the rest of his life. He 
was made Sather Professor of European History in 1941. When he retired, in 1954, he was also Director of the Slavic Institute of the University of California. Professor Kerner, who was of Czech origin, did most of his work in Czech history, especially the period following the Battle of the White Mountain. In 1932, he published Bohemia in the Eighteenth Century: a Study in Political, Social and Economic History, with Special Reference to the Reign of Leopold II (1790-1792). He published other works on the Western Slavs and the Balkans. He was recognized by the scientific societies of both Czechoslovakia and Romania before World War II and was decorated Commander of the White Lion of Czechoslovakia, and Officer of the Crown of Romania. Belgium also honored him for his work at the Peace Conference of 1919 as well as for later services.

Another pupil of Professor Coolidge, Robert Howard Lord (1885-1954) took his degree in Harvard in 1910 and remained there on the faculty. In 1915, he published The Second Division of Poland. During and shortly after World War I he was very active in Polish studies and served on the House Commission of Scholars to prepare materials for the Peace Conference in 1919. However, he suddenly gave up this field of scholarship, resigned, his post, completely withdrew from previous scholarly contacts and began to study for the Roman Catholic priesthood.

Perhaps the most important of all of the Harvard students of this period was George Rapall Noyes (1873-1952). A native of Massachusetts, he studied with Professor Wiener. From 1898 to 1900 , he held a Harvard University Fellowship for study at St. Petersburg. Upon his return, he spent a year as Assistant Professor of English at the University of Wisconsin and then went to the University of California as Assistant Professor of English and Russian. In the first year of his work at California he had only five students in Russian and one in Czech, but as the numbers grew he gradually dropped his work in English and by World War I he was able to devote himself entirely to Slavic studies.

During the War, he secured Alexander Kaun as his assistant. Kaun was born in Russia in 1889 and studied from 1905 to 1907 in the Free University of St. Petersburg. He then came to the United States and from 1909 to 1916 taught Hebrew in Chicago. He went to California and in 1917 became Assistant in Russian. He took his M.A. and Ph.D. there and remained on the faculty, rising to the rank of Professor in 1943. Kaun was decidedly leftist 
in his sympathies and was a typical member of the Russian intelligentsia in its narrowest sense. He was one of that group far more interested in theoretical than practical reforms. This brought him very close to those members of the intelligentsia who were most inclined to sympathize with Communism; it determined his views on Maxim Gorky and Andreyev, the subject of two of his works. He also contributed many articles on Soviet literature. Professor Kaun died in 1944.

In 1920, George Z. Patrick was added to the University of California staff. Born in Nizhny in 1883, Patrick traced his name and ancestry to an Irishman who went to Russia after the Battle of the Boyne in 1690. Educated in the Faculté de Droit in Paris and the Moscow Law School, from which he was graduated in 1912, he came to America with one of the Russian commissions sent by the Provisional government. After its fall, he went to California and in 1920 was appointed Lecturer in French and Russian. In 1923 he dropped his French work and devoted himself entirely to Russian. In 1940 he was appointed to a full professorship. However, his health was poor and after years of suffering and long periods of inability to work, he died of tuberculosis in 1944. Patrick was undoubtedly the best teacher of Russian that the American universities have had. He was a charming and sincere man and was the best beloved professor in the field.

The addition of Kaun and Patrick to the staff at the University of California allowed Noyes to give up most of his Russian work and devote himself primarily to Polish. He visited Poland in 1921 and was welcomed at the University of Krakow where he stayed for some months. The Polish government decorated him as Commander of Polonia Restituta and several Polish scholarly societies elected him to membership.

Even in his early days at California, Noyes commenced his work of translation. Among the earliest was a collaboration, the Heroic Poems of Servia, with Leonard Bacon of the English department. Later Noyes, with the aid of numerous assistants, translated most of the important works of Mickiewicz, Slowacki and Krasinski, and also many Russian dramas including a volume, Masterpieces of Russian Drama, ranging from Fonvizin to Mayakovsky. It was his practice to write out a very careful prose translation and then have some of his students and associates set them, when necessary, into verse. Noyes really founded a special school of translation. 
He was an earnest and sincere student, mild but demanding, especially of himself. $\mathrm{He}$ carefully laid out his projected work for years in advance and maintained a rigid schedule. Any pressure of university duties or unforeseen calls upon his time he met by including in his work schedule all those periods which he had left himself for vacations. When he died in 1952, he was the last of the old generation. He left a gap in Slavic scholarship that has not yet been filled.

The interest in Russian on the Pacific coast was reflected not only in the appointment of Golder to Stanford's history department. In 1918, Henry Lanz was appointed Professor of Russian Literature and Philosophy there. Lanz had been born in Moscow in 1886. He was not a very prolific writer but one of his works on rhythm of language received a prize from Sweden. Just before the outbreak of World War II, he made another trip to Europe and stayed for some time in one of the monasteries on Mount Athos. He died in 1945.

Another outstanding figure of the period was Samuel $\mathrm{N}$. Harper (1882-1943) of the University of Chicago. Harper was the son of the first president of the University of Chicago. He studied in the Ecole des Langues Orientales in Paris and was closely associated with the group of English Slavists who, under the leadership of Sir Bernard Pares, K.B.E., gathered at the University of Liverpool and after the war formed the School of Slavonic Studies at the University of London. Harper was in Russia with Pares during the Revolution of 1905 and was very friendly with such liberal Russian leaders as Paul Milyukov. In 1906 he published an English translation of Boyer and Speranski's Russian Reader and in 1908 a volume on the New Electoral Law for the Duma. Through his connections at the university and Charles R. Crane, both Milyukov and Maxim Kovalevsky were brought to Chicago for lectures. Harper was a constant adviser to the United States government on Russian affairs. He was convinced that the Russian people, if they had the power. would definitely accept the Anglo-Saxon theories of democracy, a position which he maintained in his dealing with the Russian emigres after the Revolution. He was solidly anti-Bolshevik but in the thirties he accepted an invitation to visit Moscow, about the same time as Pares did.

Harper had a wide knowledge of Russian history, and when he was not traveling. lectured in Chicago and conducted courses in Russian. Yet he did not build a department of Russian and, 
despite the large Slavic population of the city, showed little interest in introducing other Slavic languages or cultures.

Another important center, started just as World War I was beginning, was at Columbia University. Although Dr. Judah A. Joffe had been appointed a lecturer in Russian for one year, in 1909, to prepare some articles and lectures on Russian literature for a volume on European literatures which the university was publishing, the serious work was begun only when John Dyneley Prince, then Professor of Semitic Languages and an authority on Assyrian and Sumarian, offered courses in Russian and Slavonic philology. Prince was born in Paterson, New Jersey, in 1868 and was an 1888 graduate of Columbia. He took his doctorate at Johns Hopkins in Semitic and conducted excavations in Mesopotamia. He was later Dean of the graduate school of New York University and then was brought to Columbia.

In addition to his academic work, Prince was greatly interested in conservative New Jersey Republican politics. He served as both Speaker of the House and President of the New Jersey Senate when Woodrow Wilson was Governor. In 1921, President Harding appointed him United States Minister to Denmark and President Coolidge in 1926 transferred him to Yugoslavia. He was absent from the university therefore from 1921 to 1933, when as an ardent Republican he retired from the diplomatic service after the election of President Franklin Delano Roosevelt.

Prince was an unusually talented linguist who fluently spoke nearly all European languages, including Hungarian and Turkish. He was also a master of several Algonquin Indian dialects and a masterly singer of folksongs. He had previously turned this unusual ability to good use in his political campaigns among the New Jersey voters of various foreign nationalities. When he turned to Slavic, he easily mastered nearly all the languages and soon was able to speak them readily. In addition, he was an excellent philologist and it was in this field that he most enjoyed himself. He published a Russian Grammar in 1919 under great difficulties because of the general lack of proper type. Later he published grammars of both Latvian and Serbo-Croatian. He was also a great friend of Professor Michael I. Pupin, the distinguished Serb professor of electricity.

All these abilities made him determined not to allow the 
department, at Columbia, to be limited only to Russian. He offered courses in 1914 on a graduate level with Ivan S. Andreyevsky as assistant. At the same time, through University Extension, he started credit courses in Polish with Dr. Albert Morawski-Nawench as instructor. Dr. Morawski-Nawench was a Polish journalist and editor who had received his doctorate at the University of Vienna. Czech was offered by Alois Koukol, a Presbyterian minister, born in Kutna Hora and educated in Prague.

In addition to these courses, Prince opened in Columbia University Extension a special school of spoken languages. These were non-credit courses and Prince hoped to develop them, in time, into something like the Ecole des Langues Orientales. Courses were offered in some twenty languages. This undertaking was nipped in its infancy by Prince's appointment to Denmark, for after his departure the original program was abandoned. It had considerable effect for some years, however, both upon the Department of Slavonic Languages and several others.

In 1917, Prince invited Clarence A. Manning to be Lecturer in Slavonic languages. Manning had received his doctorate in Greek and Latin at Columbia in 1915 and had become interested in Russian while on a Cutting Fellowship, traveling in Europe at the outbreak of World War I. He was on leave of absence from the university in 1918-1919 while serving in the Corps of Intelligence Police and the Translation section (M.I. 6) of the United States Army War College. During Prince's absence, he served as acting executive officer of the department.

On his return to Columbia, in 1933 Prince resumed his professorship but because of failing health and eyesight he retired in 1937 . He died in 1945 . In this early period, two doctorates were conferred. One was conferred on Mr. Avrahm Yarmolinsky, Director of the Slavic department of the New York Public Library, for a study of Dostoyevsky's ideology; the other on Milivoy S. Stanoyevich, for a work on early Yugoslav literature.

In addition to these main centers, there were several other developments worthy of mention. Professor William Lyon Phelps, the distinguished professor of English at Yale University, published in 1911 a popular work, Essays on the Russian Novelists. $\mathrm{He}$ was assisted in preparing this by Max S. Mandell who for 
a decade continued to give courses in the Russian language. Mandell also published a translation of the plays of Turgenev and several other works.

Professor Clarence L. Meader of the Department of Classics at the University of Michigan also mtroduced courses in Russian and published a translation of the plays of Andreyev. Professor Harold H. Bender of Princeton, starting from a study of linguistics, came to stress the influence of the Baltic and Slavic languages, especially Lithuanian. In neither case was there a department definitely established at this time.

There were also a great many professors in various other fields who did valuable work on Slavic subjects. It would be impossible to list all of these works though some should be mentioned.

Professor Vladimir Simkhovich was appointed a professor of Economic History at Columbia in 1904. There he continued work which he had started at the University of Jena in 1899 on Die Feldgemeinschaft in Russland and, in 1908, Die Bauernbefreiung in Russland. Several dissertations on Slavic subjects were accepted by the faculty of political science at Columbia, such as the Eastern Question by Professor Stephan Duggan in 1902 and the Making of the Balkan States by W. S. Murray in 1910.

Professor Ales Hrdlicka, the distinguished Czech anthropologist and authority on the population of the Aleutian Islands, published several works on the Czechs and on the Races of Russia for the Smithsonian Miscellaneous Collection for 1919.

Professor E. A. Ross, a sociologist of the University of Wisconsin, was in Russia during the Revolution and published Russia in Upheaval in 1918, Russian Bolshevik Revolution in 1921, and Russian Soviet Republics in 1924.

Paul R. Radosavljevich, Professor of Experimental Psychology at New York University, published in 1919 the two volume work, Who are the Slavs? This was a serious attempt to study Slavic psychology and to identify, if possible, features common to all Slavic nations.

A psychology professor, Will S. Monroe of the New Jersey State Normal School in Montclair, traveled extensively in both Czechoslovakia and Bulgaria and published Bohemians and Czechs in 1910 and Bulgaria and its People in 1914.

Other men who were active, some of them students of Profersor Coolidge, were: Professor Arthur I. Andrews, Tufts Col- 
lege; Professor A. J. Shipman, Princeton; Professor Sidney Bradshaw Fay, Smith College, and Professor Bernadotte Schmitt, University of Chicago. Most of these knew Russian or one of the Slavic languages but at this period there was no generally accepted rule that the students of Slavic themes had to be familiar with the original sources and many of the dissertations and books published were by men who used materials available in French, German, or rarely, Latin,

There were also many scholarly books by persons who had little or no university connections. Included in these are the translations of Russian Poetry by Babette Deutsch, the wife of Dr. Yarmolinsky, and the volumes by Julius F. Hecker.

America's entrance into World War I revealed the American people's need for more accurate knowledge of Slavic affairs. This was especially shown by the confusion which prevailed, even in official circles, concerning the Russian Revolution and the rise of Bolshevism. ${ }^{27}$ It became still more apparent when the committee, brought together through the efforts of Col. Edward M. House, to consider the effect of the peace found themselves hampered by lack of material on the non-Russian peoples of the Russian Empire. The German materials on these people were suspect, and the Russian a sealed book to all except a very few of the committee members, and there was almost no one to deal with materials in the native languages, especially when the material was not Slavic.

Before the War, German had been the chief foreign language taught in the American schools and universities. However, hostilities brought general anger against the Germans and also against certain German professors who placed themselves all too readily at the service of the German government. This resulted in widespread opposition to the use of German and, in fact, to any foreign language. Some states, such as Nebraska, where there was a large population of German origin, went so far as to forbid the teaching of any foreign language within the limits of the state, a ban which was later overruled by the United States Supreme Court. Even where this extreme was not reached, the number of students of German declined almost to nothing and many members of the university faculties either were dropped from their posts or were faced with that possibility.

${ }^{27}$ For a recent description of this, see George Kennan, Russia Leaves the War, (Princeton, N. J.: Princeton University Press, 1956). 
In this crisis, and in the hope that the Russian Revolution would promote democratic contacts and trade with the United States, some of these former German professors announced courses in Russian. There was often something humorous and grotesque about this, for there were few if any textbooks and the professors themselves had little knowledge of the language. The situation in some cases was scandalous. There is little reason to do more than mention the existence of this situation. Even well-known scholars lent themselves to it, only to report a few years later that there was no call for Russian. As a result, the sudden flurry of Russian courses was without result and in the years after the War, they were more or less quietly abandoned. It accentuated the common notion that Russian could not be learned, an idea energetically fostered for various reasons. No one took the trouble to realize that the necessary preliminaries, such as the publication of grammars, were yet to be done. There were no books available, save a few published in England, and no real teachers, save some chance immigrants who owed their opportunities more to good fortune than to ability or training. Yet the war period did serve to strengthen those departments which had been previously established. It brought a few new individuals into the picture and above all it aroused a sense of need that was slowly to be satisfied. 
CHAPTER 5

\section{SLAVIC EFFORTS BEFORE WORLD WAR I}

IN THE PRECEDING CHAPTER, dealing with the gradual development of an intellectual interest in Slavic questions, we have largely ignored the activity of Slavic groups in the United States. This was deliberate, for the early stages of Slavic study were almost completely apart from the work of the Slavs themselves and involved only those persons who had come to the United States and achieved prominence or success outside of their own communities and background.

These early Slavic efforts could make little imprint upon the American public, for the first steps were taken under most adverse conditions. The Slavic masses were composed for the most part of the underprivileged groups who had come to America in the hope of working for a few years and then returning. Later they became American citizens, but until 1914 a surprising. percentage of the Slavs had not taken out citizenship papers.

For their self-protection and mutual advantage these masses had formed their own churches and fraternal organizations. There were in the nineteenth century many difficulties to be encountered by each and the communities lived apart with relatively little social or political contact with the rest of the population.

As entire families began to settle, their children were compelled to attend the American public schools where instruction was given only in English. It was not long before the preservation of their native languages became a burning question, to be acted on by the establishment of language schools held outside of regular school hours, in the late afternoons, evenings and on Saturdays. For example, the first Czech school was founded in 1862 by the Slovanska Lipa Society of Milwankee, Wisconsin. In 1864, the first Czech schools were established in Chicago and, in 1866, in New York. The exanple of the Czechs was followed later by the Poles, the Slovaks, the Croatians, the Serbs and the Ukrainians. 
These schools were conducted by the best educated men or women in the community, though this did not of necessity mean much. Classes were usually held in the building of a church or other organization, but sometimes in private homes or in public school buildings, the use of which was given free by the American school authorities. The textbooks were inadequate, often being those which the teacher had studied years before in the home country. Sometimes they were heavily laden with political propaganda, as were the books prepared for the Carpathian population by the Hungarian government which exercised a considerable influence through the Greek Catholic priests who were Magyaron in tendency as a result of their early upbringing. The situation was made worse by the fact that the schools in the homelands were themselves unsatisfactory, either in the hands of the alien rulers or the products of the vague stirrings of the population to secure their own more or less illegal schools..$^{28}$

Despite all this, these schools did achieve some success but not enough to be regarded as a satisfactory solution of the problem. Life in America, even with its lack of legal barriers or restraints, was unfavorable to active continuation of a foreign tongue. The contrast between these impromptu courses and the developing American school system was too striking to escape the attention of the pupils in the two types of schools as well as the more intelligent leaders of the community. In addition to this, these schools failed to give the students an adequate picture of the progress that their relatives at home were making.

The Roman Catholic schools were gradually remodelled on the normal parochial school system. The teachers were, for the most part, nuns and brothers from orders working among a particular national group. Their quality of teaching was often quite low but the Church schools did enjoy the possibility of incorporating the innovations which were coming into the parochial schools. Thus as the parochial schools were improved, so were the foreign schools under Church auspices.

In the Orthodox and Catholic Uniat Churches, such instruction was usually given by the dyak or cantor, a layman who superintended the choirs and took a part in the services. These men had some education but little training in teaching 
and their efforts were largely directed along the same lines as in their homelands.

The Protestant and anti-clerical groups endeavored to find competent laymen. These stressed the holding of classes in some lay building or on the property of some secular organization.

As early as 1881, a journal in Johnson County, Iowa, the Slovan Americky, started a campaign to raise money for a Czech college in America. The newspaper believed that it could accomplish its purpose if it succeeded in raising $\$ 20,000$. The proposal, being launched by a single newspaper, did not secure the support of rival papers and the entire enterprise was dropped as a failure. ${ }^{29}$

Out of this chaotic and thoroughly unsatisfactory situation two tendencies became evident just before World War I. Those Catholic schools which had acquired some stability and organization began to take the shape of the other parochial schools and where there was sufficient demand and a sufficient concentration of worshippers, they began to approximate the parochial high schools and then to pass over to be two or three year colleges. The work of these was still not of high calibre but the leaders. were constantly striving to make them so. Thus, the Czech Benedictines founded a school in Chicago in 1887. This passed through the usual changes and.after its removal to Lisle, Illinois, in 1901 it was reorganized as St. Procopius College, now a duly accredited Catholic institution. St. Vincent College, Latrobe, Pennsylvania, with a marked emphasis on Slovak, is another of these institutions.

We find the same activity among the Poles. St. Mary's Seminary, Orchard Lake, Michigan, early included Polish in its curriculum, as did St. Francis Seminary, Milwaukee. Various religious orders have long conducted courses in the Polish language on the high school level in various centers of population. The Polish Roman Catholic Union, with its library, was highly developed by Mieczyslaw Haiman, especially in publishing studies of the career of such Polish soldiers in the United States as Tadeusz Kosciuszko and the other Poles who fought in the American Revolution. The Polish Historical Society also has done outstanding work. All these represent the natural development of the Poles and their descendants in America, and deserve more than passing mention. 
At the turn of the century, the fraternal organizations also began to give the question of schools due consideration. Almost all appointed committees on education and they too decided that the primary need was the foundation of special colleges where instruction could be given in the language of the homeland. Thus, in 1902 there was formed in Cedar Rapids, Iowa, an institution, Matice Vyssoho Vzdelani, a center of higher studies, by Bohumil Simek and G. F. Severa to work for the establishment of a Czech college, but it also met with no success.

In 1903, the Polish National Alliance also created a committee on education and schools, which worked for ten years and then in 1912, at Cambridge Springs, Pennsylvania, opened the Polish National Alliance College which was incorporated in 1914. Although it was rather on the level of a high school, it profited by the opportunity to establish a branch of the Student Army Training Corps during World War I. Its first rector was Professor Romuald Piatkowski. In 1915, the work of the high school or academy was augmented by the foundation of a Technical Institute. It was in this status that the institution passed into the next general period. ${ }^{30}$

Other forces were at work, however, to preserve the native languages by introducing the Slavic languages into the already established American institutions. While the motives were varied the efforts were made first by the less clerical and the more Protestant parts of the population. Thus, in 1887, the Congregational Church in Ohio persuaded the authorities of Oberlin College at Oberlin, Ohio ${ }^{31}$ to introduce a course in Czech for candidates to the Congregational ministry who would minister to the Czech communities. Professor Louis F. Miskovsky was appointed instructor, and his became the first chair of Slavic studies in an American institution. Oberlin's program differed from the later attempts at Harvard and elsewhere in that it was frankly intended only to teach the language. Any Slavic cultural work in a broader sense was insignificant. It is small wonder then that on Professor Miskovsky's death in the 1920 's, the chair was quickly abandoned and the money used for a course of lectures on Central European affairs given by Professor Oskar

${ }^{30}$ Facts concerning the history of Alliance college have been supplied by President Coleman.

31 Concerning Oberlin, cf. "Teaching of Area and Language Course in the Field of Slavic and East European Studies," American Slavic and East European Review, IV (1945), pp. $85 \mathrm{ff}$. 
Jaszy, a liberal Hungarian who opposed both Communism and the regime of Admiral Horthy.

In somewhat the same way, and for the same purpose, instruction in the Polish language was introduced into Notre Dame University in 1909.

Efforts to include a Slavic language, usually Czech, in the curricula of state and private colleges were particularly intense in Nebraska and Iowa. ${ }^{32}$ In these states, the Czech population had been among the earliest settlers; many had prospered and secured appointive and elective posts in the state governments, which gave them the opportunity to work for the introduction of their native language into various institutions.

In 1903, Professor Bohumil Simek of the University of Iowa and F. J. Pipal, a student of the University of Nebraska, established at Lincoln the first of the Komensky Educational Clubs. These clubs were intended to unite the Czech-Americans who had some education. The movement, which included plans for building a monument to the Czech educator Jan Amos Komensky (Comenius), spread extensively and finally included twentynime societies, chiefly in the states of Nebraska and Iowa, although there were some in Texas, Chicago and New York. For a while this loosely knit organization was even able to publish a periodical bulletin. ${ }^{33}$

These clubs petitioned at once for the establishment of Czech language courses at the University of Nebraska. Although the request was turned down on the ground that there was a lack of interest in such a project among the Czechs, a new attempt was made during the winter of 1906-07. John Rosicky, an outstanding publisher of Czech newspapers in Nebraska, and Vaclav Bures, both of Omaha, met the Regents of the state university along with Frank Rejcha, a member of the Nebraska legislature. The Chancellor of the university, in refusing the request, proposed a political deal whereby a tax of one mill would be laid on certain railroad properties and earmarked for the university. By clever lobbying, the Czechs secured passage for the bill. Then the Governor of the state cut the grants to the university and the Chancellor again declined to set up a Slavonic department. Later the same summer, however, another request was more successful and courses were started in the fall of 1907 .

The first instructor was Jeffrey Dolezal Hrbek, a graduate 
of Lafayette College, Easton, Pennsylvania, and, at the time, a student in the University of Iowa. He was appointed head of the new Department of Slavonic and instructor in the Germanic languages and literatures. Unfortunately Hrbek, a young man of great promise, became ill and died on December 4, 1907.

He was succeeded by his sister Sarka B. Hrbkova, who graduated from the University of Iowa in 1909 and received an M.A. from Nebraska in 1914. Under her period of teaching, the department flourished. In 1910 she was named adjunct professor; in 1914, an assistant professor; and in 1918, she became a full professor. She was also very active during the war in various aspects of Czech-American relations.

During World War I, the outburst against the use of German spread in Nebraska to all foreign languages. The courses in the university were dropped and the department was abolished, while Professor Hrbkova moved to New York and became the manager of the Czechoslovak Section of the Foreign Language Information Service, ancestor of the Common Council for American Unity. The outburst was even worse against Czech courses in the lower schools and in 1919 the so-called Siman Bill provided that "no person, individually or as a teacher, shall, in any private, denominational, parochial or public school, teach any subject to any person in any language other than the English language." This was made more stringent in 1921 but in 1923, the measures were declared unconstitutional by the United States Supreme Court.

In the meantime, the break in the university courses was less prolonged. In 1919-20, during the meeting of the State Constitutional Convention, two members of Czech origin raised the question of a renewal of the courses. After negotiations, the teaching of Czech was renewed in the autumn of 1920 under Professor Orin Stepanek. Stepanek, a native of Nebraska, received his A.B. from the University of Nebraska in 1913 and an A.M. from Harvard in 1914. After service in the U.S. Marine Corps he returned to Harvard and then went to serve under General Snejdarek on the Magyar frontier. After this, he returned to Nebraska and there became Assistant Professor of English. While there, he was also giving courses in Czech and Russian under the auspices of the Department of Modern Language and, later, of Romance Languages.

We have stressed the history of the establishment of Slavic work at the University of Nebraska because the Czechs were 
sufficiently numerous and influential to be able to reach the university authorities and the state legislature. More than that, they were persistent and finally succeeded in securing recognition. Yet in its way, the same type of politics, in addition to formal applications, was going on with various degrees of success in many different places.

At about the same time, Czech was included in the University of Iowa where Miss Anna Heyberger conducted the work. Still later she changed to Coe College at Cedar Rapids where she became Professor of French and took a doctorate, with a dissertation on the Czech educator Jan Amos Comenius, at the University of Paris. Alois Barta was then giving instructions at Dubuque College and Seminary. For a while before World War I, B. Prokosch gave courses in Czech at the University of Wisconsin and Leon Zelenka Lerando at Ohio State University but more lasting results were obtained by Mr. Charles Knizek at the University of Texas, where Czech has continued almost without a break since its introduction. ${ }^{3 *}$ At this time, still other developments, largely connected with the various churches, were ensuing. For example, Reverend Andrew Slabey was appointed to the International Baptist Seminary in Montclair, New Jersey, an institution greatly concerned with training clergymen for missionary work among various non-English groups and extensively staffed for such foreign langliages as Slovak, Ukrainian and Hungarian. On the other hand, the Russian Orthodox Archbishop of the Aleutian Islands and North America established a small Russian seminary at Minneapolis, Minnesota. This was later moved to Tenafly, New Jersey, and its head was Reverend Leonid Turkevich, the present Archbishop Leonty of the Russian Orthodox Church in North America.

We could extend this list even further, but the institutions at this period cared for little more than the giving of elementary instruction in a Slavic language, usually either Czech or Polish. The period witnessed the publication of a considerable number of elementary grammars, dictionaries and readers. Many of these were not of high quality but they did reflect the growing maturity of the various Slavic communities and their efforts to secure the introduction of their languages into the curricula of American institutions. Furthermore, at this period, it was rare that any person in one of these smaller state institutions 34 Thomas Capek, History of Bohemians (Czechs) in America. 
could secure a post exclusively in Slavic studies. The best and most scholarly were compelled to carry almost a full load in some other subject. But the mere fact that this was possible accents the increasing number of young Slavs who were securing college and university educations. The situation was still not healthy but at the beginning of World War I it was by no means as hopeless as it had seemed earlier. 


\section{FROM 1914 TO 1939}

As We HAVE SEEN, Slavic studies were in their infancy when World War I broke out. The American reaction to the War was, as we might have expected, a plain paradox.

American public opinion concentrated on the Western Front and the campaign in France and only slowly did it begin to react to the enormous forces that were working in the central and eastern parts of Europe. As in most countries of Europe, the only persons who took a deep interest in these areas were the immigrants and the few persons who had already been awakened to the great problems which the Slavic world of the time presented.

The clash of Great Britain, France and Russia against Germany, Austria-Hungary and Italy, the Triple Entente versus the Triple Alliance, seemed real only in its relations to the Western Front. The Eastern Front and the titanic passions released in the Slavic lands under both Russia and Austria-Hungary seemed fantastic to public opinion and even to the opinion of the educated and intelligent classes. At the same time, it did have a message for the Slavic communities in the United States which sought every opportunity to raise their voice in hope of national liberation. The average American was more moved by the Armenian massacres than he was by the astounding Russian advances and retreats in the East. The causes which led the United States into the War were almost wholly connected with the respective influences of Great Britain, France and Germany and it was the armistice with Germany on November 11, 1918 that convinced the American people that the War was over and that the whole of Europe would very soon return to normalcy,

Consistent with American preoccupation with the developments in Germany, the agitation for the disintegration of Austria-Hungary vigorously sponsored by the Slavic colonies in the United States and the various national committees in Europe found a hearing chiefly as a means of curtailing German influence. Furthermore, as a result of propaganda diligently spread 
during the War, the Russian Revolution seemed to the majority of the American people another step in the development of democracy and the break up of the control of Russia by a Germanized royal family and a Germanized bureaucracy. It might even be said that the initial distrust of Lenin came because the German General Staff allowed him to cross to Russia from Switzerland. The disintegration of the Russian front was laid entirely to German propaganda and the most ridiculous stories were advanced in order to justify this point of view. This attitude prompted the American reaction to the efforts of liberation of the various peoples of the old Russian empire and nearly all the nationalist movements were laid to German influences.

We may see this in the phrasing of the sixth of Wilson's Fourteen Points touching Russia:

The evacuation of all Russian territory, and such a settlement of all questions affecting Russia as will secure the best and freest co-operation of the other nations of the world in obtaining for her an unhampered and unembarrassed opportunity for the independent determination of her own political development and national policy, and assure her of a sincere welcome into the society of free nations under institutions of her own choosing and more than a welcome, assistance of every kind that she may need and may herself desire.

On the other hand the non-Russian peoples of the old empire paid no attention to these remarks by President Wilson. They saw rather the general principles enunciated in the Fifth Point, "A free, open-minded and absolutely impartial adjustment of all colonial claims based upon a strict observance of the principle that in determining all such questions of sovereignty the interests of the populations concerned must have equal weight with the equitable claims of the Government whose title is to be determined." In fact he went further and on July 4, 1918 he declared in the "Four Ends" speech: "The settlement of every question, whether of territory or sovereignty, of economic arrangement, or of political relationship, upon the basis of the free acceptance of that settlement by the people immediately concerned, and not upon the basis of the material interest or advantage of any other nation or people which may desire a 
different settlement for the sake of its exterior influence or mastery."

Thus the doctrine of self-determination definitely pronounced by President Wilson was carried still further by the people of the old Russian empire than he had himself intended. He only provided for independence for Finland, Poland and Armenia, three peoples who had won the special sympathy of the American people. In the case of all others, he was prepared to rest upon his Sixth Point and neglect careful and accurate study of the conditions prevailing in Eastern Europe.

If space permitted, we could trace this idea in the American attitude to the Peace of Brest Litovsk, the actions of the American Expeditionary Forces in Archangel and Vladivostok, the attitude toward the Russian White armies, the refusal to grant an Eastern border to Poland under the Treaties of Versailles and Saint Germain, the refusal to recognize the cession of Bessarabia by Russia to Romania and many other questions. It insured high favor from those entirely removed from AustriaHungary and Germany and relative disfavor from all peoples trying to separate themselves from Russia.

It is true that from the very beginning of the conflict the leading intelligence officers like Colonels Ralph Van Deman and Marlborough Churchill, the real moving spirits of the military intelligence branch of the General Staff, recognized the importance of the Slavic languages, and Colonel Graham D. Fitch included the Slavic languages among those handled in the Translation Section of which he was the chief. Yet on the whole, the Corps of Interpreters and other concerned branches and units paid little attention to them and nearly all the American agents in the Slavic territories were persons who had already known the languages. Even in the case of the Siberian and Archangel expeditions, the problem of interpreters was not placed on a firm basis. For some years after the War, almost all the officers and men in the State Department were persons who had served in these forces and had attained a certain amount of Russian or some other language without any formal training.

The situation was the same in the committee formed by Colonel Edward House to study the peace settlement. It is true that most of the professors of Slavic were connected with this but it was very soon discovered that much of the available material could not be used unless it was in one of the Western 
languages or, in some cases, in Russian (and, of course, with a Russian bias).

Thus the World War, and American participation in it, did not result in any marked increase in interest and there was for some years a strong feeling that a knowledge of the languages was secondary. The old divisions between language and the historical sciences were still perpetuated, gradually breaking down between the wars.

It is true that after the War, the War Department made a half-hearted attempt to train certain regular officers in various subjects with a possible eye for making them instructors in West Point. These included two men who had been on the Siberian Expedition. Lt. Col. Benjamin B. McCroskey and Captain William Gent were sent to study in the Department of Slavonic Languages at Columbia University. With the growth of isolationism the experiment was not pressed, and step by step all of the government services lost interest except for a few young men in the State Department who were often sent in some indefinite capacity to the Baltic republics with the intent of learning Russian.

Thus, at the end of the War, there had come no important change in the general picture. The departments of language in Harvard, California and Columbia continued, perhaps with increased staffs, and Professor Harper in Chicago went on with his work also. On the other hand, there were a number of universities and colleges, chiefly in the Middle West, where one or more Slavic languages were taught, often under the pressure of local Slavic groups. These included Nebraska where Orin Stepanek was teaching. Czech was also added to the curriculum of Creighton University in Omaha and the University of Texas in Austin. There were energetic stirrings among the Poles to introduce their language at the University of Wisconsin. There were men in various other institutions such as Professor Leon Zelenka Lerando in Lafayette College who, in at least part of their work, handled one or another language. Yet in the course of the years many of those institutions which had included Russian during the War abandoned it. ${ }^{35}$

${ }^{35} \mathrm{C}, \mathrm{W}$. Hausek, The Slavonic Languages and Literatures in American Colleges and Universities (Washington, 1920); Manning, "Slavonic Studies in the United States," Modern Language Journal, XIX, (1935), pp. $425 \mathrm{ff}$, "Slavonic Group of the Modern Language Association of U.S.A. (Slavonic Group)," Slavonic Review, XI (1933), p. 521; "The University and East European Cultures," Columbia University Quarterly, 
A rather unique case occurred at Dartmouth College. Professor R. W. Jones, who was in the German department, knew some Russian. But, one of the professors of the English department was Eric P. Kelly, who had been in Poland with the YMCA during the War and had become vitally interested in the country and its culture. In 1928 he published a very successful boy's story on medieval Poland, The Trumpeter of Krakow, which won the Newberry Prize for Juvenile Books. Later he wrote two more on Polish themes, The Blacksmith of Wilno and The Golden Star of Halich. Through their influence, William J. Rose, a Canadian and later the Director of the School of Slavonic and East European Studies in the University of London, was brought to Dartmouth for a few years. At one time it looked as if Dartmouth would establish a full department with Kelly attracting large classes to courses in Polish in translation. Kelly became important in Polish intellectual work but for some reason, despite his popularity, reverted to work in journalism, although he continued his interest in things Polish outside the institution. ${ }^{36}$

All this was at a time when the bulk of the work on East European history was still being carried on in the small institutions by men who had no language training. In far too many places we still can find traces of this habit.

Another important event of the period, following the Bolshevik Revolution, was the arrival in the United States of a number of Russian emigres, on all intellectual levels. Some of them like Professors M. Rostovtseff and A. A. Vasilieff, were among the most distinguished Russian scholars. They easily found outstanding positions for themselves in the leading universities and were able to exert a considerable influence. They brought with them, in various capacities, men like Professor George Vernadsky who were to become the heads of their subjects during the next decades. It would take too long to list all of these men but among them was Professor Leonid Strakhovsky, Rostovtseff's nephew, who taught history at Georgetown University and later moved to the University of Maryland, then to Harvard and is now at the University of Toronto. Professor Serge Eliseeff of Harvard was also in the field of Far Eastern

XXXIII (1941), pp. 242-251; "Die slawische Wissenschaft in den Vereinigten Staaten," Osteuropa, V (1930), pp. 171-176.

ac Kelly left Slavonic studies in 1929 to take up journalism. For details on his career, cf. Who's Who In America, Vol. 29, p. 1380. 
languages. For a while, Nicholas Martinovitch, formerly of the University of Petersburg, was at Columbia in the field of Turkic studies. Many more of the younger group have gradually secured good positions and worked themselves up in the American university system, sometimes with a change of their names.

The same period saw the arrival in the United States of such outstanding Ukrainian scholars as the architect and engineer, Professor Stephen Timoshenko of Stanford University, and his brother the economist Volodymyr Timoshenko of the same institution, and Professor Alexander Granovsky, an entomologist, of the University of Minnesota. Professor Dmytro Doroshenko of the Ukrainian Free University in Prague paid several visits to Canada. All of these men were very active in arousing interests in Ukrainian culture as were the choral leader, Alexander Koshits, and the sculptor, Alexander Archipenko.

There were also a few young men of Slavic origin, born and educated in the United States, who devoted themselves to Russian fields. Among them was Leo Pasvolsky who worked for many years at the Brookings Institute in Washington and was the son of one of the foremost Russian editors in the pre-war United States. Yet the situation was so discouraging that relatively few of the really young emigres who came to the United States after 1918 and secured an education went into Slavic studies. They usually chose some other field and gradually lost all practical influence in the extension of Slavic culture, though in a few cases they did some unofficial work in their own languages.

The situation in the languages and cultures of the liberated Slavic countries was very different. The restoration of the independence of Czechoslovakia and Poland and the formation of the Kingdom of the Serbs, Croats, and Slovenes (later Yugoslavia) involved the "Slavonization" of many institutions that formerly had been under German and Austrian control. As a result, there was a strong call for professors in those lands and very few of the outstanding men came to America during the early years. When they did, it was usually for a limited time, a semester or perhaps a full year, and the funds for this purpose were often supplied by the Slavic community in the neighborhood. Thus the Poles of Detroit brought Professor Thaddeus Mitana to the University of Michigan. This had been intended as the beginning of a Polish chair, but the attempt broke down and Professor Mitana remained at Alliance College, the institu- 
tion of the Polish National Association. Professor Roman Dyboski of the University of Krakow was likewise brought to the University of Chicago for a period, but his lectures were not connected in any sense with the work of Professor Harper. In 1928, Professor Otakar Vocadlo of the University of Bratislava spent almost a full year lecturing throughout the United States. All this did much to promote an appreciation of Slavic scholarship, but since most of the visitors were in technical and scientific fields they did not increase interest in distinctively Slavic subjects.

Many of these visits were arranged through the Institute of International Education which, as part of an international policy, brought to the United States not only professors on lecture tours but many students from the Slavic lands. The same institute also administered a series of fellowships, usually for advanced study, which were chiefly offered to Americans of Czech and Slovak parentage by the Czechoslovak Ministry of Education. A similar program among the Poles was carried on by the distinctively Polish-American Kosciuszko Foundation begun in 1926. It was able to take many American Polish students to Poland by offering them not only free tuition but also greatly reduced rates on the Polish-American line steamships.

During the 1920's those American universities most interested in Slavic subjects developed rather independently. In the field of history, there were few real innovations. During the twenties, and especially during the period of the New Economic Policy in the USSR, a few young men were able, on fellowships from various institutions, to study in the Soviet universities and familiarize themselves with conditions there. Among these men we may mention two important scholars of the present time: Professor Philip Mosely of the American Council of Foreign Relations, formerly of Columbia University, and Professor Geroid T. Robinson of Columbia. Other men similarly visited other Slavic lands for varying periods. Their studies have been an application of the accepted method of historical research to the history of the Slavic countries by men who were as well trained in Slavic as earlier generations had been in French and German.

The situation was different in the field of language, literature and culture, in the general sense of the word, for these subjects had been very largely ignored in the earlier periods except in those institutions where Slavic departments had been established. Even the masterpieces of Russian literature had 
been handled purely on the basis of translations, with few efforts to equate them with the general life of Russia. This had produced the jaundiced view of Russian literature satirized by Stephen Leacock of McGill University. In fact during a large part of the period between the wars, one of the largest groups of students of Slavic literature were persons who had no desire to learn the language or to read Slavic literature in the original. They were merely interested in including Russian in courses of comparative literature, or they were instructors obliged to treat some of the Russian masterpieces in translation.

This broad cultural need was met in different ways by the various Slavic departments. Thus, during these years, the department at the University of California, under Professor George Rapall Noyes, decidedly stressed the development of translation, and courses in which a knowledge of Russian was not primarily required. The department grew steadily but largely maintained its original staff supplemented by visiting lecturers. This policy continued until the eve of World War II. During most of this time Professor Noyes did not make any special effort to establish contacts with the Slavic groups on the Pacific coast.

The situation at Columbia University was different. Professor Clarence A. Manning, who was acting department head during the twelve years which Professor Prince spent in the American diplomatic service, tried to continue the policy of Professor Prince in fostering a study of all the Slavic languages and in establishing contacts with the Slavic communities in the New York area. In terms of administration, the chief development was the transfer of most instruction in the Slavic languages from the faculty of philosophy, where it had originated, to the Columbia Extension Teaching, later revamped as the School of General Studies. This school had been planned originally for adult education but as it acquired a special form it furnished a convenient vehicle for many years, for giving language instruction. For some years it conducted a series of extramural courses, especially in Polish, as far away as Wilkes-Barre, Pennsylvania.

The first addition to what eventually became a full time staff was Mrs. Elena T. Mogilat who, from 1922 until the eve of World War II, conducted practically all the courses in the Russian language. In 1927, Arthur P. Coleman, the first American 
of non-Slavic origin to receive a doctorate in Slavic languages in the United States, was appointed Lecturer and devoted himself chiefly to courses in Polish.

The rest of the staff, some of whom served for many years, was composed chiefly of educated journalists employed on the Slavic papers in New York or persons occupying responsible positions in various institutions of learning and business. Almost without interruption, yearly courses were given in Polish, Czechoslovak and Serbo-Croatian or Slovene. We must specifically mention the courses in Albanian given by Nelo Drizari who published, at this period, an Albanian-English grammar and a small Albanian-English dictionary. Most of the students in these nonRussian courses were second generation Slavs. Few of these ever worked toward higher degrees.

During the twenties, most students for the doctorate were Russians or persons of Russian descent who had come to the United States after the Revolution seeking positions in the American educational world. Those who took the master's degree were largely of the second generation or of non-Slavic origin.

The department made its most extensive efforts in 1929 in providing a summer course on the history of all Slavic literatures. The lectures on Russian were given by Prince D. S. Mirsky of the University of London; on Czech, by Professor Otakar Vocadlo; on Polish, by Professor Kelly of Dartmouth; and, on Yugoslav, by Dr. D. Subotic of the University of London. One lecture on Bulgarian was prepared by Dimitar Shishmanov, the son of the distinguished professor of Slavic philology at the University of Sofia and a well-known Bulgarian author who was executed by the Communists after World War II. The response of students was not sufficient to justify the repetition of the experiment in the next years, although the numbers exceeded anything achieved in England at that time for similar programs.

At the time it was the idea of Professor Manning that the future of Slavic studies, especially in those languages spoken by considerable communities in the United States, lay in the development of interest and support from those communities. This notion was, at the time, warmly supported by Columbia's President Nicholas Murray Butler and led to the formation of an Institute of Polish Culture and an Institute of Czechoslovak Studies. Both met with initial success but the depression with its pressure upon the Slavic population of the United States, led 
to a practical suspension of the institutes after the publication of a Polish number of the American archaeological journal, Art and Archaeology, and a translated Anthology of Czechoslovak Poetry compiled in the United States and Canada.

On the return of Professor Prince in 1933, the name of the department was changed to East European Languages and Professor Prince made a new effort to realize his dream of founding something that would include all of the peoples of Eastern Europe. It proved premature, once again. The department underwent further change after the retirement of Professor Prince. Then in the fall of 1938, Professor Max Vasmer of the University of Berlin lectured for one semester; he was followed by Professor Boris Unbegaun of the University of Strassburg. Still later Professor Karl Menges was added to the faculty to give courses in Slavic and Altaic philology.

In still a different field, Professor Manning and Dean Hawkes, of Columbia College, were both active in the establishment of St. Vladimir's Russian Orthodox Seminary in New York, to train candidates for the priesthood of the Russian Orthodox Church of North America. This developed later into St. Vladimir's Orthodox Seminary and Theological Academy. To this were invited many of the leading emigrant Russian theologians from Paris and elsewhere.

The development at Harvard was somewhat different. Few changes were made in the situation which existed prior to World War I, until the retirement of Professor Wiener. Then in 1927 Professor Samuel Hazzard Cross (born in 1891, A.B. and Ph.D. at Harvard before 1917), rejoined his alma mater and after some years of service in the German department was made, in 1930, Professor of Slavic Languages. With the appointment of Professor Cross, Slavic work at Harvard went through a new period of development and expansion. Into the revised department Cross brought Professor Ernest J. Simmons who had taken his doctorate in 1928 with a study of English influence on Russian literature of the eighteenth century. A larger staff of Russian assistants was also engaged.

Professor Cross, who had translated the Russian Primary Chronicle, stressed the older period of Russian literature, perhaps because of his Germanic interests. He also became the managing editor of Speculum, the organ of the Mediaeval Academy of America. In his interest in the medieval period, Professor 
Cross was not alone in Harvard for from the School of Architecture came the work of Professor Kenneth J. Conant on St. Sofia Cathedral in Kiev and from the English department the work by Francis P. Magoun, Jr. on the spreading in East Slavic lands of the medieval gestes of Alexander.

During the following years, Professor Cross became the center of the developing Slavic activity, which was not limited to Harvard, but which was responsible for the publication of various works in connection with the Pushkin Centennial in 1937. The death of Cross in 1946 was a great loss to AmericanRussian scholarship.

Still another attempt to promote Slavic studies was made at the University of Pittsburgh by the establishment of national rooms in the Cathedral of Learning to serve as centers for the national interests of the students. The Slavic communities, in and around the city, were urged to provide funds to furnish these rooms in native style and appeals were frequently made to the governments of the Slavic countries to help in the work.

In 1927 also, Professor Michael Karpovich, joined the faculty at Harvard as Professor of Russian History. Professor Karpovich had been trained as a lawyer and diplomat in Russia before the Revolution of 1917 and he soon became a leading spokesman for the Russian liberal groups in the United States and in America's scholarly communities.

At the end of World War I, it was proposed that a scientific society be established to unite Slavic scholars. The constitution and practice of existing organizations in history seemed sufficiently broad to include the professors of those subjects but a more complicated situation prevailed in the fields of language and literature.

Consequently, in 1919, there was organized the Society for the Advancement of Slavonic Study. The nucleus of this group was Slavs from various organizations, especially Czechs and Yugoslavs. The first president was Miss Sarka B. Hrbkova who had come to New York from Nebraska after the dissolution of the department at the state university there. The secretary was Leon Zelenka Lerando of Lafayette College. A few meetings were held in 1922 with the final one at Columbia. The society did not prove to be a success, however, largely because of the inability of the founders to realize the aims of the society. It published a few numbers of a bulletin but the addresses at the 
meetings were made largely under the mistaken impression that the "findings" of the society would pass for final pronunciamentos on many of the most disputed subjects of Slavic scholarship. It must be confessed, also, that many of these "findings" were based upon the political decisions made at Versailles and previously advanced by movements such as the Czechoslovak National Committee. As a result, the organization rapidly lost standing and it very soon ceased to exist.

Yet the seed which it had sown was not entirely wasted. In 1922, Professor Manning discussed with the Modern Language Association the possibility of organizing the sclıolars of Slavic languages and literatures under its auspices. From the very beginning, the attitude of Professor Manning and the other founders was to avoid the difficulties that had arisen earlier between the Association and the Society for the Advancement of Slavonic Study. The first meeting, under the chairmanship of Professor Manning, was poorly attended and some of the papers read were decidedly amateurish; but the group continued. During the intervening years, the original group has been developed into two: one for Slavic literatures and one for Slavic philology. The attendance is composed of members of the Association who are either actively or passively interested in Slavic studies. This is very different from the early years when it became necessary to do everything possible to secure an audience for the few persons who ventured to submit papers. During the early years, Professor Manning remained as chairman and the secretary was usually chosen from one of the representatives of the Slavic communities who had shown some interest in the undertaking. Now the posts of chairman and secretary are rotated, more or less regularly, and most professors of Slavic in the country have filled a position at least once. Even so, the group has not sufficiently developed to apply for recognition as a section parallel to those for English, Romance and Germanic. Despite this, one of its members, Professor Ernest J. Simmons, has been elected to the post of Director of the Modern Language Association for one term.

A somewhat different development came in the foundation of the Slavonic Review by Professor Sir Bernard Pares and Professor R. W. Seton-Watson at the University of London in 1922. From the beginning, this journal, the first purely scholarly Slavic journal in English, had as American co-editors, Professor Harper, Professor Noyes and Professor Kerner, then at the Uni- 
versity of Missouri. In 1923, once the journal was fairly launched, Professor Seton-Watson came to the United States in the hope of dissuading American Slavists from starting a competing journal. The proposal was broached at a meeting of the American Historical Association in Richmond, Virginia, but was decidedly disapproved by some of those present, and the idea was tacitly dropped without prejudice to the cooperation between the scholars of the two countries.

In a somewhat different vein, mention should be made of the monthly magazine Poland. This was started in 1919 by the Polish Legation in Washington at the suggestion of the Baldwin Locomotive Works which had taken a prominent part in the rehabilitation of the Polish railroads after World War I. The Baldwin company furnished the permanent staff, an editor, Paul Le Tallec, a young Frenchman, and Eric Lord as business manager. The journal received a subsidy from the Legation. It was started purely as a trade journal, but Le Tallec had other views. Under Clarence Dawson, who succeeded Paul Le Tallec as editor, it rapidly developed into a general magazine covering all aspects of Polish life, art and literature, as well as economics and business. The journal proved successful for over ten years but when Dawson resigned as editor, it began to fail. The magazine changed its character considerably and finally, in the early thirties, was allowed to lapse.

It was during this same decade that energetic work was done in building the libraries of various institutions. Even before the Russian Revolution, the Library of Congress had acquired a large, uncatalogued collection of Russian books and the New York Public Library developed a very large and extensive Russian department. There were large Russian collections at both Harvard and Yale. At Columbia, the Russian collections prior to 1914 were negligible, while at the University of California, Professor Noyes had specialized largely in translations of Russian literature. Most of the institutions took advantage of the large number of Russian books that were thrown upon the market after the Soviet Revolution and purchased whole libraries from emigres and other sources.

The Columbia collections were increased by the gift of a large library on Russian literature, collected for many years by Dr. Samuel Abel, a graduate of the College of Physicians and Surgeons. It numbered several thousand volumes. The establishment of the Hoover War Library at Stanford University brought 
to that institution a vast amount of material, especially concerning Slavic countries, that had been collected by American Relief workers, under the direction of Herbert Hoover.

We must also mention the work that developed at Georgetown University under the direction of Father Edmund Walsh who had served in Russia after the Revolution. Work was done in the various schools but especially in the School for Foreign Service of which Father Walsh was the founder. Georgetown's example was seconded by the continual improvement in the standards of other institutions such as that of the Czech Benedictines at Lisle, Illinois, and further, by the establishment, in 1933, of such institutions as St. Basil's College in Stamford, Connecticut, by the Ukrainian Greek Catholic Exarchate of Philadelphia.

There was also a large number of Slavic books and translations from Slavic in the public library in Cleveland, Ohio, where Mrs. Eleanor Ledbetter had worked long and hard with the Slavic groups in that city. Thus, by the outbreak of World War II, there were in the United States a considerable number of libraries that were fairly adequate in nearly all the centers where Slavic subjects were treated with the importance that they deserved.

In 1931 work in Russian literature in English was also started at the University of Washington, in Seattle, by Ivar Spector. In 1943, a course in Russian history was added. In addition to these courses, Professor Spector did considerable lecturing before various groups interested in Russian affairs. The interest in Seattle is especially noticeable because of the possible contacts with Siberia across the Pacific ocean. Whatever contact is had with the Soviet Union comes almost inevitably through the seacoast cities on the Pacific Ocean. The same motives have led to a strengthening of Russian work in the other California universities, the University of California at Los Angeles and the University of Southern California.

Strange to say, the recognition of the Soviet Union in 1933 by the United States did not produce a marked increase in interest in Russian Slavic affairs. Student interest flagged and it was soon evident that the need for Russian in the business world would not at all parallel the situation which a few years earlier had sparked the great development in Spanish studies.

The years of the depression, in many ways, produced another period of marking time in Slavic studies. For the most 
part efforts of the Slavic groups to introduce their languages into the American educational system were retarded, while available finances were restricted to relief purposes. In other cases, as among the Czechs, the hardships were complicated by the death of such leaders as Reverend Vincent Pisek and Professor Michael Pupin who had been active in stimulating cooperation between the immigrant communities and the American educational system. Their deaths at a critical period disrupted much of the work. Further, the 1931 failure of the Bank of Europe Trust company in New York under conditions which almost completely reimbursed the depositors, nonetheless lessened the effectiveness of Thomas Capek, a leader in the work. Similar disasters in other Slavic groups had similar nation-wide effects and except for an effort to interest the Czech population in the Chicago area to establish courses at the University of Illinois, the period was destitute of that type of energetic development which, on the eve of the depression, promised to bear such rich fruits.

In a lighter vein came the establishment of courses in Russian under the NRA. It had been hoped by some that it might be possible to give relief to at least some of the unemployed Russians by the establishment of free courses in the language. The attempt was almost completely a failure. The students lacked any serious-desire to learn the language and the instructors were no more anxious to teach it. One very well educated Russian actually prepared a set of charts on Russian grammar which purported to show that there were no exceptions to any syntactical rule in Russian and he blandly presented to his class word forms that he knew never existed even in the speech of the most illiterate. When he was reprimanded, he calmly told the NRA supervisors that he knew that none of his students intended to learn Russian, he wanted his money, and so there was no reason to worry about what, or how he taught.

In 1934, a new development emerged which was to prove exceedingly fruitful in later years. Largely under the influence of Professors Cross and Patrick, a small sum of money was secured to establish an intensive summer course in Russian for about 20 students. The course was held at Harvard University the first year and was directly under the control of Professor Patrick who had come from the University of California to conduct it with the aid of some assistants. The experiment was successful. In 1935, joint sessions were held at Columbia Uni- 
versity and were to a certain degree independent of the regular summer school courses. Professor Patrick was assisted by Mrs. Mogilat of Columbia and Dr. Jack A. Posin of the University of California. After 1935, the course was held at the University of California, largely because of the increasing illness of Professor Patrick.

The session at Columbia was attended by two regular officers of the United States Army, Major Frank L. Hayne and Lieutenant (later Brigadier General) Joseph A. Michela. Their attendance was made possible by the efforts of Colonel Burnett, officer in charge of the Military Attache Service, who, having served several terms as United States Military Attache in Japan, insisted that officers assigned to such posts as Moscow and Tokyo have a speaking and reading knowledge of the local language. This had been the case of Colonel Philip Faymonville, the first Army man to be sent to Moscow after the restoration of diplomatic relations between the Soviet Union and the United States. In a sense, it was almost the beginning of serious language work by the United States Armed Services. Both Hayne and Michela later were military attaches in Moscow, although Hayne was transferred to Finland during the Soviet-Finnish War. Michela remained in Moscow during the greater part of the War and participated in the removal of the capital to Kuybyshev when the Gremans approached Moscow in the summer of 1941. At Columbia, these officers had special courses during a two year period. In the second year they were joined by Captain Ivan Yeaton, who had previously served during World War I in the Siberian Expedition under General Graves. Other officers were later added to the group but as World War II approached, the entire project was transferred to Harvard University.

The thirties also witnessed the beginning of a systematic interest in Russian studies by the American Council of Learned Societies. This group had previously considered the need for developing studies in specialized fields and had approached foundations to secure money for limited projects. It had been successful in fostering work in Chinese and in completing at least a preliminary survey of American resources in the field. It then turned its attention to Russian and established a committee to study the general status of Russian studies. Professor Cross was secretary of this important committee for several years. Through the activities of the American Council, coordina- 
tion of work by the various universities and colleges, was accomplished. This was but the beginning of a process which was to be greatly intensified during the War.

In the thirties, the University of Wisconsin began to offer courses in Polish. Elaborately planned, Professor Joseph Birkenmeyer from the University of Krakow was invited to direct the work. Unfortunately, he returned to Poland just on the eve of World War II, but the work was continued successfully. ${ }^{37}$ The department at Wisconsin was established primarily through the influence of the Polish population of the state.

When we consider the state of affairs as a whole on the eve of World War II it is apparent that no important university or college had established an adequate course in Slavic languages and literatures other than those which had done so by the end of World War I. This does not mean that the period between the wars was lost. The departments at all the major centers were better equipped than they had been twenty years before; they had larger libraries, better trained instructors and what is more, they were attracting more serious students. Further, there were, in the United States, a considerable number of men who had had personal experience and acquaintance with the Slavic and adjacent countries. There were real experts in almost every field of Slavic studies and there had been a large output of books on the languages, literatures and histories of the Slavic nations.

Of course, Russian predominated. Yet is is noteworthy that during the twenties and thirties when American institutions were overrun with would-be Communists, the Slavic departments, which might have seemed the most vulnerable, somehow escaped with the least amount of trouble. They had not taken sides in the fervent polemics of the period that were carried on with more heat than light, and while there were a number of men who had studied or visited the Soviet Union, few, if any, had become seriously infected with Communism.

They had, however, continued to repeat the old traditional formulas set out by Russian scholarship before the Revolution, arbitrarily neglecting all aspects of the nationality problem in the Soviets, treating Russia as a single unified country, without regard for the mixed elements of her population or the Soviet divi-

${ }^{97}$ Bulletin of the Polish Institute of Arts and Sciences in America, I, p. 161, carries the obituary of Joseph Birkenmeyer. 
sion of the republics by an official policy of differentiation between the peoples.

The most unsatisfactory aspect of the period concerned the non-Russian Slavic tongues and histories. This was unfortunate, for it tended to give instruction in the major centers a Russian, if not Soviet, orientation, a fact which would cause repercussions in the following period.

Among the Slavic communities, some leaders were beginning to understand better the peculiar problems of the American educational system, and though they had not yet come to cooperate actively, they were rapidly becoming aware that there was serious work being done. Their own institutions were improving. They were securing more American-trained teachers, even if they were members of the groups, and many second generation Slavs were rising to prominence.

Thus, the period represented a marked deepening, rather than an expansion, of efforts. Slavic languages and history were no longer considered merely artificial and exotic; the way was cleared for a period of rapid expansion. 


\section{SLAVIC STUDIES SINCE 1939}

IN THE PERIOD OF TENSION which followed the Munich Agreement of 1938, the opening of World War II, and the period of Nazi-Soviet cooperation, Slavic studies in the United States, as well as the studies of the neighboring East European countries began to receive more serious consideration. A period of more active interest began. Because developments during World War II have continued since the ending of hostilities, it is difficult to draw a hard and fast line between the War and post-war period, largely because of the Cold War and the establishment of the Iron Curtain or, better yet, the recognition that there were tremendous gaps between the thinking of the Western free world and the Soviet dominated areas.

On the surface, the reactions in 1939 differed little from those in 1914. This is well illustrated by the fact that at the annual opening exercises of Columbia University in 1939, President Nicholas Murray Butler repeated large extracts from his talk of 1914 on a similar occasion. Yet, the attention of the American public was more sharply focused on events in Eastern Europe than it had been in 1914 and the colleges and universities during the preceding twenty-five years had provided a larger nucleus of trained men. The events of the first months showed, however, that far too many of these trained men were still bound to the thinking of the past and were not prepared to take into account recent developments on a global, and even on an East European, scale. Such short-sightedness prevented adequate consideration of the situation as it unfolded day by day.

The old myth that Russia was a single country inhabited by a single people, with boundaries defined long ago, proved remarkably vital. President Wilson's formulation of a Russian policy in 1918, recognizing the need of the Russian people to choose their own form of government, was still accepted and even the colleges and universities paid little attention to the structure of the Soviet Union as it saw itself. The American 
people and their government continued to use the word Russian as a synonym for Soviet Union and were puzzled, as they had been in 1917, by the movements that arose in the territory. As in 1917, Finland stood out as a distinct nationality, but the popular reaction to the annexation of the Baltic republics was marked as much by confusion as by indignation. Supposed "experts" even found grim relief in the fact that after 1939 the borders of Germany and "Russia" were touching and this seemed to confirm the validity of the pre-1914 frontiers.

Thus the crisis tended to emphasize again the importance of Russian history and the Russian language. In a sense this was justified. The force of events had made the Russian language predominant in Eastern Europe and the leaders of the USSR were almost exclusively Russian, except the Georgian Stalin, who regularly espoused the Great Russian cause for foreign consumption. All tendencies to stress the opponents of Moscow and their cultures ended abruptly with the Nazi attack on the Soviet Union and continued in the following period of Sovietdemocratic cooperation. Such emphasis on the Russian character of the USSR was furthered by many of the Russian emigres, who at the height of the war, were only too ready, whatever their political convictions, to serve the cause of Mother Russia, a policy which was fostered by Stalin's clever use of Russian slogans.

Many British and American authorities zealously compared the German attack on the Soviets in 1941 to the German advance in 1918 after the Soviet Revolution. A bitter propaganda attack was started, both inside and outside the universities, against all national groups from the old Russian empire having separatist aspirations. The old equation that all who were not pro-Communist were pro-Nazi was repeated, especially after 1941. The Ukrainians received the worst criticism but they were not alone. Even though the United States government refused to recognize the seizure of the Baltic states, President Roosevelt acceded to the demands of Stalin and allowed him to sign the Atlantic Charter. They did not grant this to the representatives of the occupied countries, lest they break the friendship with that great anti-Nazi power-"Russia." Under such conditions, lectures arranged by Professor Manning at Columbia University in the spring of 1941, with the aid of the Ukrainian National Association and a number of distinguished professors of Eastern 
Europe, evoked severe criticism from many anti-Nazi radio commentators who followed the whims of popular sentiment.

The chief counterweight to this tendency was the arrival in the United States of many distinguished scholars who had escaped the holocaust of Nazi rule and the direct impact of Soviet power on Slavic scholarship.

The circumstances of the peaceful occupation of Prague in the spring of 1939 made it difficult, if not impossible, for many Czech professors to leave. The chief exceptions were Professor Otokar Odlozilik and Professor Roman Jakobson who were outside the country when the storm struck.

The Poles were more fortunate, for during the crucial weeks of the destruction of Poland, many of their leading scholars had been able to escape north into Lithuania or south into Romania, from which countries they made their way to the west. When they arrived in the United States, the Polish organizations, working with the Polish Legation in Washington, found funds to allow them to continue their scientific work. To furnish a center for them and keep them from being lost in American life, an American branch of the Polish Academy of Arts and Sciences in Krakow was formed under the distinguished historian, Professor Oskar Halecki. This was later reorganized as the Polish Institute of Arts and Sciences in the United States. During the war years, it received sufficient funds to publish a quarterly journal, the Bulletin of the Polish Institute of Arts and Sciences in America, and to issue several scholarly works on Polish subjects. Still later, when the Germans pushed westward, other Polish scholars, such as Professor Waclaw Lednicki and Professor Manfred Kridl, succeeded in reaching the United States. Most of these men have since found places in the American scientific world.

Few distinguished Russian scholars arrived at this time and there was only one Ukrainian, Professor Nicholas Chubaty, who almost by accident, arrived in the United States for a meeting of Pax Romana, an international organization for social action under the auspices of the Catholic Church, and remained here after the outbreak of hostilities. The Southern Slavs and Bulgarians fared even less well.

War produced, at first, relatively little effect upon Slavic studies as a whole or Russian in particular. It was not until 1940 that there came any appreciable increase in the number 
of students. Yet the general reaction of the public differed from that of 1914. Despite the growth of anti-Nazi and even antiGerman feeling, there was no attempt to exclude German from the curricula of any important institution. There was no decline of students, but rather an increase. The same was true of Russian, and long before 1941, the governing bodies of institutions without Slavic departments began to think of introducing them. We can only mention certain instances of this development. ${ }^{38}$

Professor Alfred Senn, a Swiss philologist from the University of Kaunas, who held several positions in other institutions, became Professor of German Philology at the University of Pennsylvania in 1938. During World War II, he offered courses in Russian, and in 1948 became Professor of Balto-Slavic Philology and head of the Department of Balto-Slavic Studies. As such, he was able to group around him a number of refugee scholars.

In 1939, Cornell University invited Dr. Jack Posin to teach Russian and in 1941 named Ernest J. Simmons Assistant Professor of English and Russian. In 1942 Simmons was named chairman of a newly established department of Russian, and, in 1945, was promoted to a full professorshíp. Dr. Posin, meanwhile had transferred to the University of Iowa, in 1942, as Assistant Professor of Russian.

At Syracuse University, Professor Albert Menut of the Department of Romance Languages, a student of Russian, was able to develop courses in Russian and to inaugurate a Russian program.

The extent of Slavic development during this period is revealed in a survey conducted by Professor Arthur P. Coleman in 1945, which showed eighty-one institutions offering courses in Russian and eleven in Polish. At the same time, there were 147 schools and colleges offering courses in Slavic history and culture. The increased interest in history seems all to the good, but it can be noted that well over fifty institutions offering work on Russian and Slavic subjects lacked collateral courses in the languages. This, however, was a far smaller proportion than existed in 1914. Furthermore, it was not a peculiarity of the United States, for as late as 1924 in Germany there were professors of East European history who looked askance at students wasting 
their time on linguistic studies, for they preferred to have them work from translations.

To secure a staff for the American expansion, particularly in Russian, offered many difficulties. There had been almost no immigration of Russians for many years and the bulk of the possible instructors were persons who had come to the United States shortly after World War I. These were the only ones with any special training, for during the period between the wars, few young Russians from educated families had seriously considered doing advanced work in Russian, even though there were many with knowledge of the educational system. An outstanding exception was Oleg Maslenikov who, at this time, joined the staff of the University of California.

The chief emphasis, in this period of expansion, was on a speaking knowledge of the language. Wherever it was possible, instruction was begun under the supervision of some member of the faculty with a knowledge of Russian, while much of the actual work was done by native assistants. This combination, originally applied to Russian by Professor Patrick, became the general rule and was successful where it was intelligently used.

Unlike the situation in World War I, the United States government actively encouraged these studies and assigned draftees as well as volunteers to special units for the study of languages, and special language schools were established for the Armed Services throughout the country. This created still another problem. Wartime conscription reduced the number of students alarmingly causing nearly all colleges and universities to become dependent upon government funds for their continued functioning. The larger institutions, with their highly developed laboratories and opportunities for scientific training, received most of the students to be trained in technical subjects. The government, therefore, of ten opened language centers in smaller institutions, many of which lacked necessary libraries and, in some localities, secured a proper staff of instructors only with difficulty. Thus, Bulgarian was assigned to the University of Denver, which was fortunate to find in that city an educated Bulgarian lady. She agreed to help, although she had never seriously considered teaching Bulgarian, and was compelled to prepare most of her materials from original Bulgarian texts which she owned.

With the reduction of the armed forces after the War, many 
of these courses were suspended, although both the Navy and Air Force still send selected students to various universities. The Army, however, has established its own language school at the Presidio of Monterey. With a well selected civilian faculty, many of them former members of university staffs, this is rapidly becoming one of the best institutions of its kind for the study of the Slavic as well as other languages. It is preparing, for its own use, its own courses and it promises to become an important testing ground for Slavic and East European studies. In addition to this, Russian has been introduced into the curriculum of such service academies as West Point, where the work which was tentatively started after World War I is now on a definite and secure basis.

This period, too, saw the beginning of the organization of the so-called area studies. In these, the history, geography and economics of the given area are stressed. Such efforts represent an attempt to overcome the gaps which have developed between historical, literary and cultural studies through the departmentalizing of institutions. But as they have developed, historical and economic elements have been stressed more than cultural and literary. This was perhaps natural. However, during the War, at the height of the enthusiasm for the USSR, studies of this kind tended to accent the Soviet version of the relations between the nationalities of the Soviet Union, and the old Russian concept of a single Russian people. There was thus, a perpetuation of the previous confusion in American thinking; and, it was not overcome even when the Ukrainian and the Byelorussian Soviet Socialist Republics were included as charter members in the United Nations.

The greatest single deterrent to Slavic study was the almost simultaneous death of nearly all the older leaders of Slavic scholarship. To list but a few of the more prominent: Professor John Dyneley Prince, who had retired from Columbia in 1937, died in 1945 at the age of 77; Professor Alexander Kaun, of the University of California, died at the age of 55 in 1944; Professor George Z. Patrick, of the same institution, died at the age of 63 in 1945; Professor Henry Lanz, of Stanford, died in 1945 at the age of 59; Professor Samual Hazzard Cross, of Harvard, died in 1944 at the age of $55 .^{39}$ Thus, within three years

3n Obituaries of these leaders appear as follows: Prince, American Slavic and East European Review, IV; Cross, ibid., V; Lanz, ibid., IV; Patrick, ibid., IV; Kaun, ibid., IV. 
practically all the older men in the field of Slavic literature died except Professor George Rapall Noyes and Professor Manning. The losses in history were not so severe but Professor Samuel N. Harper, of the University of Chicago, died in 1943 at the age of 61. As a result Professor Robert J. Kerner, for many years at the University of California, was the only person remaining in the field of history who had become prominent before 1914. This, in a sense, sharply delineates the earlier period of Slavic studies. Today the leaders of Slavic scholarship belong definitely to a different generation, one which is certainly better trained but does not necessarily have the range of interests which often marked the older men.

Another, somewhat different, development needs to be noted. During the first years of the War, when England was severely strained by the war and the bombing of her cities, it seemed that the Slavonic and East European Review would be compelled to suspend publication. To meet the crisis it was decided that the journal would continue under the direction of the American contributing editors. Thus, until his untimely death, Professor Cross was the practical editor of the magazine, assisted by Professor Leonid I. Strakhovsky. Issues appeared with both an American and British volume number. After the War when the British expressed a desire to resume publication, the American editors expanded their numbers and, with the aid of the Joint Committee on Slavic Studies, established the American Association for the Advancement of Slavic Studies to publish The American Slavic and East European Review. The present committee of scholars in charge of the publication is Professor Abram Bergson of Harvard; Professor George B. Cressey of Syracuse; Professor H. H. Fisher of Stanford; Professor Alexander Gerschenkron of Harvard; Professor Oskar Halecki of Fordham University; Professor Roman Jakobson of Harvard; Professor Michael Karpovich of Harvard; Professor Robert J. Kerner of California; Professor W. Lednicki of California; Professor Philip Mosely of the Council for Foreign Relations; Professor Geroid Robinson of Columbia; Professor Alfred Senn of the University of Pennsylvania; Professor Ernest J. Simmons of Columbia; Professor S. H. Thomson of the University of Colorado; Professor George Vernadsky of Yale, and Professor Francis J. Whitfield of the University of California. Nothing better illustrates the way in which Slavic studies has developed than this list, for the overwhelming 
majority of these scholars represent those institutions where departments had existed before World War I.

The American Slavic and East European Review is the leading publication in the United States for Slavic studies. However, other journals, such as the Publication of the Modern Language Association, Speculum, the Journal of Central European History (edited by Professor S. H. Thomson) and the Journal of East European History (edited by the University of Chicago), also contain specialized articles. As a matter of fact, there are very few of the more specialized journals which during the past years have not included articles on some aspect of the East European historical and cultural world.

There are also several quarterlies published in the United States which deal with East Europe. Among these are: The Russian Review, edited by Professor D. von Mohrenschildt of Dartmouth College, originally founded with the aid of the Russian Student Fund; the Ukrainian Quarterly, edited by Professor Nicholas Chubaty for the Ukrainian Congress Committee of America; and, the Polish Review, published by the Polish Institute of Arts and Sciences in America. We may also place here the Armenian Review, edited by Mr. Reuben Darbinian for the Hairenik Association (Boston, Mass.). These are scholarly journals devoted to the language, culture and history of the people for whom they are compiled, which cannot be overlooked in any survey of the intellectual output for East European subjects. There are also many smaller organs and bulletins of societies, often with world wide connection, which serve a more specialized political program. They are important for their frequent opposition to the accepted viewpoint of history and culture, but are essentially more political than scholarly in its content. As has been stressed again and again, Slavic studies have developed so largely under the influence of the imperial Russian and German traditions that truth has often seemed to be merely what was decided in pre-World War I St. Petersburg and Berlin.

The Slavic group of the Modern Language Association of America is still the leading scientific center for philologists and students of literature in the broadest sense of the word. It holds a yearly meeting, concurrent with the Modern Language Association, and is divided into two parts, literary and philological. It offers the best possibilities for the developing of personal con- 
tacts among more serious students. In time it should become a section parallel to that of the English, Romance and Germanic sections but the day when there are sufficient members is still in the future.

For many years there was no special section in the American Historical Association and its allied societies, devoted to the study of Slavic or East European history. This did not mean that the subject was ignored, for numerous papers were included in the regular program and, many times there were entire meetings devoted to Slavic problems. However, in 1955 a special conference on Slavic and East European studies was formed to provide continuity and concentration in the subject. This activity will undoubtedly expand in future years.

Another organization serving Slavic scholars is the American Association of Teachers of Slavic and East European Languages, formed by Professor Arthur P. Coleman, formerly of Columbia University and now president of Alliance College. Founded in 1941 to parallel such groups as the American Association of Teachers of German, this organization exists to bring together teachers of the subject, rather than to promote research. The association is divided both by languages and by localities. It has appealed to many emigre scholars, and this has led it to a more definite anti-Communist position than many other groups, which have often leaned over backward to appear impartial and unprejudiced. It has now established the Slavic and East European Journal.

The ranks of emigre scholars, which had started to grow with the arrival of many Poles in 1939, were augmented after 1945 by the arrival of many displaced persons. These men, for the most part Ukrainians and often of considerable intellectual stature, found themselves in an unenviable position chiefly because of their inability to speak English. The majority were already mature or even elderly. They had escaped the holocaust caused by that interpretation of the Yalta agreements which had led to the forcible return of many refugees to the Soviet Union. However, they were aided by their own ability to make the most of opportunities given them by the freakish events of the last months of the War in Europe. In and out of the DP camps, they had created their own scholarly groups in Germany and Austria. Thus, the Ukrainian Free University which had been established first in Vienna and then moved to Prague after World 
War I, was now reopened in Munich. An UNRRA university was started in the same city. A less formal Baltic university was established in Hamburg in the British zone. At one time there were plans to transfer this latter institution to Canada, but the plan miscarried. However, many of the leading professors of these institutions have come to the United States and Canada and are being absorbed into the American educational world. In the beginning, many of these men were compelled to take non-intellectual positions. Others found places in institutions (usually Catholic, of either the Western or Eastern Rites) educating their compatriots, at schools such as Alliance College, and the Ukrainian Catholic St. Basil's College in Stamford, Connecticut. ${ }^{40}$

In addition to these institutions, the displaced persons opened many more elementary schools on all educational levels to train their fellow countrymen whose education had been interrupted by the War and the limitations imposed on general education, both by the Soviets and the Nazis.

By a series of fortunate coincidences, the majority of the administration of the old Shevchenko Scientific Society in Lviv, and a large part of its membership were saved in the DP camps. There, this society, which had been suppressed by the Soviets in 1939 after their occupation of Lviv, was again revived under the same officers in Munich. The center was later moved to Sarcelles near Paris. Many of its members have come to the United States, and while the headquarters are still in Sarcelles, American and Canadian branches have been established in New York and Toronto and are working actively, publishing the results of their studies in both Ukrainian and English.

At about the same time, other Ukrainians in the camps, perhaps more often from eastern Ukraine, formed the Ukrainian Free Academy of Sciences. Its members have also come, in numbers, to America and are functioning in New York and Winnipeg. They publish the quarterly Annals in English, greatly aided by the East European Fund set up by the Ford Foundation.

These two groups, which parallel the Polish Institute of Arts and Sciences in America, have counterparts in the Francis Skorina Society (Kryvian), and the White Ruthenian Institute of 
Arts and Sciences in the U.S., the Croatian Academy of Liberal Arts and Sciences, and the Serb National University in Chicago. The Masaryk Institute, formed by a group of Americans and Czechs before the Nazi occupation of Czechoslovakia, is in a sense similar but it has also the features of the Kosciuszko Foundation. It is too early to know what position these societies will take in Slavic programs of the future, but their outstanding individuals are securing recognition in American colleges and universities. Whether they will ultimately form a branch of this general educational field or whether they will develop into more highly specialized groups drawing upon interested Americans of non-Slavic origin, cannot now be answered with certainty. Some of them are undoubtedly ephemeral but some have had a long cultural tradition and can be expected, in their new environment, to exercise an influence out of proportion to their numbers.

Many of the newly arrived scholars are already playing an important role in the development of Slavic studies and in the reorganization of some of the older departments. It would take too long to list all who have found important posts. Professor Oskar Haleçki is developing the study of Polish history at Fordham University. Professor Roman Smal-Stocki at Marquette University has taken a prominent part in the formation of a Slavic Institute there. By such publications as The Nationality Problem of the Soviet Union, he is helping acquaint the American public with the dangers of open, as well as secret, Communism in the United States, besides exposing the inaccuracy of the American concept that all citizens of the former Russian empire are Russians by blood, feeling and culture. There is, in addition, the work of Professor George Shevelov in comparative philology at Columbia University, and that of Professor Dmytro Chyzhevsky at Harvard, which emphasizes the older Ukrainian literature.

The rise of recently arrived Slavic scholars and the influence of transplanted organizations of Slavic scholarship was earnestly needed by American Slavic scholarship and, in fact was forced by the surprising number of deaths during the war period. Development in the different institutions has been conditioned, of course, by the general traditions and spirit of each school. While growth has been rapid, it cannot be said that all results have been unqualifiedly happy or successful, partly because of the sporadic interest by both faculty and students in the field as 
a whole. Slavic subjects (not to speak of the closely associated non-Slavic languages like the Ural-Altaic groups, modern Greek and Romanian, all of which have strong Slavic overtones) are extremely broad and diverse. Yet for the average American student, Slavic and Russian are too exclusively identified. Even interest in Russian has been chiefly limited to either pure philology or, more frequently, Russian literature of the nineteenth or twentieth centuries.

As an example, consider Columbia University's efforts to secure a balanced course. When Professor Ernest J. Simmons joined the staff, in 1946, as professor of Russian literature and Chairman of the Department of Slavic Languages, as it was now renamed, he hoped to build a broad program. The department was informally divided into four sections: Slavic and Russian philology; Czech and Slovak; Polish, and South Slavic. To help defray expenses, the university, reversing the policy formulated by President Butler after the unpleasant developments of the World War I period, sought from the lesser Slavic lands, a yearly subsidy to pay the salary of a distinguished professor. This was easily secured from both Poland and Czechoslovakia and Professor Roman Jakobson was appointed the Thomas G. Masaryk Professor of Slavic Philology, and Professor Manfred Kridl was named the Adam Mickiewicz Professor of Polish. Arrangements were made without considering developments which might be caused by the Communists, and similar agreements were unade with many countries of the Near and Middle East. The experiment was hardly satisfactory. After the Communist coup in Czechoslovakia, the new regime imposed such conditions that maintenance of the chair was impossible. Poland more slowly followed the same course. Despite other arrangements with less possible political interference, made by the university, the number of students in the Czech, Slovak, Polish and South Slavic sections of the department has been scarcely larger than it was between the wars. There was no attempt, at Columbia, to break the traditional separation between the faculties of philosophy and political science, or establish a single department for all Slavic, or even all Russian, instruction. Russian history, under Professor Geroid Robinson, continued to develop as it had, just as other areas of study continued under the faculty of political science.

Development at Harvard was somewhat different. There, 
after the interim period following the death of Professor Cross, Professor Roman Jakobson came to Cambridge in 1949, with a number of experts in Slavic fields. At about the same time, work in all Slavic subjects was, at least partially, consolidated and Professor Karpovich was named to the Curt Hugo Reisinger Chair of Slavic Languages and Literatures, in addition to his work in history.

At the University of California development was severely affected by the death of Professors Patrick and Kaun, until the staff was rebuilt by the appointment of Professor Gleb Struve and Waclaw Lednicki, and the promotion of Professor Oleg Maslenikov. ${ }^{41}$ There was no attempt to integrate the work in history under Professor Robert J. Kerner, although the department broadened with an increase of students.

In the same period, Slavic studies at Catholic universities, especially those administered by the Society of Jesus, have been greatly strengthened. While Georgetown University, alone, achieved standing in language instruction following World War I, the situation has changed since World War II and Fordham, Notre Dame, and Marquette are all setting new standards in the range of courses offered and in the thoroughness of their work. These institutions have also contributed by studying the contrasts and similarities between the Russian Empire and the Soviet Union, with emphasis on the nationality problem of Russia-USSR. Numerous conferences have been held and addresses have been published.

Marquette University, located in Milwaukee, Wisconsin, where there is a considerable population of Slavic descent, has established a Slavic Institute under the direction of Professor Roman Smal-Stocki. In the announcement of its first publication, The Doctrine of Anarchism of Michael A. Bakunin, the Institute stated its goal:

... to strengthen the knowledge of Slavic matters and problems in America through this special series of monographs on Slavic nations, their history, culture, civilization and their great personalities. Simultaneously we would like to cultivate through original research, the Slavic heritage of more than twelve million of America's citizens. According to our anniversary motto, we dedicate the series to the

${ }^{41}$ Noyes, "Slavic Languages at the University of California," Slavonic Review (American Series III, 1944), XXII, pp. 53-60. 
"Pursuit of Truth to Make Men Free" and in this spirit we shall approach all Slavic nations, large and small, with a deep sense of their fundamental equality, disregarding all Slavic imperialisms and colonialisms, and with a warm respect for their fine heritage, which has become a component part of our American culture and civilization.

Scholarly purposes of this sort, which respect the culture of the Slavic peoples apart from political dominations, and the avowal to study changes of Slavic culture in the New World, bid fair to mark a new era for such studies.

Leading American colleges as a whole have introduced Russian into their curricula. Most courses are taught by men trained while in American government service during World War II, who have continued their preparation in graduate programs at one of the longer established Slavic departments. ${ }^{42}$

Much of the recent development in Slavic scholarship must be credited to the work of the Joint Committee on Slavic Studies. Started before World War II by the American Council of Learned Societies, a committee was established in the Slavic area, based on the prototype which existed to aid the reorganization and development of studies in Chinese. Later the Social Science Research Council established a committee for the development of Slavic studies in the social sciences. The committees of these organizations combined to form the Joint Committee, which was able to secure large subsidies from foundations for the development of courses, faculty salaries and scholarship grants.

The initiative of this committee, working with influential and alert university officials, has aided the expansion of wartime area-studies into institutes, organized programs and centers of research and training. This approach to academic organization is, in a sense, borrowed from European university organization which used institutes, such as the Slavic Institute in Prague, as a means of coordinating the activities of previously isolated chairs. In the United States, where the organization of courses led to the establishment of cohesive departments, the institutes became a means of coordinating departments which were in different faculties, sometimes in isolation and even competition, 
especially in courses on national cultures which almost of necessity impinge on history.

In addition, the institutes had a more practical side, for along with the development of pure research, they aspired to supply trained men and women for special technical work in both government and civilian enterprises. We can scarcely summarize this activity better than by quoting the purposes of the Russian Institute as reported in the Announcement of the Faculty of Philosophy of Columbia University, for 1957 (p. 146):

The Russian Institute, established in 1946 with the assistance of the Rockefeller Foundation, has two major objectives: the development of research in the social sciences and the humanities, as they relate to Russia, and the training of a limited number of well-qualified Americans for scholarly or professional careers, as Russian-Soviet specialists in business, in finance, in journalism, in various branches of government service, and in academic research and teaching in the social sciences and in literature. It is believed that such prospective specialists should acquire (a) a broad and thoroughly integrated knowledge of Russia and the Soviet Union; (b) command of a well-developed specialty in a selected academic discipline, as applied to that country; and (c) a broad training in the more general aspects of this selected discipline. To this end, each candidate for the two-year certificate will pursue certain survey courses on Russia, while giving special emphasis, within the Institute, to one of five fields: Russian history, economy, government and law, foreign relations, the social and ideological aspects of literature. At the same time, the candidate will be expected to follow outside the Institute, a parallel program of work in the graduate school or department of the University that is most closely allied with his Russian specialty within the Institute.

All of these institutes, wherever they have been founded and whether they are Institutes, Studies or Programs have been faced with the same fundamental dilemma: how is the term "Russia" to be defined? A certain number of scholars, who have been labeled by Professor Lev Dobriansky of Georgetown University as the "Russia Firsters," have stubbornly insisted that it was their duty to devote themselves to the study of Russia in the traditional sense of the word, i.e. the consideration of Russian 
culture, history and economics without regard to the linguistically and culturally heterogeneous character of the old Russian empire. To students of this school, every person within the old Russian empire is a Russian, whether their studies concern economics or concentration camps. They refuse to separate the statistics in any way that might show increased pressure on the non-Russian peoples by the Soviet government. They feel themselves free to do this, even though Stalin himself after World War II specifically attributed the victory of the Soviet Union to the loyalty of the Great Russians, i.e. Russians in the narrower sense of the word.

This attitude, despite the prominence of its supporters, has been steadily opposed by those students who stress the cultural and linguistic differences which existed in the old Russian empire as well as in the modern Soviet Union. These students emphasize the similarities between the Russian and Soviet concepts of dominance of the Great Russians, and argue for a proper recognition of the oppressed nations of the USSR who sought their independence during the Revolution and have since been restrained by force of arms to adopt Communism. They accordingly see in the restoration of the political independence of these nations the best answer to the Communist menace to freedom. This viewpoint has been expressed by Professor Roman Smal-Stocki, and by James Burnham, formerly of the Department of Philosophy of New York University, who in all his writings has stressed the need to eliminate the new Russian Communism.

A further requirement of this in a historical survey is expressed by a Russian in speaking of the failure of the anti-Communist movements during the Civil Wars:

Those who were adverse to the new (Communist) regime could thus be divided into two very different groups; one comprising the property-owning classes (who had been deprived of their all by the Bolsheviks), the officers, the civil servants and all those devoted to the ideals of the Russian State as constituted before the October Revolution; the other, the national separatist groups, which desired complete separation from Russia. It is easy to see that, no matter how antagonistic these two groups might be to Communism, their aims were absolutely dissociated. The unity of the Russian State could only be reestablished in one of two 
ways: either by a restoration of the Monarchy or by federation. Neither alternative appealed to the anti-Bolshevik groups; and this circumstance explains the absence of cooperation in the Civil War which broke out in many parts of the country in 1918. It must be noted also, that the majority of the population, the peasantry, stood entirely aloof from the activities of both groups, and remained during the initial stages of the Civil War absolutely neutral. ${ }^{43}$

With the practical elimination of the monarchist influences, the line is still drawn with the greatest bitterness between the so-called Russian democratic elements who insist upon the unity of Russia and the representatives of the non-Russian peoples, especially the Ukrainians, Baltic, Caucasian and Turkestanian nations. During the first post-war years this latter tendency was little regarded in the American universities and even now is less well represented than it should be; but recent years have seen the publication of several studies such as John Reshetars's Ukrainian Revolution and John A. Armstrong's Ukrainian Nationalism (1939-1943).

The same. division can be seen in the distribution of aid, in the early years, of the work of the East European Fund, Inc., which was created by the Ford Foundation and has done much valuable work. In its later years it has given more money to aid in the preparation and publication of works by Ukrainian, Byelorussian and other scholars and is publishing a series of Ukrainian texts, either original works or books suppressed by the Soviet government. But all of these publishing activities fall far short of the work of the Chekhov Publishing House which has issued over 100 Russian books and received for this, grants (up to 1954) totaling $\$ 1,238,000$. However, on the average, as shown by the Fund's report for 1954, the grants to the several Ukrainian and Byelorussian (Whiteruthenian) scholarly and relief institutions have never been more than a third, at most, of that contributed for similar Russian purposes, in spite of its stated position of refraining from "favoring or supporting any single Russian political grouping." The report shows how the Fund has tended however to see more value in the Russian projects than in the Ukrainian and Byelorussian (Whiteruthenian). ${ }^{.4}$

${ }^{43}$ P. N. Malevsky-Malevich, ed, Russia-USSR (New York, 1933), p. 65. 44 Third Annual Report, 1953-1954, The East European Fund, Inc. (New York, 1954), pp. 48, 86. 
Gradual changes of attitude can also be noted in the American-supported publications of the Institute for the Study of the USSR in Munich, which is intended as a means for assistance to refugee scholars from the USSR, and in the various American radio and other organizations intended to aid in the fight against Communism, such as the American Committee for Liberation from Bolshevism. It is to be noted also in the policy of George Kennan, formerly of the State Department and now connected with the Institute for Advanced Study in Princeton, New Jersey, who is considered an outstanding American authority on the USSR. His entire policy of "containment" has long been based on the same idea of Russian unity as expressed by his uncle, George Kennan (See Chapter III).

To supplement these and similar tendencies in the study of the satellite states menaced by Communism, there has been established in New York another series of organizations to secure American help, to furnish scholarly opportunities for displaced scholars from the countries liberated after World War I and to assist in training new students. This is the Mid-European Studies Center. Its counterparts in Europe are Radio Free Europe and in the university field in the United States, the Mid-European Studies Program at Columbia University. This is more or less on the pattern of the Russian Institute and it is but one example of the efforts that are being made to develop interest in the culture of the satellite states, which, save for the efforts of their compatriots in the United States, have been largely neglected.

A point often raised regarding studies in this area is the limitation placed upon them by the American distrust of Communism which has expressed itself in many Congressional investigations as well as the public and private attempts to root out from the various important fields open or secret Communists or fellow-travellers. This point is raised by Professor James F. Clarke of the University of Indiana: ${ }^{45}$

In more recent times a similar blind emotional reaction to Communism as well as partisan evaluations of the Soviet Union have constituted a threat to the free and rational expansion of East European studies. To-day, college students, teachers, and administrators interested in the area

${ }^{45}$ Area Study Program-The Soviet Union and Eastern Europe, (University of Illinois, 1955), p. 37 . 
dominated by Communism, while they may not yield to anti-Communist hysterics, must at the same time heed its potential effect on parents, taxpayers, legislators, trustees and employers.

It is the opinion of the present writer that such arguments serve merely to cover the failure of the scholars to interpret the complications of the Soviet mode of thought to an American audience. The Aesopian language in which so much of the current Communist propaganda is couched, both for home and foreign consumption, and the belief that truth is what is best at the moment for the Communist Party, have laid a responsibility upon students of Eastern Europe, a burden not borne by the more established subjects where the sources are less subject to deliberate falsification. In addition to this, certain men who followed, during World War II, the tendency to gloss over the cruelties of the Soviet Union on behalf of mutual understanding and a misinterpreted liberalism now find it difficult to disavow some of their most tendentious writings. This by no means im. plies that they are either Communists or fellow-travellers but they deliberately closed their eyes to unpleasant situations, and now shrink from admitting the full truth.

As we have noted above, few, if any, of the outstanding scholars of Slavic have accepted Communist ideas. The burden of Communist infiltration in the past, and in the present, has been in departments and subjects that might be considered most immune to them, especially some of the natural sciences which have only recently become subjects for international intrigue and spying. For this reason, the fears of being labeled a Communist are far less vital than the pressure that has been exerted at many different periods to present Communism as a liberal doctrine that is in harmony with American ideals. It is this misplaced liberalism that has been responsible for what the author of the article quoted calls "anti-Communist hysterics:"

In addition to this, any objective study of the Communistdominated world is rendered impossible, if the supplemental goal is to promote mutual understanding. This of course is an object of study when the system of two distinct peoples is founded upon the same general principles, and when words are used on both sides with similar meanings. In a study of the Communist world, far more can be effected by a rigorous empha- 
sis on the differences than can be gained by soft-pedaling and concealing them.

Another important factor that has worked against the increase of students in the East European field has been the nature of the opportunities which are offered to students. Immediately after the liberation of the Slavic countries, after World War I, there seemed to be a chance that students who acquired some knowledge of Slavic could put it to use in their ordinary vocations. Those opportunities for employment abroad that loomed so large in the calculations of students of Spanish proved to be conspicuously absent in view of Communist actions.

The spurt that occurred after World War II came to an end when the Iron Curtain descended over almost the entire Slavic world, at least so far as the average student was concerned. Men who had received some instruction while in the Armed Services were able to take advantage of the GI Bill of Rights and continue their studies. Yet most very soon found that unless they intended to become real specialists, they would not have the opportunity to use their knowledge.

The colleges and universities needed more men in view of the widespread conviction that Russian, especially, was a proper and necessary subject. Yet the field was relatively limited and did not require many generations of post-graduate students to adequately staff the departments. The chief opportunity besides teaching was government service and this absorbed the greatest number. But, for those who did not care for government work the range of opportunities soon became restricted.

Most of these men and women, who are today specializing actively, are persons who have received fellowships of some kind or value from one or another of the larger foundations (the Rockefeller, Carnegie Corporation and the Ford Foundation). As in other branches of scholarship, and even the sciences, or those humanistic subjects which almost insure teaching positions, these fellowships and scholarships play a more important part in the economic life of the graduate student than ever before and any increase or decrease in them is reflected almost immediately in the number of students. The result has been a steady but perceptible drop in graduate students during the past years. This has not been a bad sign in reality, even though it may superficially seem a lack of interest.

We can be very sure, the world and human nature being 
what it is, that there will be no such reaction against foreign languages as there was during and after World War I. There are already signs that the number of students has dropped to the point where it will remain stationary, or from which it will perhaps rise slightly, during the next years.

The study of Slavic and East European subjects has followed a very definite pattern in the last ten years with its shifts of emphasis reflecting the changes that have taken place in that part of the globe. It has followed political and economic relationships of the United States and we can be confident that it will continue to do so.

Thus, since the beginning of World War I, the picture of Slavic and East European studies in the United States has changed markedly. The prospects today are far brighter than they ever have been. The foundations have been laid and it only remains to build a superstructure to fit into American life and at the same time present a consistent and coherent picture of what that American life, and Slavic studies, really need. The first period of test is over. Now is the time to present Slavic scholarship to the American public and the scholarly world in such a form that it can be assimilated and incorporated in the intellectual life of the nation, and at the same time take account of the possibilities offered by the large section of the population with Slavic traditions. 


\section{THE FUTURE TASKS OF SLAVIC AND EAST EUROPEAN STUDIES}

IT Is obviousLy impossible, under present conditions in America, even to dream of offering any outline for a definite organization of studies of that large area east of Scandinavia, Germany and Italy. We are dealing with several linguistic and cultural entities which historically have been subjected to widely differing influences. Especially in the field of history and of culture in general, the old notion that a boundary could be drawn between the Roman Catholic and Orthodox Churches, or between the Christian and the Islamic Worlds, is definitely antiquated. It was non-existent during the earlier periods of history although it was partially valid for a few centuries. Even at the height of religious separation, the Slavic World was itself divided, the Western Slavs and some Southern Slavs on one side and the Eastern and most Southern Slavs on the other. Today, with the general movements that are sweeping both Europe and Asia, these lines are obliterated.

We are forced, thus, to recognize a far more complicated situation than seemed possible even a few decades ago when the early students of Slavic blindly, though sincerely, followed either the German or the Russian cultural views of the area.

Studies in the United States in these fields must find, despite the many obstacles, a new path, acquire a new breadth of vision, and work out a new outline wherever the old has been shown to be deficient. This can only be done by cooperation among both scholars and institutions. Though the leading colleges and universities have found during the past century their own methods for departmentalizing their courses and faculty, there is hardly one which cannot adapt its resources to contribute to the cornmon cause. We will therefore content ourselves with sketching briefly some of the problems, and their possible solutions, in the field of organization. 


\section{Integration in American Consciousness}

At the present time, educated Americans seem to find it impossible to integrate the concepts that have been forced upon them by events since 1914. The older generation, and too large a part of the younger, view the expanded practical concern for Eastern Europe and Asia as a serious and troublesome addition to the range of knowledge which it is compelled to acquire. This attitude has been fostered by the way in which the expansion has occurred. Under the pressure of World War II, and its accompanying developments, the government and the foundations alike have been spending money to train men in presentday problems and have looked askance at what we may call basic work in the evolution of the situation.

Let us glance at this for a moment. Courses in ancient history, chiefly of Greece and Rome, are an established part of all college and university curricula and are even found in many high schnols. Yet invariably, these courses fail to discuss Greece and Greek culture after the rise of Philip of Macedon and the Roman conquest of Greece. Studies of the Roman Empire rarely extend beyond the reigns of Diocletian and Constantine, where they are lost in vagueness about the Dark Ages and the barbarian migrations. Even in the earlier period, almost no attention has been given to vestiges of Greek and Roman culture outside of Greece, Asia Minor and the Roman possessions in the West.

Thus, there is a cloudy realization that the Code of Roman Law was finally drawn up in Constantinople, but the historical significance of the past is not keenly appreciated. At the same time, anything that can be labeled Byzantine is either treated separately or not considered at all. There is even no realization that the Scandinavian Vikings extended their activities to the East as well as to the West and such striking evidence of this as the marriage of the daughter of Harold the Saxon, the last Saxon King of England, to Volodymyr Monomakh of Kiev, seems an incredible and isolated event. The scholars at Dumbarton Oaks and the Mediaeval Academy of America are indeed doing work on Byzantine history, culture and institutions but the other scholars working on the foundations and development of the modern Western World have not attempted to take their work into account, and are still limiting the modern Western World to the British Isles, France, Germany, the Holy Roman Empire and 
its descendants, ignoring the contacts of that world with Byzantium in the early and later Middle Ages.

With a similar lack of understanding, the average student, though aware of the fight between the Holy Roman Emperors and the Popes, rarely knows that the Empire was then pushing into Slavic territory or that Saints Cyril and Methodius, the Apostles to the Slavs, were in Rome as well as Constantinople.

There is a scattered appreciation of such events as the Latin seizure, and the Turkish capture, of Constantinople but only for their impact upon the life of the West. The arrival in Western Europe of scholars from Constantinople is taught as a great influence in the Renaissance but no attention is paid to their origin or where they had studied.

The situation is even worse for later periods. There has been an almost complete neglect not only of the history of the Balkan Slavs but of the Greeks as well. For years after the establishment of the Gennadeion in Athens, one of the few still unplundered collections of Greek and Slavic manuscripts, Slavic scholars were as unaware of the existence of this collection as the classical scholars were unaware of its importance.

One result of this traditional lack of understanding of early Eastern history has been the tendency of American scholars to accept without hesitation either the German view of Eastern Europe as a relatively primitive region, or the Russian view that in some way everything in the East was Russian and that it was only natural that Catherine II of Russia should dream of becoming the Empress of the Byzantine Empire with her capital still at St. Petersburg.

Thus all the peoples of Eastern Europe disappear from European history shortly after the time of Constantine and do not reappear until the foundation of St. Petersburg and the development of the Eastern Question in the late eighteenth century. Even the national struggles in Vienna during the reign of Francis Joseph II are not evaluated, and far too many would-be-students of Eastern Europe are still under the impression that movements for national independence during World War I and the Russian Revolution arose out of thin air.

The complicated events of the last decades pre-empt the concentration of students and give them little time to grasp the background which underlay the past and gave rise to the complexities of the present. 
It would be presumptuous to expect adequate and detailed knowledge of Eastern history to be added to the intellectual burden of all students, even though it would be desirable. The most that can be hoped is that students and scholars interested in this field will be able eventually to focus more attention, in the general curricula, on a few of the major trends that worked openly and secretly in Eastern history for over a thousand years, culminating in the present situation.

The last years have seen a few attempts, like those of the late Dr. Bilmanis, Minister of Latvia in Washington, to prepare a history of Latvia. We now have histories of Lithuania, Poland, Czechoslovakia and two or three of Ukraine. But there is still lacking a general survey presenting in readable, popular and general form the outstanding developments in the Slavic area. The development of such a synthesis of the East European culture, in a form that could be included with the more detailed studies of the Western countries, would go far in overcoming the vague and unrealistic ideas which are fostered either by ignorance or by the propagandistic works of the formerly dominating nations.

When we remember that it was nearly the end of the seventeenth century before Eastern Europe acquired the form that it had on the eve of World War I and that this order was seriously challenged throughout the nineteenth century, we can see the necessity of a complete revision of many of the established and traditional concepts. Such a need must be recognized by the educational leaders as a whole, for Eastern Europe has greatly and consistently influenced the West. No greater step forward can be taken than to emphasize this historical fact and to show the important role of Eastern Europe, both positively and negatively, in shaping the world as we knew it at the beginning of the twentieth century.

\section{The Divisions of the Area}

Awakening the American intellectual world to the need for reassessing its concept of Eastern Europe is, of course, an essential problem for Slavic students, but it can be fully accomplished only in cooperation with those individuals and institutions concerned with the general outline of human history. Far more than a mere multiplication of courses, of lectures and of journals is needed. Yet if we assume that steps are being taken toward this end, there still remains the very pertinent question of what 
divisions and sub-divisions of the area are to be used in any detailed study. It is at this moment that we come face to face with the tremendous historical and linguistic complications.

First considering linguistics, Slavic easily can be placed at the center, for the greater number of the inhabitants of Eastern Europe speak one of the Slavic tongues. The traditional point of view, which is now being challenged by linguists, is to divide the Slavs into Western (Czech, Slovak, Polish and Lusatian), Southern (Serb, Croatian, Slovene and Bulgarian) and Eastern (Great Russian, Ukrainian and Byelorussian), and to emphasize common linguistic aspects.

This is of advantage from the strictly philological point of view; it is less valid when considering culture and history and the influence exerted throughout the last millenium by the neighboring states and cultures. As has been noted already, the constantly shifting line between Eastern and Western churches cuts directly across the Slavic world. On one side are the Czechs, Slovaks, Poles and Croatians, all of whom have been primarily under Western influence. On the other are the rest of the southern and eastern Slavs who have drawn their original inspiration from Byzantium and have then undergone, in varying degrees, cultural influence from the Latin and Germanic west, the Scandinavian north, the Mongol and Tatar east and the Turkish south. Ukraine, and to a lesser degree Byelorussia (Whiteruthenia), have felt a consistently strong Western influence throughout their history. Western influence among the Serbs has been more spasmodic, while Russia (Moscow) remained relatively free from such influences almost until the time of Peter $\mathbf{I}$.

Furthermore, the area also includes the Uralic-Altaic peoples, the Finns, Estonians, Hungarians, Turks and many less developed peoples. These can hardly all be treated as offshoots of Slavic. The Uralic peoples, especially those who are most highly developed, have shared the influences of the Slavs, and have been closely connected with Western Europe. The Finns and Estonians have had strong Scandinavian contacts and the Hungarians have been closely associated with the Empire, the Poles and the Czechs. The Altaic peoples, largely Mohammedan, have become an inherent part of Islamic culture and yet, despite their distinct linguistic and cultural heritage, their fate has been closely linked with that of the Slavs. In addition, there are the modem Greeks, direct heirs of the Byzantine tradition with their 
own sharply defined culture; the Romanians, who are proud of their Latin traditions; and the Albanians, who form a distinct Indo-European linguistic group crowded between the Southern Slavs and the Greeks. Neither can there be excluded such peoples of the Caucasus as the Georgians, the Armenians and the Azerbaijanians, nor other Christian and Mohammedan peoples formerly included in the Russian Empire.

The time is long past when all of these national groups can be studied only in terms of the Russian and Ottoman Empires. Their history and their struggles for liberation create many cultural subsections which cut across linguistic boundaries and, in part, natural geographical subdivisions. It is difficult to name satisfactorily these cultural subsections, for they vary in the different periods of history. Yet, the definition of courses of detailed study or area programs, which have become so popular at the present time, demands it.

There is another difficulty which arises. The events of World War II and the creeping Soviet imperialism have succeeded im dominating all of the states which were established, or attempted after World War I. In the western extension of the Iron Curtain, only Finland.in the north and Greece and Turkey in the south have succeeded in maintaining a precarious independence. As a result, all of the programs of instruction that have been arbitrarily set up exclude these three countries. Whatever value such a division may have at present, it is certainly no guide to the past, for at times Finland was under Swedish rule, which extended south of the Gulf of Finland. Likewise, for centuries Greece, the Southern Slavs and Romania (then divided between Wallachia, Moldavia and Transylvania), together with Ukraine, formed another definite cultural block, which to a large degree shared the same political fate.

For many years, the nations of the Balkan Peninsula were treated as a Balkan block and, because of the ways these states secured their political independence, they shared years of stormy political life. The term "Balkans" was then, with considerable contempt, applied to Greece, Bulgaria, Serbia, Montenegro, Albania and Romania. Yet after World War I, when the Adriatic littoral was added to Serbia and Montenegro to form Yugoslavia and Romania recovered Transylvania and Bessarabia, the name came to have little meaning. Now with Turkey playing a positive role, efforts have been made to use the name South- 
eastern Europe, but with little success. "Danubian Europe" is worse, for the Danube crosses both Austria and Hungary, and avoids Greece and Albania.

At the present time, the term "Eastern Europe" is probably the least objectionable but it is ridiculous to apply this term to Czechoslovakia and Hungary which are almost in the heart of Europe. Still, this is the term, added to Slavic or Slavonic, used as a general title by both the British Slavonic and East European Review and The American Slavic and East European Review. But the culture area also includes all of the former Russian possessions in Asia, for the Urals owe their position as the boundary of Europe more to the fact that they run roughly north and south at the easterm end of the Caspian Sea, and so are useful to cartographers, than to any historical importance.

The term "Mid-Europe" has been introduced lately to cover the history of that strip of countries which won their independence after World War I and lost it after World War II. It is an attempt to unify the non-unifiable, except in terms of their present fate, for during much of the last thousand years the fate of Czechoslovakia, Poland and Hungary has been intertwined, but Poland has been involved with Lithuania, Byelorussia (White Ruthenia), and Ukraine, while the main relations of Latvia and Estonia have been with the Scandinavian and other Baltic peoples.

For purposes of detailed study then, a division can be made between the eastern Baltic shore in the north, Poland, Czechoslovakia and Hungary in the center, and the states of the Balkan Peninsula, including Turkey, in the south.

What then can we do with Ukraine and Byelorussia, two of the three East Slavic states? For both countries connections with Moscow have been of a special character with a long record of turbulence, opposition and attempts at independence. They have lived their own lives with intermittent contact with the West; in fact, it was through them that most of the purely Western influences drifted into Moscow and the land of the Great Russians, which in ancient times was more closely connected through the Volga River with the Caucasian group of peoples and the Golden Horde.

Attempts to divide the entire area into regional sections with common problems and cultural development produces only confusion, for such divisions are applicable only to short periods in 
the ever-changing kaleidoscope of history. The realization of this fact presents one of the greatest obstacles to the student of present problems. The idea, fostered in Prague, that the key to all East European problems could be the assumption of a single Slavic history and Slavic culture can be easily proved to be as vain as Pan-Germanism, Pan-Turanianism, and Pan-Asianism.

Yet, today this over-simplification has been twisted by the Russian Messianic concept into a formidable weapon against the rest of the world. The Communist theories, like the old Tsarist theories of Moscow as the Third Rome, cannot be laughed away. They must be met by accurate and careful study and this does necessitate some sort of recognizable division. But, the solution to these contradictions cannot be found in either the Russian or the old Germanic theories; it demands the most serious consideration from the modern scholars of the entire world outside the Iron Curtain.

\section{Undergraduate Courses}

Considering the material that can be reasonably included in the curriculum of the average American college, we must severely limit our expectations. Because the average college aims to give a well rounded education in many fields of knowledge, the number of persons specializing in Slavic and East European subjects will be very limited. The amount of time that the average student can spend on these subjects and the amount of effort that the average institution will expend to make them effective, is limited. Furthermore, there will be few colleges, not connected with universities, either inclined to embark upon an ambitious program, or supplied with the resources to undertake it. But, this does not mean that nothing is to be done or that it is to be done carelessly.

Until that time when the main facts of the history of Eastern Europe and of Eastern European and Slavic culture are included in the general scheme of the development of the modern world or in courses in the development of contemporary civilization, interested persons on the faculty must work out a minimum program. This will vary according to the general content, either in history or literature, and will fall into its proper place in the general curriculum, whether or not a special department is established. There are some things that can be expected and we will divide these into four headings: history, literature, culture and language. We will here consider the first three. 
The prime requirement in all these subjects is scientific accuracy, something which is far too often honored in the breach. There has been in the past too great a tendency to accept some superficial treatment composed of half truths. We must remember that ignorance, and conscious ignorance at that, is often better than incorrect knowledge. The problem lies not so much in what a person does not know as in what he knows wrong.

At the present time, there scarcely can be given a course in modern history which overlooks and omits the questions that have been forced upon the attention of the world by Russian Communism. There is, therefore, little or no reason why the main facts of the present situation should not be correctly given with proper weight laid on the Soviet structure and methods. This involves a clear recognition that there are important differences not only between the old capitalistic and the new communistic Russia, but also that there is an ostensible stress which the Soviet Union lays upon the differences between the populations inhabiting her republics, subject as they all are to the same Russianization. There can be no excuse for the oft repeated view that all the people of the Soviet Union are Russians in the old sense of the word. There is no reason for the arbitrary omission of the nationality problem on the ground that it has no validity in fact or experience just because it was denied by the Tsars a century ago. There have been too many instances of even responsible publications omitting from accurate surveys references to such problems, at the will of certain anti-Communist nationalist Russian groups. Although there is available today adequate and easily accessible literature, far too little of it has penetrated the scholarly world which is still burdened with the traditions of the past.

The same can be said of literature. For many years masterpieces of Turgenev, Tolstoy, Dostoyevsky and Gorky have been included in courses on modern European literature. Still, far too often, they have been presented in a vacuum, without any attempt to equate them with Russian life and thought. This is perhaps less common today, but immediately after World War I, it is not extreme to say, there was a Western science of Russian literature almost as far from reality as that first French translation of Anna Karenina which, in the interest of clarity, calmly omitted the entire Levin-Kitty story.

On the other hand, with the number of available translations 
of nearly all the prominent Russian authors of the nineteenth and twentieth centuries, there is no reason why courses on Russian literature in translation should not be offered. The material can be easily gathered to give an adequate picture of the development of the literature for the non-specialist. Whether this is done as part of a general course, or as a special course, will depend upon the program of the institution but it will benefit not only the general student but also the person who is endeavoring to learn the language.

The problem is more complicated for the other East European languages. Perhaps Polish literature is the only one that has been translated with even near minimal adequacy. Still, there are a number of translations from the Czech, especially from Karel Capek, the popular dramatist who was active before World War II. There are some good Ukrainian translations, especially of poetry done by the late Percival Cundy and the selections already in English give a fair representation of all the major Ukrainian authors. The literatures of the other Slavic groups are still poorly represented in translations.

There is a real need therefore for the preparation of a series of anthologies in translation, not only from the Slavic languages, but also from the other literatures of East Europe. There may be difficulties in securing publication of such works, and hesitation in introducing them with success into the various courses, but there is no reason why any college library should not work to build a collection of such works, even if it is not interested in expanding its study in this field.

Where there are courses in one or more of the languages of the area, it will be, of course, easy to prepare courses on the literature with readings in the original. Yet, these can never replace the full need for courses in translation or courses in which the originals are supplemented by translations.

The same applies to courses in the fine arts, especially music and painting, both of which have flourished in Slavic lands. There are special difficulties here that are not present in the literature, for in the past, and especially the nineteenth century, most of the Slavic artists appeared in the Western World as either Russian, Austrian or Italian. As such, their contributions have been hidden even beyond their own desires, for in 1918 the world discovered that many artists, who had been invited as representatives of the dominating empires, rebelled and proudly declared 
themselves Poles or Czechs, much to the surprise of their audiences.

We can be sadly confident that it will be some time before undergraduate courses in East European history and culture will everywhere acquire a proper direction and clear acceptance. But year by year, as these studies expand in the colleges, an increasing number of students are affected and Slavic studies are coming closer and closer to the academic level and seriousness of the older disciplines. This offers hope for the future and, while we cannot expect a Slavic department to become one of the numerically larger departments, it can rise to its opportunities and exercise its functions both in training specialists and in broadening the knowledge of a larger and larger number of students. The lag in Slavic studies is diminishing with each year and it will soon vanish entirely if developments of the present day are carefully regarded.

\section{Language Instruction}

The first task of a Slavic or East European language department is of course to teach the language. It should be taken for granted that any person who claims to be a specialist in the history and culture of any country should be able to read, write, speak and understand its language. The language courses in any department are intended to satisfy these requirements. This however is a goal and the merest contact with even good students will show how far it is from being fully realized. Yet it must be the goal even though we accept something far short of it as that which can be reasonably attained.

There is no easy way to learn a foreign language and to maintain fluency in it. And fluency can be best secured by a constant use of the language, hardly possible in the United States despite the aspiration of the student. Somewhere, somehow there must be a compromise.

There are, of course, scattered individuals like the late Professor John Dyneley Prince, who seemed to have a special gift for speaking foreign tongues. As a matter of fact, Prince built his entire scholarly and political career on this inborn gift. His knowledge of spoken tongues was fantastic, but it should be recognized that he maintained it only by a constant preoccupation with language. The time that others spent on bridge and other hobbies, he dedicated to reading dictionaries and annotating grammars. He continued, so long as his health allowed, 
the labor which made it possible for him to perform his almost incredible feats. Men like Prince are exceptional, but they emphasize the fact that there is no single road to success. Every individual learns languages in his own way and hence there can easily be a wide divergence of educational methods recommended.

There was a time when instruction in modern languages followed the methods used in studying Greek and Latin, with an excessive emphasis on knowledge of grammar and a corresponding neglect both of the finer points of usage and the ability to read fluently. The old joke that the object of learning the classical languages was to be able to distinguish the different uses of the genitive case was true only when scholars ceased using Latin as a medium of communication. While this was a passing phase, it left its mark on the study of modern languages. The Slavic languages, from their inception as subjects of university study, have been subject to this temptation. But even before the application of so-called modern methods, there was a larger proportion of serious students able to express themselves satisfactorily in the Slavic languages than there was in the more common tongues, such as French and German.

On the other hand, the great increase of interest in Slavic languages came during World War II and this left its imprint on the methods of instruction. For military and governmental purposes, speaking knowledge was very important and became even more so when the schools were charged with training men for intelligence work. The emphasis on a speaking knowledge of Slavic languages was important in World War II because the number of young Americans who knew these languages well was seriously declining. Thirty years before, there were many young Slavs who had but recently migrated to the United States or were the children of parents who spoke their native languages fluently though grammatically incorrectly. The children of these people, trained in American schools, have lost most of their facility in their fathers' tongues and need fundamental training.

At the same time the slow but persistent strengthening of the Iron Curtain and the refusal of the Soviet government to allow free emigration of its citizens has reduced the number of young instructors available. The majority of competent instructors in America have lived in this country since the close of World War 
I and many of them are unfamiliar with the latest turns of the language as used in the Soviet Union.

The difficulty of obtaining instructors is counterbalanced by the great improvement in methods of recording and reproducing sounds. It is now possible in almost all institutions to give students accurate and well rendered records and tapes of the leading Russian dramas and speeches as recorded and broadcast by the Soviet authorities themselves. It is also possible for the students to record their own pronunciation and compare it with the accepted standards. The use of these modern scientific and technical aids is undoubtedly improving pronunciation, though it is by no means certain that it is equally satisfactory in teaching fluency when the student is called upon to express his own thoughts.

At the same time, the new interest in language often overlooks the fact that students may desire to learn a Slavic language for widely differing purposes. In this respect he does not differ from the average English speaking person who may fully master the language and still be almost completely ignorant of the technical terms (jargon) of some particular profession or activity. Disregarding the notion that a foreign language should be learned only to read belles-lettres, we far too often replace it with the ability to carry on ordinary conversations on general subjects. There is of course, in all languages, an irreducible minimum of words of universal applicability, but methods must be found to include special vocabularies for students with special interests. This has been met in part by the production of technical dictionaries for the several sciences but much work remains to be done.

These remarks apply to all the languages of East Europe. However, modern methods have received their fullest application in teaching Russian, although auspicious beginnings have been made for others, especially Polish. It is highly desirable that textbooks and other aids be increased in the near future to provide all Slavic languages with adequate materials, adapted to the use of English-speaking students. Russian is still the language in which most American students are interested. In a way this is natural because Russian, both by its political importance, the number of persons speaking it and the reputation of some Russian writers, is undoubtedly the most important. Other Slavic and East European tongues are adequately taught 
only in some of the larger universities or in smaller institutions with special interests, be it circumstances of the administration or the character of the student body. Yet it is hardly true that any person interested in the broader studies of Eastern Europe can be adequately equipped if he possesses only a knowledge of Russian, though this does not make the situation as hopeless as it might seem.

There are so many common roots and forms of expression in all Slavic languages that it is possible to prepare a course which will emphasize the salient features of each language, equip the student with a knowledge of any one Slavic language, and still enable him to handle, for scientific purposes, the others without too much difficulty. This was successfully done by Professor Prince at Columbia when, with a fine disregard for special grammatical features of the different languages, he arranged a general reading course in the Slavic tongues. For some years, Professor Manning followed his example. The course was finally dropped because of other departmental needs but there is no reason why such a course could not be standardized and made available in many institutions which are unable to afford a complete university staff to teach the different languages individually.

The greatest obstacle to the study of Slavic languages is the fact that, until very recently, few students reached the graduate level with an adequate background in the languages. This has been somewhat relieved by the introduction of Russian and other Slavic languages in the colleges, but often language instruction could be advantageously introduced in high schools. Furthermore, there are many institutions, largely supported by churches or societies, which give instruction for which colleges should be willing to give appropriate credit.

Such credit could be granted by a rigid insistence upon accomplishment coupled with a liberal reading of the requirements for college entrance. Thus, despite the lesser emphasis paid to definite entrance examinations, it should be possible for educational institutions and state organizations to arrange examinations in East European languages even where they were not learned in a recognized school. In many instances the efficiency of summer courses, such as those given by the Ukrainian $\mathrm{Na}$ tional Association under the supervision of the Ukrainian Free University, could be checked by some central body. If instruction were satisfactory, credits could be accepted in toto, or the 
graduates could be given the opportunity of an individual examination in order to receive credit. It would seem that almost all major churches and societies in the United States interested in the study of a foreign language would react favorably if there were any assurance that students in their courses would receive proper recognition.

The American educational system is neglecting, at present, those resources for study of East European and Slavic languages which already exist. While it is true that formerly instruction was often given by ill-prepared and incompetent teachers, the arrival in this country of large numbers of educated DP's, often with teaching experience in their own lands, has changed the situation, and made it possible to build up a large cadre of language students, prepared to undertake more advanced work at an earlier stage.

In the language field as nowhere else, we can clearly see marked improvement in the past thirty years. There are better textbooks and better instructors. If there is a negative aspect, it is in an excessive emphasis on what is conceived to be a modern system of study, which rests too much upon adherence to hypothetical rules regarding how a language should be learned, and a tendency to look askance at any exceptions to this, regardless of what results may have been attained. There is still much more to be done before the knowledge of these languages is sufficiently spread throughout the intellectual and research organs of the country.

\section{Graduate Work}

Considering the problems of graduate study in American universities, we must not overlook the fact that Slavic studies in Europe developed entirely under the methods and system of German scholarship. Although this may seem surprising, it was at Vienna, Leipzig, and Berlin that the outlines of the modern sciences were laid. The early universities at St. Petersburg and Moscow were largely staffed by Germans and the oldest university in Slavic lands, the Charles University of Prague, lost its Czech character during the Thirty Years War. A Czech section of the university was begun as an adjunct only in the 1880's and did not recover its original insignia until after the liberation of Czechoslovakia. Hence, the German system of scholarship was considered basic, even though it was greatly altered by later development of Slavic studies at the universities of 
Prague and Krakow. The influence of Prague and Krakow was natural, for it was in Slavic universities in Slavic lands that Slavic would become the cornerstone of humanistic teaching, acquiring a position similar to that of English and American literature and history in American institutions. We can never hope to equal or surpass the work in these institutions though we can admit it without any sense of failure.

Since American graduate schools have been based on German models, they inherited the German division of faculty with history and its allied subjects separated from literature and philology. Nor have these divisions been changed noticeably by grouping various chairs in allied subjects into departments. While there have been attempts, as at Harvard, to bring together in the Slavic pattern, all courses dealing with Slavic subjects, this practice has not been generally followed. The result is that history and literature have been taught separately and have been combined only in part in more recent Russian and Slavic institutes.

In both general fields, the usual methods and regulations can be applied easily and completely; hence, the introduction of Slavic and East European into the general curriculum has not caused difficulties. There remains only this question: should there be some provision for normally including one or more general courses from either section in the curriculum of the other to augment the background of those students tempted to specialize too closely, who might thus fail to see the general cultural problems which any literature or history presents.

There are, however, certain limitations which the student will encounter, due largely at the present time to the rule in the free world which prohibits a free exchange of students between countries. A student desiring to work in English, French and German history can go freely to the appropriate intellectual center to consult sources; a relatively large number of students in these fields have studied at the universities and archives of the country in which they were interested. This was also true to a certain degree, between the wars, in the so-called succession states when every year students went to the universities of Poland, Czechoslovakia, Yugoslavia and Bulgaria, the Baltic and Greece. Today this is impossible and the administration of students' programs must take this fact into account. The limitation severely restricts research in certain slightly explored areas such as the remains 
of Slavic literature from the Middle Ages, the unpublished memoirs and manuscripts of many modern writers, and memorabilia from many periods of historical and economic importance.

These limitations can be partly overcome by increased research in the archives of many of the countries still free. There is doubtless much material in the libraries of Western Europe, the Scandinavian countries, Greece and Turkey which has never been adequately studied by a Slavic expert.

Limitations exist to an even greater degree in archaeology and ethnology, since research before World War I was still in its infancy and subsequent discoveries have been filtered through the exigencies of Russian Communist propaganda. This imposes upon the student the necessity for a most thorough and careful analysis of all Soviet references and newly published material, often edited to suit the policy of the moment, for it often involves a direct contradiction to what the Soviets declared to be true in the period between the two World Wars. This is the situation not only in history, but also in the literature of the past and present. The theses issued by the Communist Party for the three hundredth anniversary of the Treaty of Pereyaslav (1654-1954), after the death of Stalin and under the "new" Soviet policy, stand in sharp contrast to the published statements of Soviet scholarship during the 1920's and 1930's. Similarly, the rewriting of the biographies, during the relatively unhampered conditions of the early 1920's, of such authors as Dostoyevsky, Shevchenko, Franko, Mickiewicz and many others, makes it impossible to accept uncritically either the older Soviet accounts or even much of the material published under the Tsarist regime.

There is then imposed upon faculty and students, the need to recognize that Slavic studies cannot merely accept the latest discoveries and statements as a correction of the past, as in other fields, but must include the most careful consideration of whether in the present or the past they have been more grossly falsified. Reportedly new discoveries in the humanistic and cultural fields may be only a dialectic exercise of the organs of the Tsarist or Communist regimes in order to deceive the outside world. For example, the declaration of the validity of "socialist realism" meant a deliberate misinterpretation of the writings of earlier Communist authors, which can be understood only in terms of politics, not literature. Promulgated ideas were accepted only after the publication of the official list of writings as decided 
by Communist authorities. Similarly, the original philological theories of Marr soon lost what validity they possessed when they were adopted by Marr's fellow-Georgian, Stalin, as the Soviet system and were imposed for twenty-five years to serve Communist purposes. Even what remained valid suffered when Marr, after his death, was officially discredited and his original ideas went through a second period of wilful perversion. Such instances could be multiplied by the hundreds, even including Sosyura's poem Love Ukraine, which was deemed worthy of a Stalin Prize only to be condemned, a few years later, as antiCommunist and "bourgeois nationalist."

This constant shifting of Soviet truth has involved strange deviations by even distinguished scholars who have tried to combine their sense of scholarship and accuracy with their desire to be admitted to the Soviet Union for further study. It has also increased the American public fear of Communism and has aided the rise of the so-called "anti-Communist hysteria" which has restrained men who, though not Communist themselves, are unwilling to be accused by the Soviets of open hostility.

There is still another unsatisfied need in Slavic studies. The Western World, since the seventeenth century, for good or ill, has relegated religion, or the lack of it, to a subordinate place in modern history. While recognition is given both religious and non-religious authors and movements, nowhere have religious motives played the ultimate primary role. The contrary is true in the East European area, where religion, or opposition to it, plays the same role it did in medieval Europe. In Russian literature of the nineteenth century both Leo Tolstoy and Dostoyevsky were absorbed in the world of the Orthodox Church and, in their reaction to it, were leaders of the westernizing intelligentsia. Neither's influence can be understood without a consideration of the ethos of Russian Orthodoxy, but this is rarely treated as a serious subject, even though it furnishes the key to that Russian Messianistic dream which so frequently emerges in the stream of Russian culture. In a lesser degree, the same can be said of the more negative Messianism of Mickiewicz and other Polish writers, of the goals of Shevchenko and, above all, of the patriotic works of the Serb poet, Nyegosh. In addition, there is the almost completely unknown world of the Russian Old Believers, or Starovyery, who have left an imprint on many fields of Russian culture. Although rarely mentioned, they are far better 
known in the Russian revolutionary movement, particularly for their preservation of old Russian icons.

Still another field for which material is available, is the history of the Slavs and Slavic culture in the Western World. Professor Jaroslav Rudnyckyj of the University of Manitoba has detailed changes of the Ukrainian language in Canada, and H. L. Mencken has provided startling information on Slavic languages in America, in his The American Language, but the full extent of these changes and the effect of American life on Slavic folklore and folk art, as well as the history of the settlements, has not yet been fully studied. At present, because of support given by foundations and the government, stress is laid upon present Slavic conditions and culture. This is only natural, but the present, and indeed the future, can only be understood by the past. There is much historical study to be done with the resources that the United States and Western Europe can furnish. Slavic history has been so consistently neglected, or studied in such narrow contexts; that its general lines of contact with the West and Asia have not yet been established with any degree of certainty, even in the Slavic countries. If interest has been shown in the relations between Kiev and the Scandinavians, it has not been extended to the contacts with Byzantium during all ages. Nor have scholars examined the Swedish-Polish relations from the viewpoint of both countries. The interplay of the Balkan Slavs with both Italy and the Ottomans is still veiled in darkness.

All these subjects can be studied by Slavic scholars in America without limiting the study to an assumed narrow sphere which has, too often, been the fate of studies both in Europe and the Slavic lands. The viewpoint of American students, therefore, with a broader perspective may result in a new school of Slavic studies, oriented by an impartial attitude to either the Russian imperialistic claims or the German desire to treat Eastern Europe, in the broader sense, as a subordinate arena in the world's history. These traditional viewpoints are today being outmoded rapidly by current history; therefore, the sooner American Slavic and East. European scholarship realizes its own possibilities and its subject matter, the more valuable will be its contribution to the welfare of the United States and the world.

\section{Area Studies}

The development of area studies, which first attracted wide 
attention during World War II, fills a certain gap in the general organization of Slavic and East European studies. They compensate for a deficiency in the education and application of students but they can never fully replace the work of the graduate school. Area studies are at their best when they train young men and women in a knowledge of regions relatively unknown to the general public, which for one reason or another are so inaccessible that few, if any, of the students will have an opportunity to visit them in the course of their studies. They can then be regarded in two quite different ways, for they are either a desirable prelude to more serious work or they are vocational schools of the highest class. In either respect, they will prove their value if properly handled.

To understand the place of area studies, it must be recognized that the American university system has sharply differentiated between the cultural linguistic phases and historical and economic aspects of any given section of the world. Both areas of understanding require a knowledge of the general geography, the outstanding products of the region, its population and characteristics. It has been far too easy, in the past, for students of Slavic, as well as other cultures, to secure a knowledge of the literature of a period without an adequate realization of the background against which that literature was produced. To cite an example from Russian literature, during the first half of the nineteenth century, very few Russian writers ever visited Kiev and apart from the visit of Pushkin to the south of Russia and the service of Lermontov and Leo Tolstoy in the Caucasus, there are few works which picture anything but St. Petersburg, Moscow and a small area south of Moscow. While the average student does not expect such a limitation of subject matter, it is at once obvious from the most superficial knowledge of the expanse of Russia. We could parallel this case with any number of others.

From this point of view, area studies represent but a slight increase of detailed knowledge over that which the average student acquires before he begins specialization in any linguistic or historical field. This knowledge must be supplemented by detailed studies in one of the accepted fields of learning if the student is not to remain a talented amateur.

But there is another aspect of area studies which has given them their vogue at the present time. The global complexion 
of World War II brought home to the American government, all far-sighted educators and even to members of the general public, the tremendous ignorance which existed in the United States concerning all parts of the world except some sections of Western Europe. It was urgently necessary to prepare, in the minimum time, relatively large numbers of individuals to serve throughout the world. The involvement of the Soviet Union and the Nazi overrunning of the states to its west further emphasized this need. Area studies were the result.

These studies were definitely geared to educate men and women who could be quickly called in case of need. That need still exists and undoubtedly a large percentage of the students who enter such concentrated programs hope to put their knowledge to practical use, for the most part, outside the universities. There is still a great demand for area courses and if ever the Iron Curtain were lifted and free commercial relations re-established, we would speedily find that even with all these courses, the demand would outstrip the supply.

But, it seems likely that area studies will diminish in popularity if Slavic and other East European studies find their rightful place in the undergraduate curriculum and provide students with a real appreciation of the significance and general culture of the area. If that were so, they might continue with still greater detail, for an area study including the entire Soviet Union and the satellites becomes almost a contradiction in terms. It would be the same as if a student selected North and South America for a single area study. It becomes very little more than a brief survey of conditions in some particular field. This danger has appeared already in places where area studies have been given on the Slavic lands and have tended to become mere adjuncts of certain phases of Russian and Communist politics and thought.

Taken in the true sense, these courses have amply fulfilled the purpose for which they were intended. They have served to focus attention on many neglected problems. More than this, they have served to round out the point of view of many students, but their unfortunate preoccupation with the present has also created lacunae which can only be filled by other means. Area studies, in their present sense and scope, are a welcome sign of progress but they are not an adequately developed source of our knowledge of Slavic and East European subjects. They are a step in the right direction, have contributed much to 
overcome the almost complete ignorance with which our country entered World War II, but they fall short of the full needs.

\section{Summary}

We have now reviewed the history of Slavic studies in the United States indicating their scope, their limitations and their prospects. It remains to summarize all this and, in terms of past experiences, to make some tentative predictions of needs for the future.

The number of students of Slavic and East European subjects increased many times during and after World War II, because public attention was centered on this area. There are now signs which indicate that this marked increase is coming to an end. For propaganda purposes, sometimes deliberate and sometimes based upon ignorance, slackening interest is attributed to the fear of being labeled a Communist. Yet there are deeper reasons, for it is rare that the rush of American students into any subject, whether a science or a humanistic study, lasts more than a few years. One reason is, in many cases, purely materialistic. The overwhelming majority of students who pursue higher studies do so for purely professional reasons, either in government service, scholarship, journalism or business. An added complication today is the fact that most students expect to receive scholarships or fellowships during their period of study, and these have been distributed liberally by the Foundations, colleges and universities. Yet, at the very moment when the number of students in Slavic studies show signs of diminishing, we are also given an intensive barrage of propaganda on the need for increasing the number of students in the natural sciences. There will be increased future assistance for the sciences resulting in more available and far better positions than in the Slavic and East European field.

We must remember, too, that because of the rapid development, most of the key men in Slavic studies, no matter what their fields, are still relatively young. Few are over fifty-five and, unless the mortality rate experienced during World War II is repeated, we can only accept the fact that the rate of promotion will be slow and attrition by retirement and death will be at a low level. Prospects for advancement, then, are not as good as they were even ten years ago although there will always be openings for the well trained scholars.

A need will probably last longest in Eastern non-Russian 
languages for, with the passing of time, the present lack of competent scholars in many of these countries will be felt more and more. There will also be a lack of those who have really studied the origins of the present situation, the past history of these lands and even of the Russian people and are familiar with those currents which have led to the development of the present situation. We need, in other words, to study the Byzantine relationships with the Slavs, the pre-eighteenth century German contacts with the Slavs, the nineteenth century, and those more specialized subjects such as archaeology, and ethnology, which are still ignored.

The second aspect closely connected to this, both in the present and future, is the furnishing of an instructional staff. In some fields there are still too few men now available and while the younger generation is being trained, the United States is wasting the services of many competent scholars who have arrived since World War II began, who, because of their ignorance of English, are often compelled to take menial and unintellectual positions. This is a tragic waste at a time when so much half-knowledge is being disseminated. There must be more contact between these newly arrived specialists and the general educational system. Some of these men undoubtedly need special training to equip them to function advantageously in the American system, but it is sheer folly for the country and the universities alike to discount them wholly, or to confine them to minor institutions maintained by their own groups. American scholarly societies should make every effort to bring into their membership the newly arrived scholars and to cooperate with those institutions which have been recently transplanted to America, such as the Shevchenko Scientific Society. By neglecting to do so, American education is overlooking a large reservoir of trained personnel with long experience and a wide range of knowledge and ideas.

Another pressing problem is the need for money, money for the payment of faculties, for scholarships, for the expansion and establishment of libraries and museums. The lack of financial resources in the past has often been the greatest handicap, for before World War II contributions for this type of work were few. While the Foundations have contributed handsomely to make the present expansion possible, it is hardly to be expected that they will continue indefinitely. Thus, even now the East Euro- 
pean Fund of the Ford Foundation seems to be in the process of liquidation.

Similarly, with the pressure exerted on universities, we can scarcely hope that they, already pressed for funds to conduct research in other branches, will be able to provide the money needed for Slavic and East European studies. At the present time, there is a movement on foot to secure large grants, on a one-time or yearly basis, from many of the larger corporations. The plans offer encouragement but there is always the danger that funds will be diverted to those subjects which promise the most direct advantage to the donors, and while this may set free certain university funds, it may also serve to furnish those favored departments something more than their regular share of the institutional income.

On the other hand, many societies of the larger groups of Slavic and East European peoples possess relatively large sums of money which can be used for cultural purposes. Some of these societies have already awakened to their responsibility and are doing praiseworthy work in publishing materials in English, in supporting refugee scholars and in maintaining cultural institutions. It can only be hoped that all of the societies will consider carefully the opportunities that are offered for aiding in the development of endowment funds and gifts for Slavic and other study.

In connection with this, the universities have an obligation to keep an open mind about these offers and not to judge them in terms of the teaching accepted in Hohenzollern Germany, Hapsburg Austria-Hungary, Romanov Russia and the Communist Soviet Union. This is not asking the universities to alter their demands for objectivity, but it is asking them to recognize that points of view which serve the political aspirations of the old imperialists should not be maintained because of their prestige alone, for they have been challenged in large part by outstanding scholars since World War I. The epigoni of the old Russian professors are by no means as sure of their ground as were their masters and it is ridiculous to suggest that no new ideas have been developed by a reworking of the old and new material. We may still be far from the time when there will be professors in the history and culture of every one of the Slavic and East European groups, in a single institution, but scholarship has advanced beyond the simple view which lumps all the 
nations of Eastern Europe into one or two convenient sections and accepts the view of the dominant nation as absolute truth.

There is, in addition, a great need for the collection and preservation of material on Slavic and Eastern Europe. At the time of World War I, the American Relief Commission under instructions from its chief, Herbert Hoover, collected enormous masses of material now preserved in the Hoover War Library at Stanford University. Slavic groups, societies and associations have brought together relatively large collections of the most valuable material that has appeared during and after World War II. Much of this material has been saved at tremendous risks, but is still scattered in various repositories, not always under ideal conditions. In addition, the libraries of American universities are becoming so crowded that they often hesitate to accept copies of works which may seem superfluous at first sight.

Thus, it would be highly desirable to form a new institution, sponsored by interested universities and the scholarly societies of the new immigration, to preserve in a convenient place, under modern library conditions, all this material. Such a project, admittedly ambitious, would require assistance from some foundation, the cooperation of all the factions among the new immigration, as well as the American institutions. Administered by a joint board, it could easily be made a center which would soon be unrivalled in the world. Even ephemeral material, such as newspapers and programs, which seem of little or no intrinsic importance, should be preserved, for in a few years they will be hotly bargained for by the greatest libraries. Why should this not now be brought together and made available for duly qualified students? Such a collection would soon prove to be more important than many apparently more valuable sources.

In the same way, perhaps under the same roof, there could be a Slavic museum not only for the major arts but also for articles of domestic use. Early immigrants brought with them home-made utensils, weavings, carpets, and dishes which now seem crude and are discarded. However, their real value is suggested by the fact that the New York State Historical Society has organized in Cooperstown an agricultural museum to preserve similar articles made in the early United States. The disappearance of the old way of life in Eastern Europe, evident even before the Communist wave of devastation and the ravages of the War, have given these articles, now in the United States 
a value far beyond anything imagined a few years ago. Some organizations such as the Polish Roman Catholic Union in Chicago, the Ukrainian Museums in Ontario, California, Chicago and Cleveland, and other groups have made small scale efforts to establish collections and libraries; some of them, such as the Shevchenko Society library, the Ukrainian Academy of Sciences library and the Hungarian Feleky library, have not yet found proper housing. There are many other small and scattered museums and collections. The development of a project on a continental scale would at once reveal the similarities and dissimilarities existing among the Slavic and East European peoples.

No single institution can possibly hope to achieve all this or to cover adequately the subjects included in a careful survey and study of Eastern Europe. Some new form of cooperation must be devised, if the burden is not to become overwhelming and thus be neglected. It cuts sharply in some respects across some of the American educational traditions but the establishments of atomic Iaboratories sponsored by several institutions, such as the Brookhaven laboratory, shows that cooperation is possible.

These, then, are but a few possibilities for future expansion of Slavic studies. The Slavic and East European studies in the United States are still in their infancy and American scholars, whether of Slavic or non-Slavic origin, have an enormous opportunity to push forward to solve many of the problems which have, until now, isolated the peoples of Eastern Europe and have barred them from playing their proper role in world affairs. 


\section{Bibliography}

Aldrich, Col. H. S. "Aims and Techniques in Language Teaching Today." (abstract) AATSEEL Bulletin, V (March, 1948), pp. 60-1.

Andrews, A. I. "University Courses Given in the United States of America on Slavic and other Eastern European History, Languages and Literature." Reprinted from Slavonic Review, 1936.

"Area Study Programs-The Soviet Union and Eastern Europe," edited by Royden Dangerfield. Institute of Government and Public Affairs, University of Illinois, 1955.

Bennett, W.C. "Area Studies in American Universities." (SSRC), Washington, 1951.

Brozek, Joseph. "Slavic Studies in America. The Present Status." Journal of Higher Education, XIV (1943), pp. 293-7.

Coleman, A. P. "The Teaching of Russian in the U.S." Russian Review, IV (Autumn, 1944), pp. 83-8.

- "The Teaching of Area and Language Courses in the Field of Slavic and East European Studies." American Slavic Review, IV (August, 1945), pp. 185-208.

- American Area and Language Courses in Slavic and East European Studies 1946-1947." American Slavic Review, V (November, 1946) pp. 162-92.

- A Report on the Status of Russian and Other Slavic and East European Languages in the Educational Institutions of the U.S." (AATSEEL) New York, 1948.

Coleman, M.M. “A Yale Man Studies Russian. James Gates Percival (1795-1856) and Russian in New Haven a Century Ago." Russian Review, VIII (April, 1949), pp. 127-34.

Coolidge, A. C. "A Plea for the Study of the History of Northern Europe." American Historical Review, II (October, 1896), pp. 34-9.

Cross, S. H. "On Teaching Contemporary Russian Civilization." Slavonic Review, XXI [American Series III] (August, 1944), pp. 93-101. 
_“Teaching College Russian,” Slavonic Review, XXII [American Series III] (October, 1944), pp. 39-52.

Czubatyj, N. D. "The Meaning of 'Russia' and 'Ukraine'." Ukrainian Quarterly, I (September, 1945), pp. 351-64.

De Francis, John, ed. Report on the Second Annual Round Table Meeting on Linguistic and Language Teaching. (Institute of Languages and Linguistics, Georgetown University, Monograph Series, No. 1, September, 1951) Washington, 1951.

Dictionary of National Biography, New York.

Dorosh, J. T. The Study and Teaching of Slavic Languages, Washington: Library of Congress, 1949.

Fenton, W. N. Area Studies in American Universities, Washington: American Council on Education, 1947.

Graves, Mortimer. "A Memorandum on Regional Studies." Journal of Higher Education, XVI (November, 1943), pp. 431-4. -A Neglected Facet of the National Security Problem. Washington, 1950.

Halecki, O. "Imperialism in Slavic and East European History." American Slavic Review, XI (February, 1952), pp. 1-26.

Hall, R. B. Area Studies: with Special Reference to Their Implications for Research in the Social Sciences. (SSRC Pamphlet No. 6) New York, 1947.

Hall, R. A., Jr. "Progress and Reaction in Modern Language Teaching." AAUP Bulletin, XXXI (Summer, 1945), pp. 22030.

Hasek, C.W. The Slavonic Languages and Literatures in American Colleges and Universities. (Higher Education Circular No. 23) Washington, 1920.

Heindel, R. H. The Present Position of Foreign Area Studies in the U.S. (SSRC) New York, 1950.

Huntington, W.C. "The Russian Translation Project Three Years Later.” Russian Review, VII (Spring, 1947), pp. 76-87.

Jacques, Agnes. "Why Students Study Russian." Modern Language Journal, XXXI (December, 1947), pp. 525-34.

Kerner, R.J. "Slavonic Studies in America." Slavonic Review, III (December, 1924), pp. 244-58. 
-“Coordination of Slavic Studies Between the Fields of the Humanities and Social Studies." AATSEEL Bulletin, VII (December, 1949), pp. 33-4.

-“Language Study and American Education." PMLA, LXVIII (September, 1953), pp. 100-16.

Manning, C.A. "The Slavonic Session of the Modern Language Association of America." Slavonic Review, IV (1926), pp. ix-x.

-"The Slavonic Group of the Modern Language Association of America." Slavonic Review, V (1927), p. vii.

-“Slavonic Studies in the United States." Modern Language Journal, XIII (1929), pp. 280-288.

- "Die slawische Wissenschaft in den Vereinigten Staaten." Osteuropa, V (1930), pp. 171-8.

-"Polish and the American Universities." Poland America, XIII (1932), pp. 489-91.

-“Modern Language Association of U.S.A. (Slavonic Group)." Slavonic Review, XI (1933), p. 521.

- "Slavonic Studies in the United States." Modern Language Journal, XIX (March, 1935), pp. 425-32.

_“American Slavonic.” American Speech, XI (1936), pp. 370-1.

_"The University and East European Cultures." Columbia University Quarterly, XXXIII (1941), pp. 242-51.

Maslenikov, O. A. "Slavic Studies in America, 1939-1946," Slavonic Review, XXV (April, 1946), pp. 528-37.

Matthews, W.K. "The Language Pattern of the U.S.S.R." Slavonic Review, XXVI (April, 1946), pp. 427-51.

Mohrenschildt, D. von. "Russian Studies in the U.S." AATSEEL Bulletin, (March, 1953), pp. 46-7.

- "Russian Area Studies and Research since World War II." Russian Review, X (April, 1953), pp. 111-19.

Nagurney, M. J. "The Teaching of Ukrainian in the U.S." American Slavic Review, IV (December, 1945), pp. 186-94.

Noyes, G. R. "Slavic Languages at the University of California." Slavonic Review, XXII [American Series, III] (October, 1944), pp. 53-60. 
Ornstein, Jacob. "A Romance Language Instructor Looks at the Slavic Languages." Modern Language Journal, XXXIII (March, 1949), pp. 185-92.

- A Decade of Russian Teaching: Notes on Methodology and Textbooks." Modern Language Journal, XXXV (April, 1951), pp. 263-79.

- Facilities and Activities of the Library of Congress in the Slavic and East European Field." American Slavic Review, XII (December, 1953), pp. 549-54.

Parry, Albert. “Teaching Russian in our Schools." Tomorrow, $\mathrm{X}$ (December, 1950), pp. 31-5.

Pei, M.A. “A Rational Program for Teaching Languages in American High Schools." American Slavic Review, IV (August, 1945), pp. 138-41.

Posin, J.A. "Russian Studies in American Colleges." Russian Review, VII (Spring, 1948), pp. 62-75.

Riazanovsky, N. V. “Old Russia, the Soviet Union, and Eastern Europe." American Slavic Review, XI (October, 1952), pp. 171-88.

Rose, W. J. Cradle Days of Slavic Studies-Some Reflections. (Slavistica No. 23) Winnipeg, 1955.

Rosenbaum, M. W. "Slavonic Studies in America." Journal of Higher Education, XVI (January, 1943), pp. 9-14.

Rosicky, Rose. A History of the Czechs (Bohemians) in Nebraska. Omaha, 1929.

-“Russian Studies at Michigan, 1908-1943." AATSEEL Bulletin, V (June, 1948), p. 85.

Schmidt, G.P. "Colleges in Ferment." American Historical Review, LIX (October, 1953), pp. 19-42.

Senn, A. "College Russian: Objectives and Methods." American Slavic Review, V (May, 1946), pp. 176-86.

- "Obstacles in the Way of Slavic Studies." AATSEEL Bulletin, VI (March, 1949), pp. 59-62.

Smal-Stocki, R. The Nationality Problem of the Soviet Union and the Russian Communist Imperialism. Milwaukee, 1952. 
Spector, Ivan. "Russian Studies in the Pacific Northwest." Slavonic Review XXII [American Series, III] (October, 1944), pp. 61-9.

Steward, J.H. Area Research: Theory and Practice. (SSRC Bulletin No. 63) New York, 1950, pp. xix and 164.

- “The Slavonic Conference at Richmond (Va)." Slavonic Review, III (March, 1925), pp. 684-93.

Tolpin, J. G. "Teaching of Scientific Russian." American Slavic Review, IV (August, 1945), pp. 158-64.

Vakar, N.P. “Teaching Russian Civilization.” AATSEEL Bulletin, VI (June, 1949), pp. 101-3.

-“Teaching Russian Civilization." AAUP Bulletin XXXV (Winter, 1949), pp. 651-60.

Wellemeyer, J. F., Jr. and M. H. North. “American Personnel in Asian, African and Eastern European Studies." [Mimeographed preliminary analysis]. (ACLS) Washington, 1953.

Wiener, Leo. "The Teaching of the Slavonic Languages." Training for Foreign Service. (U.S. Bureau of Education Bulletin No. 27) Washington, 1921, pp. 136-8.

Wiren, A. R. "The Russian Student Fund 1920-1945." Russian Review, V (Autumn, 1945), pp. 104-13.

Zenkovsky, S.A. "Periodicals in the Russian Language Program." AATSEEL Bulletin, XI (September, 1953), pp. 9-11. 


\section{Index}

Abel, Samuel, 56.

Alliance College, 39, 49, 70, 71.

American Association for the Advancement of Slavic Studies, 68.

American Association of Teachers of Slavic and East European Languages, 70 .

American Board of Commissioners for Foreign Missions, 18.

American Committee for Liberation from Bolshevism, 79.

American Council of Learned Societies, 59,75 .

American Council on Foreign Relations, 27, 50, 68 .

American Historical Association, 26, 56,70 .

American Relief Commission, 107.

American Slavic and East European Review, 68, 69, 89.

Andrews, Arthur I., 33.

Archipenko, Alexander, 49.

Armenian Review, 69.

Armstrong, Hamilton F., 27.

Armstrong, John A., 78.

Army Language School, 67.

Bachinsky; Dr., 14.

Bacon, Leonard C., 29.

Baranov, Aleksander, 6,7 .

Barta, Alois, 42.

Bender, Harold H., 33 .

Bergson, Abram, 68.

Bienowski, Count, 5.

Bilmanis, Dr., 86.

Birkenmeyer, Joseph, 60.

Bloomfield, Maurice, 25.

Bowring, Sir John, 19.

Brookings Institute, 49.

Bures, Vaclav, 40.

Burnett, Col., 59.

Burnham, Jaines, 77.

Butler, Nicholas M., 52, 62 ,

Cadet School of Warsaw, 5.

California, University of, $27,28,29$, $47,51,56,57,58,59,66,67,74$.

Cambridge University, 25.

Capek, Thomas, 58.

Carnegie Corporation, 81.

Carroll College, 21.

Chekhov Publishing House, 78.

Chicago, University of, $27,30,34$, $47,50,68,69$.

Chubaty, Nicholas, $64,69$.

Churchill, Marlborough, 46.

Chyzhevsky, Dmytro, 72 .
Clarke, James F, 79.

Cleveland Public Library, 57.

Coe College, 42.

Coleman, Arthur $P_{+}, 51,65,70$,

Colorado, University of, 68 .

Columbia University, $25,31,32,33$, $47,49,50,51,52,53,54,56,58$, $59,62,63,67,68,70,72,73$, 76,79 .

Comenius (Komensky), Jan A., 4.

Conant, Kenneth J., 54 .

Coolidge, Archibald C., 26.

Cornell University, 65.

Crane, Charles R., 30.

Creighton University, 47 .

Cressey, George B., 68.

Croatian Academy of Liberal Arts and Sciences, 72 .

Croatian National Alliance, 12.

Cross, Samuel H., 53, 54, 58, 59, 67, 68,74 .

Cundy, Percival, 92.

Curtin, Jeremiah, 21.

Czechoslovak National Alliance, 12.

Darbinian, Reuben, 69.

Dartmouth College, 48, 52, 69.

Dawson, Clarence, 56.

Denver, University of, 66 .

Deutsch, Babette, 34 .

Dobriansky, Leo, 76.

Doroshenko, Dmytro, 49.

Drizari, Nelo, 52.

Dubuque College and Seminary, 42.

Duggan, Stephan $P_{x}, 33$.

Dumbarton Oaks, 84.

Dyboski, Roman, 50.

East European Fund, Inc., 78, 105.

Ecole des Langues Orientales, Paris, 32.

Eliseeff, Serge, 48 .

Fay, Sidney B., 34.

Faymonville, Philip, 59.

Feleky Library, 108.

Fisher, H. H., 68.

Fitch, Graham D., 46.

Ford Foundation, 78,81 .

Fordhain University, 68, 72, 74.

Foreign Affairs, 27.

Foreign Language Information Service, 41 .

Francis Skorina Society (Kryvian), 71.

Franklin, Benjamin, 17.

Freiburg, University of, 26. 
Gallitzin (Golitsyn), Prince Dimitry, 6.

Gent, William, 47.

Georgetown University, 48, 57, 74, 76.

Gerschenkron, Alexander, 68.

Gilman, Pres., 25.

Golder, Frank A., 27, 30.

Golitsyn (Gallitzin), Prince Dimitry, 6.

Granovsky, Alexander, 49.

Graves, W., 59.

Haiman, Mieczyslaw, 38.

Hairenik Association, 69.

Halecki, Oskar, 64, 68, 72.

Hapgood, Isabel F., 23.

Harper, Samuel N., $30,47,55,68$.

Harvard University, 4, 6, 25, 26, 27 , $28,41,47,48,53,54,56,58,67$, $72,73,98$.

Haupt, Paul, 25.

Hayne, Frank L., 59.

Hawkes, Dean H., 53.

Hecker, Julius F., 34.

Herrman, Augustine, 4.

Heyberger, Anna, 42.

Hoover, Herbert, 107.

Hoover War Library, 56.

Hrbek, Jeffrey D., 40.

Hrbkova, Sarka B., 41, 54.

Hrdlicka, Ales, 33.

House, Edward M., 27, 34, 46.

Indiana, University of, 79.

Institute for Advanced Study, Princeton, 79.

Institute for Study of the USSR, Munich, 79.

International Baptist Seminary, 42.

Iowa, University of, $40,41,42,65$.

Jakobson, Roman, 64, 68, 73, 74.

Jaszy, Oskar, 40.

Jefferson, Thomas, 7.

Jena, University of, 33 .

Joffe, Judah A., 31 .

Johns Hopkins University, 25, 31.

Joint Committee on Slavic Studies, $68,75$.

Jones, R. W., 48.

Journal of Central European History, 69.

Journal of East European History, 69.

Karpovich, Michael, 54, 68, 74.

Kaun, Alexander, 28, 67, 74.

Kaunas, University of, 65 .

Kelly, Eric P., 48, 52.

Kennan, George, 22, 79.

Kennan, George F., 79.

Kerner, Robert J., 27, 28, 55, 68, 74.
Knizek, Charles, 42.

Kodiak, 6, 7.

Komensky (Comenius), Jan A., 4.

Komensky Educational Clubs, 40.

Kosciuszko Foundation, 50, 72 .

Kosciuszko, Tadeusz, 5, 6, 18.

Koshits, Alexander, 49.

Koukol, Alois E., 32.

Kovach, Michael, 5.

Kovalevsky, Maxim, 30.

Krakow, University of, 29, 60.

Kridl, Manfred, 64, 73.

Lafayette College, 47, 54.

Lanz, Henry, 30, 67.

Leacock, Stephen, 51.

Ledbetter, Eleanor, 57.

Lednicki, Waclaw, 64, 68, 74.

Lee, Charles, 5.

Lerando, Leon Z., 42, 47, 54.

Le Tallec, Paul, 56.

Lewis, John D., 18.

Lewis, William D., 18, 19.

Library of Congress, 56.

Lisovsky, Adm., 21.

Liverpool, University of, 30.

London, University of; School of Slavonic and East European

Studies, $30,48,52,55$.

Lord, Eric, 56.

Lord, Robert H., 28.

Magoun, Francis P., Jr., 54.

Mandell, Max S., 32, 33.

Manitoba, University of, 101

Manning, Clarence A., 32, 51, 52, $53,55,63,68,96$.

Marquette University, 72, 74.

Martinovitch, Nicholas N., 49.

Maryland, University of, 48.

Masaryk Institute, 72.

Masaryk, Thomas G., 14.

Maslenikov, Oleg, 66, 74 .

Matice Vyssoho Vzdelani, 39.

McCroskey, Benjamin B., 47.

McGill University, 51.

Meader, Clarence L., 33.

Mediaeval Academy of America, 84.

Mencken, H. L., 101.

Menges, Karl H., 53.

Menut, Albert, 65.

Michela, Joseph A., 59.

Michigan, University of, 33, 49.

Mid-European Studies Center, 79.

Milyukov, Paul, 30.

Minnesota, University of, 49.

Mirsky, Prince D. S., 52.

Mishovsky, Louis F., 39.

Missouri, University of, 55 .

Mitana, Thaddeus, 49.

Modern Language Association of America, 55, 69. 
Mogilat, Elena T., 51, 59 .

Mohrenschildt, D. von, 69.

Monroe, Will S., 33.

Morawski-Nawench, Albert, 32.

Mosely, Philip $S_{*}, 50,68$.

Murray, W. S., 33.

Myshuha, Luke, 14.

NRA, 58.

Nebraska, University of, $34,40,41$, 47.

New Jersey Normal School, Montclair, 33.

New York Public Library, 56.

New York State Historical Society, 107.

New York University, 33, 77.

Niemciewicz, Juljusz U., 6.

Notre Dame University, 40, 74.

Noyes, George R, 28, 29, 51, 55, 68.

Oberlin College, 39.

Odlozilik, Otokar, 64.

Ohio State University, 42.

Oxford University, 25.

Paderewski, Ignace J, 14.

Pares, Sir Bemard, K.B.E., 30, 55 .

Pasvolsky, Leo, 49.

Patrick, George Z., 29, 58, 59, 66, 67, 74.

Pennsylvania, University of, 65, 68 .

Percival, James G, 19.

Phelps, William Lyon, 32.

Piatkowski, Romuald, 39.

Pipal, F. J., 40.

Pisek, Rev. Vincent, 58.

Pittsburgh, University of, 54.

Poland, 56.

Polish Historical Society, 38.

Polish Institute of Arts and Sciences in America; Bulletin, 64, 71.

Polish National Alliance, 12, 39.

Polish Review, 69.

Polish Roman Catholic Union, 12, $38,108$.

Posin, Jack A, 59, 65.

Prince, John D., 31, 51, 53, 67, 94, 96.

Princeton University, 25, 33, 34.

Prokosch, B., 42.

Pulaski, Casimir, 5, 18.

Pupin, Michael 1., 14, 31, 58.

Radio Frce Europe, 79.

Radosavljevich, Paul R., 33.

Rejcha, Frank, 40.

Reshetar, John, 78.

Rezanov, Nikolay, 6, 7.

Robinson, Rev. Edward, 20.

Robinson, Geroid T., 50, 68, 73.

Rockefeller Foundation, 81 .

Rose, William J., 48.
Rosicky, John, 40.

Rostovtseff, M., 48.

Rudnyckyi, Jaroslav, 101.

Rumford, Count Benjamin T, 17.

Russian Orthodox Seminary, $4 \mathrm{~g}$.

Russian Review, 69.

St. Basil's College, 57, 71.

St. Francis Seminary, 38.

St. Mary's Seminary, 38.

St. Procopius College, 38, 57.

St. Vincent College, 38.

St. Vladimir's Russian Orthodox Seminary, 53.

Santa Barbara Mission, 3.

Schmitt, Bernadotte, 34 .

Schuyler, Eugene, 2I.

Senn, Alfred, 65, 68.

Serb National Federation, 12.

Serb National University, 72.

Seton-Watson, R. W., 55, 56.

Severa, G. F., 39.

Shelikov, Grigory, $6,7$.

Shevchenko Scientific Society, 71, $105,108$.

Shevelov, George, 72.

Shipman, A. J., 34 .

Shishmanov, Dimitar, 52.

Simek, Bohumil, 39, 40.

Simkhovich, Vladimir, 33.

Simmons, Ernest J., 53, 55, 65, 68, 73.

Slabey, Rev, Andrew, 42.

Slavic and East European Journal, 70.

Slavonic and East European Review, $55,68,89$.

Slovan Americky, 38.

Slovanska Lipa Society, 36.

Smal-Stocki, Roman, 72, 74, 77.

Smith College, 34.

Sinithsonian Institution, 33.

Social Science Research Council, 75.

Society for Advancement of Slavonic Study, 54, 55.

Southern California, University of, 57.

Spector, Ivar, 57.

Speculum, 53, 69 .

Stamoyevich, Milivoy S., 32.

Stanford University, 27, 30, 49, 56, $67,68,107$.

Stepanek, Orin, 41, 47.

Strakhovsky, Leonid I., 48, 68.

Strassburg, University of, 53 .

Struve, Gleb, 74.

Subotic, D., 52.

Syracuse University of, 65, 68 .

Talvj, 20.

Texas, University of, $42,47$.

Thomson, S. H., 68, 69 . 
Tikhon, Patriarch, 13.

Timoshenko, Stephen, 49.

Timoshenko, Volodymyr, 49.

Toronto, University of, 48 .

Tufts College, 33.

Turkevich, Rev. Leonid, 42.

Ukrainian Free Academy of Sciences, 71, 108.

Ukrainian Free University, 49, 96.

Ukrainian Museums, 108.

Ukrainian National Association, 12. $63,96$.

Ukrainian Providence Association, 12.

Ukrainian Workingmen's Association, 12.

Ukrainian Quarterly, 69.

Unbegaun, Boris, 53 .

Van Deman, Ralph, 46.

Vasilieff, A. A., 48.
Vasmer, Max, 53.

Vernadsky, George, 48, 68 .

Vienna, University of, 32 .

Vocadlo, Otakar, 52.

Walsh, Rev. Edmund, 57.

Washington, University of, 57.

White Ruthenian Institute of Arts and Sciences, 71.

Whitfield, Francis J., 68.

Wiener, Leo, 26, 27, 28, 53 .

Wisconsin, University of, $28,33,42$, 47,60 .

Yale University, 19, 21, 25, 32, 56, 68.

Yarmolinsky, Avrahm, 32, 34.

Yeaton, Ivan, 59.

Zeboroski (Zabriskie), 3.

Zenger, John Peter, 5.

Zinzendorf, Count, 4. 


\section{THE MARQUETTE SLAVIC STUDIES \\ Published by the Marquette University Press \\ Milwaukee 3, Wisconsin}

I. The Doctrine of Anarchism of Michael A. Bakunin (1955) by Eugene Pyziur.

II. Hitler's Occupation of Ukraine (1941-1944) (1956) by Ihor Kamenetsky.

III. History of Slavic Studies in the United States (1957) by Clarence A. Manning.

Available in paper or case bindings. Prices on application. 